In Cooperation with the Delaware River Basin Commission

Simulation of Runoff and Reservoir Inflow for Use in a Flood-Analysis Model for the Delaware River, Pennsylvania, New Jersey, and New York, 2004-2006

Open-File Report 2010-1014 


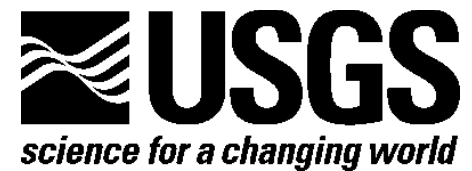

In Cooperation with the Delaware River Basin Commission

\section{Simulation of Runoff and Reservoir Inflow for Use in a Flood-Analysis Model for the Delaware River, Pennsylvania, New Jersey, and New York, 2004-2006}

By Daniel J. Goode, Edward H. Koerkle, Scott A. Hoffman, R. Steve Regan, Lauren E. Hay, and Steven L. Markstrom

Open-File Report 2010-1014

U.S. Department of the Interior U.S. Geological Survey 


\section{U.S. Department of the Interior \\ KEN SALAZAR, Secretary}

\section{U.S. Geological Survey \\ Marcia K. McNutt, Director}

U.S. Geological Survey, Reston, Virginia: 2010

For product and ordering information:

World Wide Web: http://www.usgs.gov/pubprod

Telephone: 1-888-ASK-USGS

For more information on the USGS-the Federal source for science about the Earth,

its natural and living resources, natural hazards, and the environment:

World Wide Web: http://www.usgs.gov

Telephone: 1-888-ASK-USGS

Suggested citation:

Goode, D.J., Koerkle, E.H., Hoffman, S.A., Regan, R.S., Hay, L.E., and Markstrom, S.L., 2010, Simulation of runoff and reservoir inflow for use in a flood-analysis model for the Delaware River, Pennsylvania, New Jersey, and New York, 2004-2006: U.S. Geological Survey Open-File Report 2010-1014, 68 p.

Any use of trade, product, or firm names is for descriptive purposes only and does not imply endorsement by the U.S. Government.

Although this report is in the public domain, permission must be secured from the individual copyright owners to reproduce any copyrighted material contained within this report. 


\title{
Preface
}

This report describes a model, comprised of software and data files, for hydrologic simulation of the main-stem subbasin of the Delaware River. The performance of this model has been tested on several different computer systems and configurations. Future use, however, might reveal errors that were not detected in the test simulations. Users are requested to send notification of any errors found in this report or the model to:

\author{
Director \\ USGS Pennsylvania Water Science Center \\ 215 Limekiln Road \\ New Cumberland, Pennsylvania 17070 \\ dc_pa@usgs.gov
}

The latest version of the model and this report can be obtained using the Internet address below (accessed January 2010):

http://pa.water.usgs.gov/drbfam 


\section{Contents}

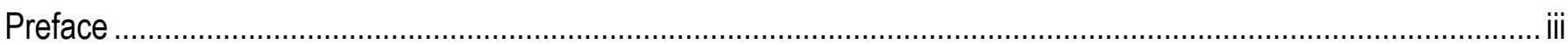

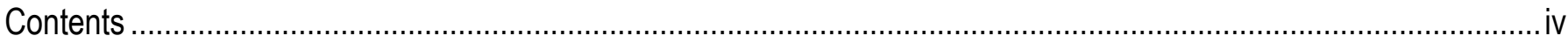

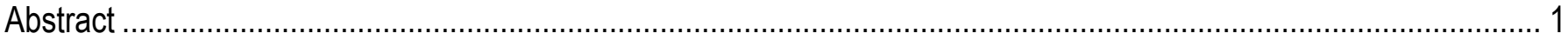

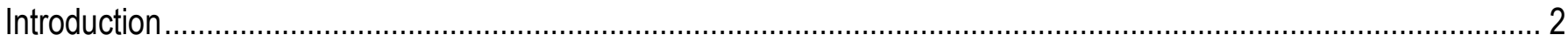

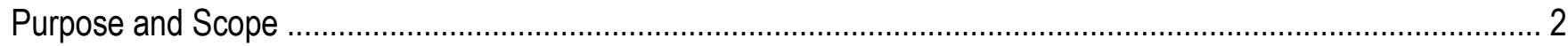

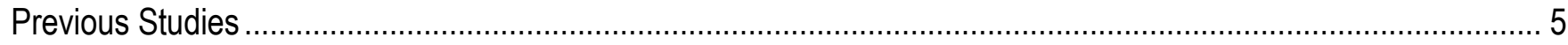

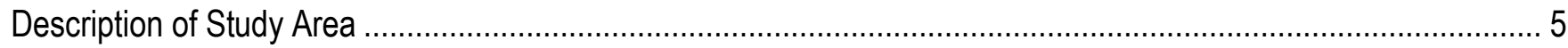

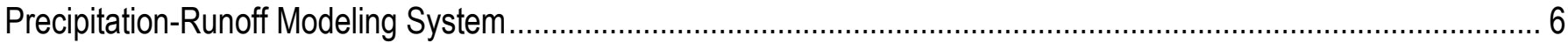

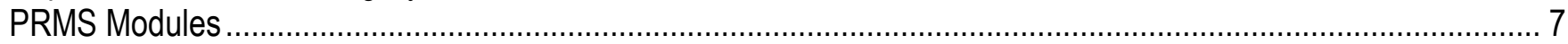

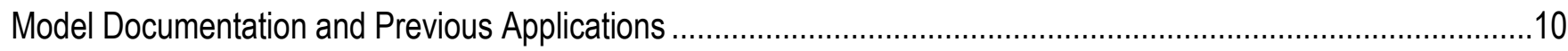

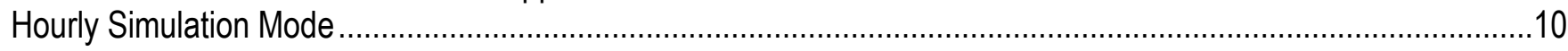

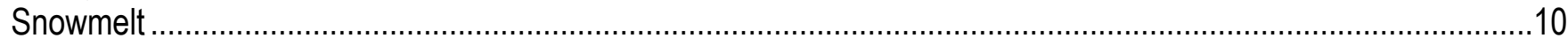

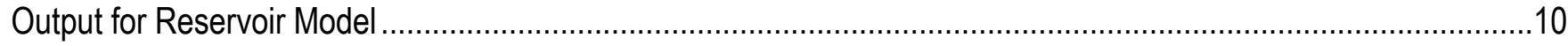

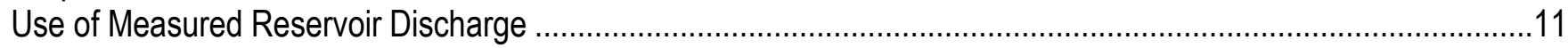

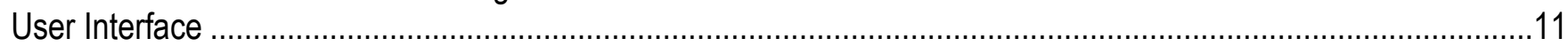

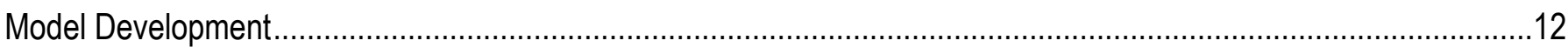

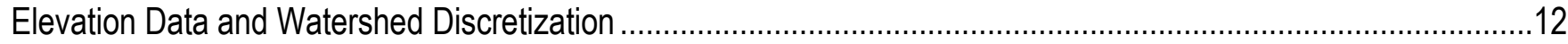

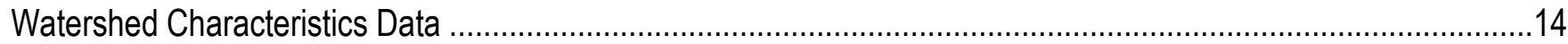

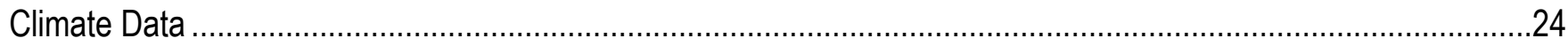

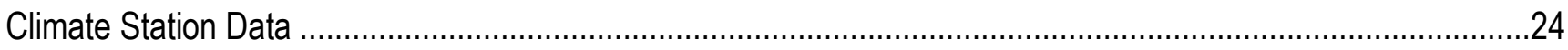

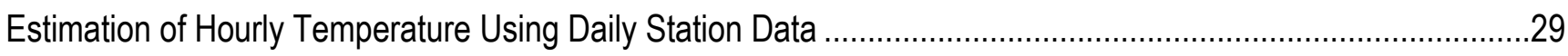

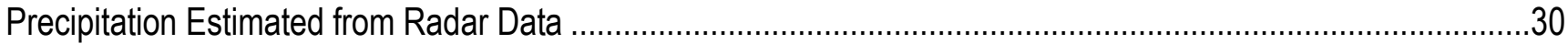

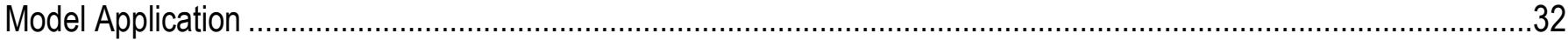

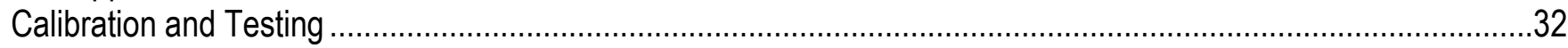

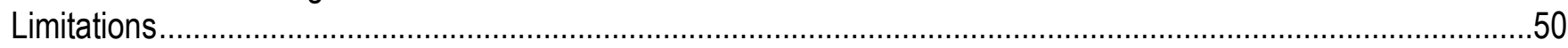

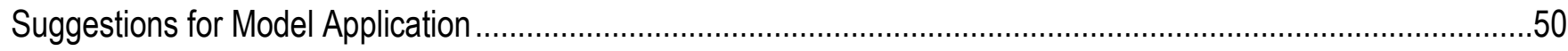

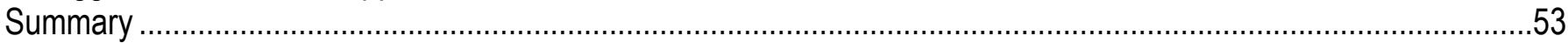

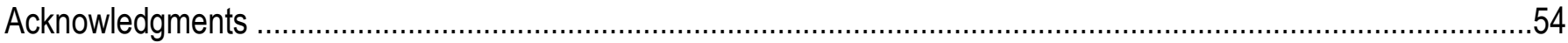

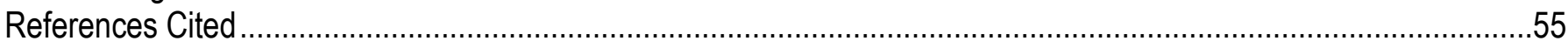

Appendix - Documentation of PRMS Modules Modified for This Study ................................................................61 


\section{Figures}

1. Location of the Delaware River main-stem subbasin and selected reservoirs, Pennsylvania, New Jersey, and

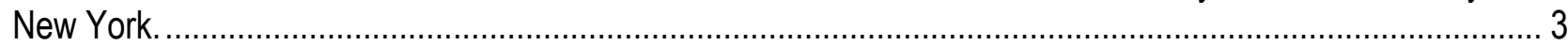

2. Location of hydrologic response units and simulated stream reaches for the Delaware River main-stem subbasin, Pennsylvania, New Jersey, and New York.....

3. Land-cover data for the Delaware River main-stem subbasin, Pennsylvania, New Jersey, and New York,

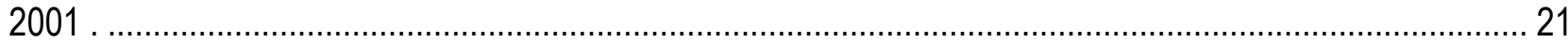

4. Impervious-surface data for the Delaware River main-stem subbasin, Pennsylvania, New Jersey, and New

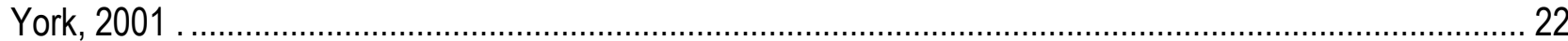

5. Mean percent impervious values for model hydrologic response units for the Delaware River main-stem subbasin, Pennsylvania, New Jersey, and New York

6. Locations of selected National Oceanic and Atmospheric Administration meteorological stations in the Delaware River main-stem subbasin, Pennsylvania, New Jersey, and New York

7. National Weather Service Multi-sensor Precipitation Estimate hourly data for 9 a.m. Eastern Standard Time on September 18, 2004, used for model data for the Delaware River main-stem subbasin, Pennsylvania, New Jersey, and New York.

8. Model hourly precipitation for 9 a.m. Eastern Standard Time on September 18, 2004, for Hydrologic Response Units for the Delaware River main-stem subbasin, Pennsylvania, New Jersey, and New York..... 31

9. Location of selected streamgages in the Delaware River main-stem subbasin, Pennsylvania, New Jersey, and New York.

10. Simulated and observed streamflow, September 13 to 26, 2004, at selected U.S. Geological Survey streamgages in the Delaware River main-stem subbasin, Pennsylvania, New Jersey, and New York. Streamflow at these locations is not regulated by reservoirs simulated in HEC-ResSim.

11. Simulated and observed streamflow, September 13 to 26, 2004, at selected U.S. Geological Survey streamgages below reservoirs in the Delaware River main-stem subbasin, Pennsylvania, New Jersey, and New York. Simulated streamflow is from HEC-ResSim reservoir and routing model using runoff and reservoir inflow from the PRMS model

12. Simulated and observed streamflow, March 26 to April 8, 2005, at selected U.S. Geological Survey streamgages in the Delaware River main-stem subbasin, Pennsylvania, New Jersey, and New York. Streamflow at these locations is not regulated by reservoirs simulated in HEC-ResSim.

13. Simulated and observed streamflow, March 26 to April 8, 2005, at selected U.S. Geological Survey streamgages below reservoirs in the Delaware River main-stem subbasin, Pennsylvania, New Jersey, and New York. Simulated streamflow is from HEC-ResSim reservoir and routing model using runoff and reservoir inflow from the PRMS model

14. Simulated and observed streamflow, June 22 to July 5, 2006, at selected U.S. Geological Survey streamgages in the Delaware River main-stem subbasin, Pennsylvania, New Jersey, and New York. Streamflow at these locations is not regulated by reservoirs simulated in HEC-ResSim.

15. Simulated and observed streamflow, June 22 to July 5, 2006, at selected U.S. Geological Survey streamgages below reservoirs in the Delaware River main-stem subbasin, Pennsylvania, New Jersey, and New York. Simulated streamflows are from HEC-ResSim reservoir and routing model using runoff and reservoir inflow from the PRMS model

16. Simulated soil-moisture saturation at noon on A) March 26, 2005, and B) June 23, 2006, for model hydrologic response units for the Delaware River main-stem subbasin, Pennsylvania, New Jersey, and New York...... 51

17. Simulated maximum runoff rate during June 22 to July 5, 2006, to model stream segments for the Delaware River main-stem subbasin, Pennsylvania, New Jersey, and New York. 


\section{Tables}

1. Selected reservoirs in the Delaware River main-stem subbasin, Pennsylvania, New Jersey, and New York... 4

2. Precipitation-Runoff Modeling System modules used for the Delaware River main-stem subbasin,

Pennsylvania, New Jersey, and New York.

3. Source of parameter values for selected model hydrologic response unit distributed parameters for the Delaware River main-stem subbasin, Pennsylvania, New Jersey, and New York

4. Selected whole-model nondistributed parameters estimated by calibration and ranges of values for the Delaware River main-stem subbasin, Pennsylvania, New Jersey, and New York

5. Selected climate stations in the Delaware River main-stem subbasin, Pennsylvania, New Jersey, and New York.

6. Solar-radiation stations used for model data for the Delaware River main-stem subbasin, Pennsylvania, New Jersey, and New York

7. Streamgages selected for use in model calibration for the Delaware River main-stem subbasin, Pennsylvania, New Jersey, and New York. 33

8. Parameters calibrated in each step of the calibration process - daily mode. 36

9. Parameters calibrated in each step of the calibration process - storm mode

10. Observed and simulated mean and standard deviation of hourly streamflow, in cubic feet per second, for streamgages used for model calibration for the Delaware River main-stem subbasin, Pennsylvania, New Jersey, and New York 
Conversion Factors, Datum, and Acronyms

\begin{tabular}{|c|c|c|}
\hline Multiply & By & To obtain \\
\hline \multicolumn{3}{|c|}{ Length } \\
\hline inch (in.) & 2.54 & centimeter $(\mathrm{cm})$ \\
\hline inch (in.) & 25.4 & millimeter $(\mathrm{mm})$ \\
\hline foot $(\mathrm{ft})$ & 0.3048 & meter $(\mathrm{m})$ \\
\hline mile (mi) & 1.609 & kilometer $(\mathrm{km})$ \\
\hline \multicolumn{3}{|c|}{ Area } \\
\hline acre & 4,047 & square meter $\left(\mathrm{m}^{2}\right)$ \\
\hline acre & 0.4047 & hectare (ha) \\
\hline square foot $\left(\mathrm{ft}^{2}\right)$ & 0.09290 & square meter $\left(\mathrm{m}^{2}\right)$ \\
\hline square inch $\left(\right.$ in $\left.^{2}\right)$ & 6.452 & square centimeter $\left(\mathrm{cm}^{2}\right)$ \\
\hline square mile $\left(\mathrm{mi}^{2}\right)$ & 259.0 & hectare (ha) \\
\hline square mile $\left(\mathrm{mi}^{2}\right)$ & 2.590 & square kilometer $\left(\mathrm{km}^{2}\right)$ \\
\hline \multicolumn{3}{|c|}{ Volume } \\
\hline gallon (gal) & 3.785 & liter $(\mathrm{L})$ \\
\hline gallon (gal) & 0.003785 & cubic meter $\left(\mathrm{m}^{3}\right)$ \\
\hline million gallons (Mgal) & 3,785 & cubic meter $\left(\mathrm{m}^{3}\right)$ \\
\hline cubic foot $\left(\mathrm{ft}^{3}\right)$ & 0.02832 & cubic meter $\left(\mathrm{m}^{3}\right)$ \\
\hline \multicolumn{3}{|c|}{ Flow rate } \\
\hline cubic foot per second $\left(\mathrm{ft}^{3} / \mathrm{s}\right)$ & 0.02832 & cubic meter per second $\left(\mathrm{m}^{3} / \mathrm{s}\right)$ \\
\hline $\begin{array}{l}\text { cubic foot per second per square mile } \\
{\left[\left(\mathrm{ft}^{3} / \mathrm{s}\right) / \mathrm{mi}^{2}\right]}\end{array}$ & 0.01093 & $\begin{array}{l}\text { cubic meter per second per } \\
\text { square kilometer }\left[\left(\mathrm{m}^{3} / \mathrm{s}\right) / \mathrm{km}^{2}\right]\end{array}$ \\
\hline gallon per minute (gal/min) & 0.06309 & liter per second $(\mathrm{L} / \mathrm{s})$ \\
\hline million gallons per day (Mgal/d) & 0.04381 & cubic meter per second $\left(\mathrm{m}^{3} / \mathrm{s}\right)$ \\
\hline inch per hour (in/h) & 0.0254 & meter per hour $(\mathrm{m} / \mathrm{h})$ \\
\hline \multicolumn{3}{|c|}{ Pressure } \\
\hline atmosphere, standard (atm) & 101.3 & kilopascal (kPa) \\
\hline bar & 100 & kilopascal (kPa) \\
\hline inch of mercury at $60^{\circ} \mathrm{F}$ (in $\mathrm{Hg}$ ) & 3.377 & kilopascal (kPa) \\
\hline pound per square inch $\left(\mathrm{lb} / \mathrm{in}^{2}\right)$ & 6.895 & kilopascal $(\mathrm{kPa})$ \\
\hline \multicolumn{3}{|c|}{ Density } \\
\hline pound per cubic foot $\left(\mathrm{lb} / \mathrm{ft}^{3}\right)$ & 16.02 & $\begin{array}{l}\text { kilogram per cubic meter } \\
\left(\mathrm{kg} / \mathrm{m}^{3}\right)\end{array}$ \\
\hline pound per cubic foot $\left(\mathrm{lb} / \mathrm{ft}^{3}\right)$ & 0.01602 & $\begin{array}{l}\text { gram per cubic centimeter } \\
\left(\mathrm{g} / \mathrm{cm}^{3}\right)\end{array}$ \\
\hline
\end{tabular}


Temperature in degrees Celsius $\left({ }^{\circ} \mathrm{C}\right)$ may be converted to degrees Fahrenheit $\left({ }^{\circ} \mathrm{F}\right)$ as follows:

${ }^{\circ} \mathrm{F}=\left(1.8 \mathrm{x}^{\circ} \mathrm{C}\right)+32$

Temperature in degrees Fahrenheit $\left({ }^{\circ} \mathrm{F}\right)$ may be converted to degrees Celsius $\left({ }^{\circ} \mathrm{C}\right)$ as follows:

${ }^{\circ} \mathrm{C}=\left({ }^{\circ} \mathrm{F}-32\right) / 1.8$

Vertical coordinate information is referenced to the North American Vertical Datum of 1988 (NAVD 88).

Horizontal coordinate information is referenced to the North American Datum of 1983 (NAD 83).

Altitude, as used in this report, refers to distance above the vertical datum.

\section{Acronyms used in this report}

$\begin{array}{ll}\text { COOP } & \text { Cooperative Climate Station } \\ \text { DEM } & \text { digital elevation model } \\ \text { DRBC } & \text { Delaware River Basin Commission } \\ \text { EST } & \text { Eastern Standard Time } \\ \text { GIS } & \text { geographic information system } \\ \text { GMT } & \text { Greenwich Mean Time } \\ \text { HEC } & \text { Hydrologic Engineering Center } \\ \text { HEC-DSS } & \text { USACE HEC Data Storage System } \\ \text { HEC-ResSim } & \text { USACE HEC Reservoir System Simulation program } \\ \text { HRU } & \text { hydrologic response unit } \\ \text { MARFC } & \text { Middle Atlantic River Forecast Center } \\ \text { MMS } & \text { Modular Modeling System } \\ \text { MPE } & \text { Multisensor Precipitation Estimate } \\ \text { NCDC } & \text { National Climatic Data Center } \\ \text { NED } & \text { National Elevation Dataset } \\ \text { NOAA } & \text { National Oceanic and Atmospheric Administration } \\ \text { NRCC } & \text { Northeast Regional Climate Center } \\ \text { NRMSE } & \text { normalized root mean square error } \\ \text { NWS } & \text { NOAA's National Weather Service } \\ \text { NYCDEP } & \text { New York City Department of Environmental Protection } \\ \text { OUI } & \text { Object User Interface } \\ \text { PRMS } & \text { Precipitation-Runoff Modeling System } \\ \text { STATSGO } & \text { State Soils Geographic Database } \\ \text { USACE } & \text { U.S. Army Corps of Engineers } \\ \text { USGS } & \text { U.S. Geological Survey }\end{array}$




\title{
Simulation of Runoff and Reservoir Inflow for Use in a Flood-Analysis Model for the Delaware River, Pennsylvania, New Jersey, and New York, 2004-2006
}

\author{
By Daniel J. Goode, Edward H. Koerkle, Scott A. Hoffman, R. Steve Regan, Lauren E. Hay, and Steven L. \\ Markstrom
}

\begin{abstract}
A model was developed to simulate inflow to reservoirs and watershed runoff to streams during three high-flow events between September 2004 and June 2006 for the main-stem subbasin of the Delaware River draining to Trenton, N.J. The model software is a modified version of the U.S. Geological Survey (USGS) Precipitation-Runoff Modeling System (PRMS), a modular, physically based, distributed-parameter modeling system developed to evaluate the impacts of various combinations of precipitation, climate, and land use on surface-water runoff and general basin hydrology. The PRMS model simulates time periods associated with main-stem flooding that occurred in September 2004, April 2005, and June 2006 and uses both daily and hourly time steps. Output from the PRMS model was formatted for use as inflows to a separately documented reservoir and riverrouting model, the HEC-ResSim model, developed by the U.S. Army Corps of Engineers Hydrologic Engineering Center to evaluate flooding. The models were integrated through a graphical user interface.

The study area is the 6,780 square-mile watershed of the Delaware River in the states of Pennsylvania, New Jersey, and New York that drains to Trenton, N.J. A geospatial database was created for use with a geographic information system to assist model discretization, determine land-surface characterization, and estimate model parameters. The USGS National Elevation Dataset at 100-meter resolution, a Digital Elevation Model (DEM), was used for model discretization into streams and hydrologic response units. In addition, geospatial processing was used to estimate initial model parameters from the DEM and other data layers, including land use. The model discretization represents the study area using 869 hydrologic response units and 452 stream segments. The model climate data for point stations were obtained from multiple sources. These sources included daily data for 22 National Weather Service (NWS) Cooperative Climate Station network stations, hourly data for 15 stations from the National Climatic Data Center, hourly data for 1 station from the NWS Middle Atlantic River Forecast Center records, and daily and hourly data for 7 stations operated by the New York City Department of Environmental Protection. The NWS Multisensor Precipitation Estimate data set for 2001-2007 was used for computing daily precipitation for the model and for computing hourly precipitation for storm simulation periods.

Calibration of the PRMS model included regression and optimization algorithms, as well as manual adjustments of model parameters. The general goal of the calibration procedure was to minimize the difference between discharge measured at USGS streamgages and the corresponding discharge simulated by the model. Daily streamflow data from 35 USGS streamgages were used in model calibration. The streamflow data represent areas draining from 20.2 to 6,780 square miles.
\end{abstract}


The PRMS model simulates reservoir inflow and watershed runoff for use as input into HECResSim for the purpose of evaluating and comparing the effects of different watershed conditions on main-stem flooding in the Delaware River watershed draining to Trenton, N.J. The PRMS model is useful as a planning tool to simulate the effects of land-use changes and different antecedent conditions on local runoff and reservoir inflow and, as input to the HEC-ResSim model, on flood flows in the main stem of the Delaware River.

\section{Introduction}

Major flooding occurred in the Delaware River Basin in September 2004, April 2005, and June 2006. To evaluate the impact of reservoir levels and other factors on flooding, the Delaware River Basin Commission (DRBC), U.S. Geological Survey (USGS), U.S. Army Corps of Engineers (USACE) Hydrologic Engineering Center (HEC), and National Oceanic and Atmospheric Administration (NOAA) National Weather Service (NWS) developed a Delaware River Flood-Analysis Model. The Flood-Analysis Model has two components, a rainfall-runoff watershed model, the PRMS model, and a reservoir operation and streamflow-routing model, the HEC-ResSim model.

\section{Purpose and Scope}

This report describes the rainfall-runoff watershed model component of the Flood-Analysis Model for the Delaware River above Trenton, N.J. The rainfall-runoff model software is a modified version of the USGS Precipitation-Runoff Modeling System (PRMS) (Leavesley and others, 1983; Leavesley and Stannard, 1995; Leavesley and others, 2005; Markstrom and others, 2008). This rainfallrunoff model simulates overland flow, groundwater flow, and streamflow to be used as inputs of reservoir inflows for 13 reservoirs (table 1, fig. 1), local inflows, and unregulated tributary flows for use in a reservoir and river routing model, the HEC-ResSim model, for the comparative analyses of different watershed conditions on main stem flows. The HEC-ResSim component of the Flood-Analysis Model is documented in a separate report. The PRMS model may be used as a planning tool to evaluate the effects of watershed conditions on runoff and, in combination with HEC-ResSim, on flows in large rivers and the main stem of the Delaware River above Trenton, N.J. during floods. The PRMS model was not developed as a forecasting tool for realtime prediction of flooding.

This report describes the software, data sources, construction, and calibration of the rainfallrunoff model of the Delaware River Basin draining to Trenton, N.J. The model simulates time periods associated with main-stem flooding that occurred in September 2004, April 2005, and June 2006. 


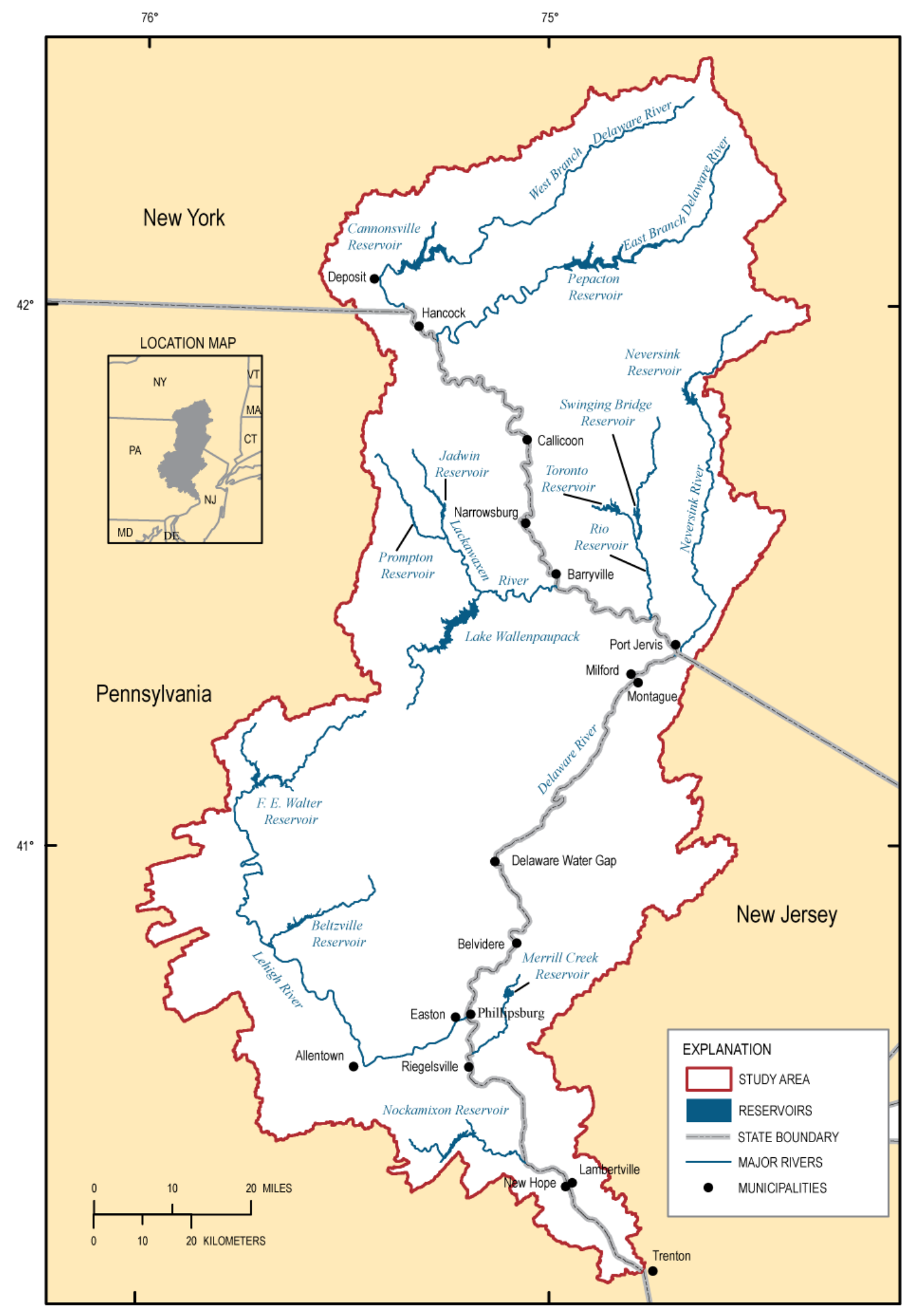

Figure 1. Location of the Delaware River main-stem subbasin and selected reservoirs, Pennsylvania, New Jersey, and New York. 
Table 1. Selected reservoirs in the Delaware River mainstem subbasin, Pennsylvania, New Jersey, and New York (data from Delaware River Basin Commission).

[FA, flow augmentation; FL, flood-loss reduction; P, hydroelectric power generation; WS, water supply; WSA, water supply primarily for flow augmentation]

\begin{tabular}{llcl}
\hline \multicolumn{1}{c}{ Reservoir } & Purpose & $\begin{array}{c}\text { Storage } \\
\text { (million gallons) }\end{array}$ & $\begin{array}{c}\text { Location } \\
\text { (stream, county, state) }\end{array}$ \\
\hline Cannonsville & WS, FA & 96,726 & West Branch Delaware River, Delaware, N.Y. \\
Pepacton & WS, FA & 143,701 & East Branch Delaware River, Delaware, N.Y. \\
Neversink & WS, FA & 35,466 & Neversink River, Sullivan, N.Y. \\
Mongaup System: Rio, Swinging Bridge, Toronto & P & 15,314 & Mongaup River, Sullivan, N.Y. \\
Lake Wallenpaupack & P & 29,813 & Wallenpaupack Creek, Wayne, Pa. \\
Prompton & FL & 6,614 & West Branch Lackawaxen River, Wayne, Pa. \\
Jadwin & FL & 7,983 & Dyberry Creek, Wayne, Pa. \\
Francis E. Walter & FL & 35,190 & Lehigh River, Luzerne and Carbon, Pa. \\
Beltzville & WSA & 12,978 & Pohopoco Creek, Carbon, Pa. \\
& FL & 8,797 & \\
Merrill Creek & WSA & 15,640 & Merrill Creek, Hunterdon, N.J. \\
Nockamixon & WS & 11,990 & Tohickon Creek, Bucks, Pa. \\
\hline
\end{tabular}

${ }^{1}$ Used for flow augmentation during drought emergencies. 


\section{Previous Studies}

A number of previous studies provide background information on the Delaware River and its watershed. Delaware River Basin Commission (2008a) summarizes the status of the watershed as of 2008, including flooding and water-supply issues. Ayers and others (1994) describe potential effects of climate change on water resources in the basin. Fischer and others (2004) assess the water quality in the basin. Sloto and Buxton (2005) compute water budgets for a small subbasin of the Delaware River where development is occurring apace. Paulachok and others (2000) describe hydrologic conditions during drought in 1998-1999. Previously, Hirsch (1981) analyzed the probabilistic impact of reservoir operations on water-resource availability during drought.

Recent flooding in the Delaware River Basin is described in several studies. Brooks (2005) describes the flood of September 18-19, 2004, in the upper Delaware River Basin. Effects of the flood of April 2005 are described by Suro and Firda (2006) for the Neversink River Basin and by Reed and Protz (2007) for the main-stem Delaware River. Suro and others (2009) describe the flooding of June 26-29 in parts of the Delaware River Basin and other basins in New York. Online summaries of flooding during June 2006 are provided by the Delaware River Basin Commission (2008b) and the U.S. Geological Survey (2008b).

The magnitude and recurrence of floods have been evaluated by many previous authors and updated as the period of record has been extended. Schopp and Firda (2008) evaluate flood frequency and magnitude for the main-stem Delaware River to Trenton, N.J., updating the statistical model of flood recurrence using data from the three recent flood events. Roland and Stuckey (2007) present flood-frequency models for selected smaller streams in the basin.

Rainfall-runoff and streamflow models have previously been developed for the study area. Flippo and Madden (1994) calibrated a streamflow-routing model for the Delaware River, with an emphasis on low-flow simulations. Chepiga and others (2004) developed a statistically based model of long-term runoff and water quality for the basin. Middle Atlantic River Forecast Center (MARFC) (2006, 2007) simulated the impact of reservoir-void changes on downstream flood levels using the NWS flood-forecast model for the Delaware River, a model used operationally for flood forecasting.

Rainfall-runoff and streamflow models have also been developed for smaller watersheds within the study area. Tolson and Shoemaker (2007) developed, calibrated, and validated a model of daily streamflow into Cannonsville Reservoir on the West Branch Delaware River. Kalin and Hantush (2006) compared the use of radar and rainfall data for modeling daily and monthly flows for the Pocono Creek watershed in Monroe County, Pa.

A daily reservoir model for the Delaware River above Trenton, OASIS (HydroLogics, Inc., 2002), has been developed to simulate reservoir releases and downstream flows. Quinodoz (2006) describes the use of OASIS to support basin management and planning. Bovee and others (2007) used OASIS to develop a model for evaluation of fish habitat in stream reaches in the upper part of the basin, including a model of stream temperature.

\section{Description of Study Area}

The study area is the watershed of the Delaware River in the states of Pennsylvania, New Jersey, and New York that drains to Trenton, N.J. (fig. 1). The watershed is delineated on the basis of the area draining to the USGS streamgage on the Delaware River at Trenton, N.J. (USGS 01463500). This is the most downstream streamgage on the main stem that is not normally affected by tides. The watershed area above the Trenton streamgage is $6,780 \mathrm{mi}^{2}$. The river length from the confluence of the West Branch Delaware River and the East Branch Delaware River at Hancock, N.Y., to Trenton, N.J., is 
approximately $200 \mathrm{mi}$. Watershed characteristics are briefly summarized in this report; additional detailed descriptions are provided by previous investigators, including Schopp and Firda (2008), Ayers and others (1994), Parker and others (1964), Fischer (1999), and Fischer and others (2004).

The Delaware River Basin has a temperate climate; seasonal and average yearly variations generally reflect variations in topography (Jenner and Lins, 1991). Average yearly temperature ranges from about $45^{\circ} \mathrm{F}$ in the north to $56^{\circ} \mathrm{F}$ in the south. Winter (December - February) monthly average temperature is slightly above freezing in the south and about $25^{\circ} \mathrm{F}$ in the north. The summer (June August) average ranges from almost $80^{\circ} \mathrm{F}$ in the south to $70^{\circ} \mathrm{F}$ in the north.

Average annual precipitation ranges from $50 \mathrm{in}$. in the north to $42 \mathrm{in}$. in the south and is typically distributed evenly throughout the year (Jenner and Lins, 1991). The number of days with precipitation generally increases from the southern to the northern part of the basin, whereas the average intensity of precipitation for days when precipitation falls generally decreases from the southern to the northern part. Variation in mean annual precipitation within the basin is primarily related to elevation changes; higher precipitation amounts are related to higher elevations (Ayers and others, 1994).

Soils, vegetation, and topography differ considerably in the basin (Parker and others, 1964). The basin lies in four physiographic provinces (Parker and others, 1964). In the southern part of the study area, the topography varies from the rolling hills of the Piedmont Physiographic Province to a series of parallel ridges, oriented northeast-southwest, in the New England Physiographic Province. These two provinces are characterized by relatively thin, clayey-loam soils, and streams respond quickly to rainfall. About one-third of the southern part of the study area is forested, primarily with hardwoods.

In the northern part of the study area, the Appalachian Plateaus and Valley and Ridge Physiographic Provinces are characterized by mountainous topography. Hillslopes are steep and covered by well-drained soils. Streamflow response to rainfall is delayed compared to the southern part of the study area. The northern part is the only part of the basin where snow accumulation is substantial in most years and the only part that once was glaciated. The northern part has numerous lakes and is mostly forested in hardwoods.

The Delaware River Basin is a vital water resource for the Nation. The daily average water use in the basin is about 4 billion gallons, more than one-half of which is for power generation. Public supply, industrial supply, and irrigation account for about 25, 15, and 1 percent, respectively, of the total water use. The Delaware River supplies large quantities of water to two of the largest metropolitan areas in the Nation-New York City and Philadelphia (Fischer and others, 2004). Approximately $620 \mathrm{Mgal} / \mathrm{d}$ is exported from the basin to New York City, and another $100 \mathrm{Mgal} / \mathrm{d}$ is exported to northeastern New Jersey. The water-management system in the basin includes many surface reservoirs used for multiple purposes, including water supply, flow augmentation, and flood mitigation (table 1). Many of these reservoirs are also used to enhance fish and wildlife habitat and increase recreational opportunities (Delaware River Basin Commission, 2008a).

\section{Precipitation-Runoff Modeling System}

The USGS PRMS (Leavesley and others, 1983; Leavesley and Stannard, 1995) software is a modular, physically based, distributed-parameter modeling system developed to evaluate the impacts of climate, topography, geology and land use on surface-water runoff and general basin hydrology. In PRMS, each component of the hydrologic system is simulated with known physical laws or empirical relations formulated on the basis of measurable watershed characteristics. The distributed-parameter and watershed-partitioning features of PRMS are designed to account for the spatial variation in watershed characteristics. The watershed is delineated into a series of contiguous spatial units, called hydrologic response units (HRUs), where the slope, land use, soil, geology, and precipitation distribution are 
similar. HRUs produce and receive flow to and from each other, to the atmosphere, and to the drainage network consisting of stream segments and lakes. Each HRU is considered homogeneous as to hydrologic response and is instantaneously and fully mixed. Areally weighted averages are computed for each characteristic that varies spatially within an individual HRU (Markstrom and others, 2008).

\section{PRMS Modules}

PRMS simulates a watershed as an interconnected series of reservoirs that represent a volume of finite capacity within each HRU. These reservoirs include water in the canopy, impervious area, snowpack, pervious portion of the soil zone - up to field capacity of the soil to rooting depth (capillary reservoir), pervious and impervious portions of the soil zone - between field capacity and total soil saturation (gravity reservoir), and water stored below the rooting zone-used to simulate groundwater flow (groundwater reservoir). The gravity reservoir can be split into two reservoirs to simulate a relatively faster interflow response (preferential flow) to a precipitation or snowmelt event that is due to the presence of macropores within the soil zone. PRMS simulates groundwater flow and storage as a combined, finite-volume series of three reservoirs - the capillary, gravity, and preferential-flow reservoirs. Flow to and from each reservoir is in the form of evaporation from the canopy and impervious areas, sublimation from the snowpack, evapotranspiration from the capillary reservoir, interflow and recharge from the gravity reservoir, and groundwater flow from the groundwater reservoir. Overland runoff is simulated on the basis of the antecedent conditions of the impervious, capillary, and gravity reservoirs. A cascading-flow procedure is used in PRMS (Markstrom and others, 2008) to simulate overland flow, interflow, and groundwater discharge in a cascading pattern between HRUs and then to the drainage network. PRMS simulates flow in the stream-channel network as the sum of inflows to each stream segment without routing when using a time step of 1 day. For hourly simulation, an implicit kinematic wave algorithm is used for streamflow routing.

The PRMS architecture consists of various user-selected modules that represent the different components of the hydrologic system and that simulate the processes associated with them. On the basis of the issues being investigated, data availability, and appropriateness of an algorithm to a particular watershed, modelers can customize PRMS by selecting the most appropriate modules for a given application. The modules selected for this study are listed in table 2 in computation order. New modules were added to PRMS for this study to 1) read preprocessed precipitation and air-temperature data by HRU, 2) generate specially formatted output for use as input to the HEC-ResSim model, and 3) simulate hourly snowpack processes using the NWS SNOW-17 model.

The PRMS modules, the HEC Data Storage System (HEC-DSS) library, and Modular Modeling System (MMS) utilities are compiled and linked to generate the model software used for rainfall-runoff simulation. PRMS modules are a group of subroutines that simulate a particular hydrologic or datahandling process. The HEC-DSS library and MMS utilities are not described in detail here. The HECDSS library (U.S. Army Corps of Engineers, Hydrologic Engineering Center, 2006) consists of a set of routines that enable retrieval and storage of input and results. The MMS utilities (Leavesley and others, 1996, 2005) are similar to the HEC-DSS library in that they provide routines to read input and write output from a model simulation. In addition, the MMS utilities provide the means to access results from modules to be input to other modules. PRMS uses the internal data structure of MMS to make input data and model states and fluxes available between PRMS modeling components. 
Table 2. Precipitation-Runoff Modeling System (PRMS) modules used for the Delaware River main-stem subbasin, Pennsylvania, New Jersey, and New York.

[HRU, hydrologic response unit; GWR, groundwater reservoir]

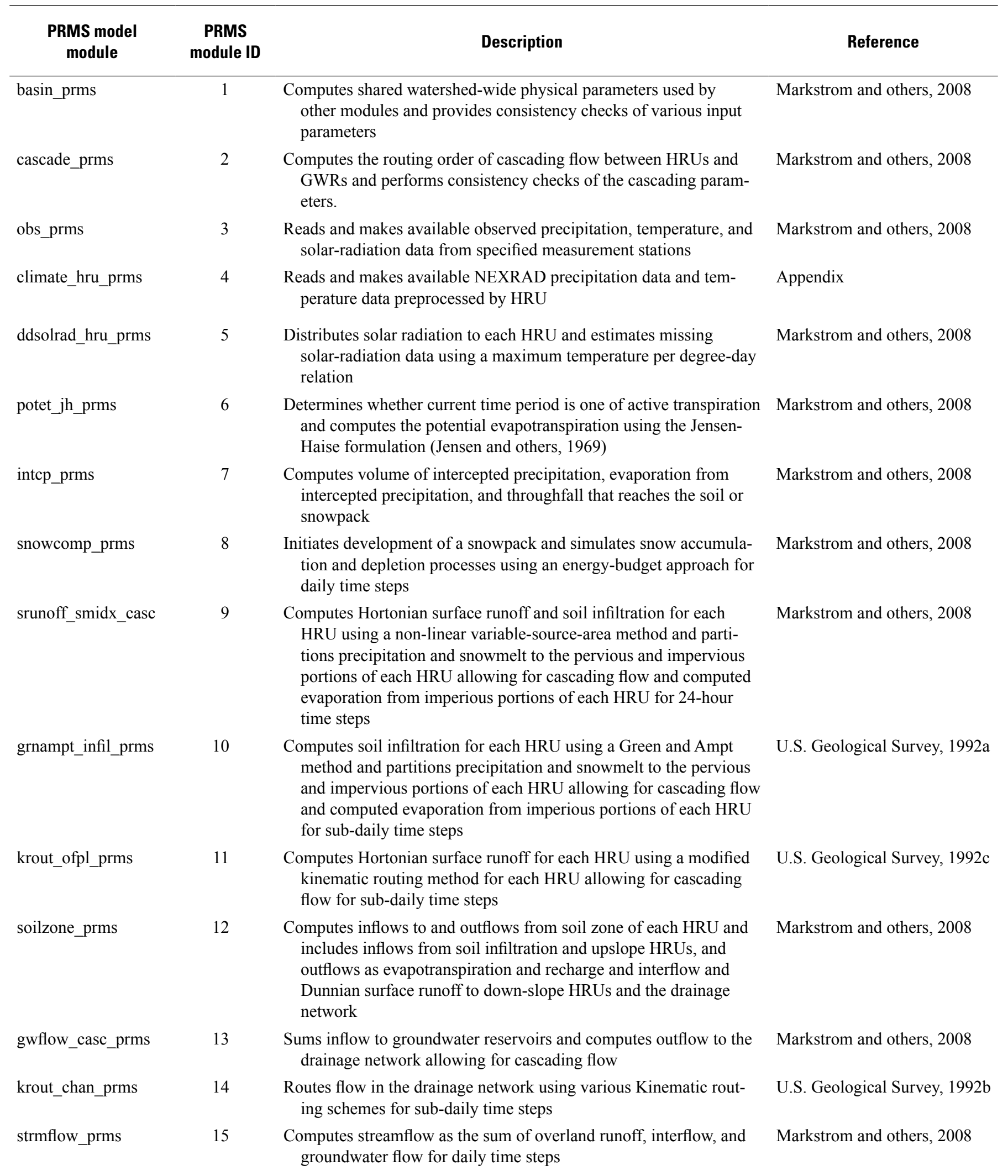


Table 2. Precipitation-Runoff Modeling System (PRMS) modules used for the Delaware River main-stem subbasin, Pennsylvania, New Jersey, and New York.-Continued

[HRU, hydrologic response unit; GWR, groundwater reservoir]

\begin{tabular}{|c|c|c|c|}
\hline subbasin_prms & 16 & $\begin{array}{l}\text { Computes streamflow as the sum of overland runoff, interflow, and } \\
\text { groundwater flow for subbasins within a watershed }\end{array}$ & U.S. Geological Survey, 2007b \\
\hline local_flow_drbc & 17 & $\begin{array}{l}\text { Sums and outputs of overland runoff, interflow, and groundwater } \\
\text { flow to hard-coded points (reservoirs and stream/river segments) } \\
\text { within the Trenton basin to an HEC DSS file for use as input to } \\
\text { HEC-ResSim. Also accumulates and outputs flows below non- } \\
\text { modeled reservoirs for use in calibration. }\end{array}$ & Apppendix \\
\hline hru_sum_prms & 18 & $\begin{array}{l}\text { Computes daily, monthly, yearly, and total flow summaries of vol- } \\
\text { umes and flows for each HRU }\end{array}$ & Markstrom and others, 2008 \\
\hline basin_sum_prms & 19 & $\begin{array}{l}\text { Sums values for daily, monthly, yearly, and total flow summaries of } \\
\text { volumes and flows for all HRUs }\end{array}$ & Markstrom and others, 2008 \\
\hline
\end{tabular}




\section{Model Documentation and Previous Applications}

Documentation for the modeling system is available in the PRMS manual (Leavesley and others, 1983) and the GSFLOW manual (Markstrom and others, 2008). GSFLOW is a coupled groundwater and surface-water flow model that uses PRMS for watershed computations. The GSFLOW manual provides the most up-to-date description for the majority of the simulation processes used in the PRMS model used in this study. PRMS and the parameterization methods used here have been used in numerous other applications, including the effects of urbanization on the spatial distribution of groundwater recharge (Vaccaro, 1992; Steuer and Hunt, 2001); water-resources management and forecasting (Fulp and others, 1995; Wilby and others, 1999; Berris and others, 2001; Mastin and Vaccaro, 2002; Hay and others, 2002; Hay and Clark, 2003; Clark and Hay, 2004; Yeung, 2005); simulation of sediment production for semi-arid watersheds (Rankl, 1987); heat and water transfer for seasonally frozen soils (Emerson, 1991); use of radar data to specify rainfall input for flood simulation (Yates and others, 2000); streamflow and wetland storage (Vining, 2002); and flow-frequency characteristics (Olson, 2002).

\section{Hourly Simulation Mode}

PRMS was used with a daily time step for simulation of antecedent conditions (daily mode) and automatically switched to an hourly time step for simulation of storms (storm mode). This approach is computationally efficient for the relatively slow changes that occur under normal conditions between storms and provides sufficient detail and flood-wave simulation during storms.

Flow routing in streams during storm mode is simulated through a kinematic wave approach (Leavesley and Stannard, 1995; Yates and others, 2000). Runoff components are cascaded from HRU to HRU in the downstream direction, until the runoff enters a stream channel or lake. Channel flow is accumulated and kinematically routed to downstream junctions and through the drainage network. The implicit finite-difference option was used for the kinematic-wave flow routing, and the module parameters were identified by calibration.

\section{Snowmelt}

PRMS uses a daily energy-balance model to compute melt and runoff from snow for daily time steps (Leavesley and others, 1983). For storm mode, PRMS was modified to use the SNOW-17 algorithm from the River Forecast System of NOAA's NWS (Anderson, 2006). This model is computationally efficient and uses hourly input data available for the study area, specifically precipitation and air temperature. This model incorporates the diurnal variation of radiation and other processes that control snowmelt through an approximate model that is based on air temperature. The basis of the SNOW-17 algorithm and its parameters are described in detail by Anderson (2006). Additional information about SNOW-17 algorithms is provided in the appendix.

\section{Output for Reservoir Model}

PRMS was modified for this study to prepare data needed for simulation of reservoirs and streamflow routing downstream of reservoirs in the watershed. The USACE HEC has developed a general-purpose reservoir-simulation model, HEC-ResSim (U.S. Army Corps of Engineers, Hydrologic Engineering Center, 2007), and has developed a reservoir model for the Delaware River. Hourly runoff

to reservoirs and local runoff to streams downstream of modeled reservoirs are computed by PRMS and used as input for HEC-ResSim. HEC-ResSim computes discharge from reservoirs and routes this flow, accumulating local runoff and tributary inflow downstream from modeled reservoirs. 
The output data provided from PRMS for use in HEC-ResSim are the time series of streamflow and local runoff into reservoirs and local runoff and tributary inflow for streams below modeled reservoirs. These PRMS output data are written to a HEC-DSS formatted file (trenton.dss). The HECDSS file format is a standard binary format developed by the HEC for storage of water-resources timeseries data and is used for input for HEC-ResSim. The HEC-DSSVue program (U.S. Army Corps of Engineers, Hydrologic Engineering Center, 2006) is available for viewing and working with data stored in HEC-DSS files. Incremental flows, which do not include flows simulated at headwater streamgages, are also provided in the DSS file for optional use with the HEC-ResSim model for simulations in which observed flows at the headwater streamgages can be used instead of simulated flows at those stations. Additional information about the modifications for preparing HEC-ResSim data is provided in the appendix.

\section{Use of Measured Reservoir Discharge}

Reservoirs in the watershed are not simulated with PRMS, because those computations are conducted in the HEC-ResSim component of the Flood-Analysis Model. However, calibration of PRMS for local flows downstream of the reservoirs is based on comparison between simulated and measured streamflow, which includes the contributions of discharges from reservoirs. PRMS was modified to use measured reservoir discharges as the upstream inflow for simulation of downstream flows. Thus, the simulated flow at downstream streamgages is a combination of the measured discharge from the reservoir, routed to the streamgage, and local flows. This procedure allowed calibration of the model parameters that control the local flows downstream of the reservoirs.

The local flows from PRMS are used as input for HEC-ResSim. However, HEC-ResSim simulates the reservoirs and produces reservoir outflows as an output of the simulation on the basis of input data controlling the operations of the reservoirs. Thus, the use of measured reservoir outflows in the PRMS model calibration does not affect the simulated outflow from reservoirs in HEC-ResSim. Additional manual calibration of PRMS used simulated downstream flows from the HEC-ResSim model to improve the flow volume match.

\section{User Interface}

User interaction with the Flood-Analysis Model is through a graphical user interface developed using the Object-User Interface (OUI) (Markstrom and Koczot, 2008). This interface allows the user to view PRMS input, to run the model components, and to view model output using a map-based scheme. The OUI software is integrated with two open-source, public-domain software packages, GeoTools (http://www.geotools.org/) sponsored by the Open Source Geospatial Foundation and National Aeronautics and Space Administration (NASA) World-wind (http://worldwind.arc.nasa.gov/java/), for geospatial processing and visualization, respectively.

The Flood-Analysis Model user interface is written using OUI and allows the user to change physical and simulation control parameters, including specifying input files and the time period for simulation, and to select output written to files and graphs. A brief guide to the user interface for the Flood-Analysis Model is provided online at http://pa.water.usgs.gov/drbfam. More detailed instructions on the functionality and customization of OUI are provided by Markstrom and Koczot (2008). 


\section{Model Development}

The PRMS model consists of the software, described in the previous section, and data input required for rainfall-runoff simulation. This section describes the procedures used to prepare input for, or parameterize, PRMS.

A geospatial database was created for use with a geographic information system (GIS) to assist model discretization, to determine land-surface characterization, and to estimate PRMS model parameters. The combination of the GIS database and standard spatial processing techniques, similar to previously modeled watersheds (Battaglin and others, 1993; Jeton, 2000; Jeton and others, 1996), allowed the spatial variations of basin characteristics to be documented and objectively analyzed. All data sets in the database are in the same Cartesian coordinate system: Universal Transverse Mercator (UTM), zone 18 with NAD 83 as the horizontal control datum.

\section{Elevation Data and Watershed Discretization}

Topography, or altitude change on the land surface, is a primary factor in the distribution and rates of surface runoff. Hence, a primary input for PRMS is a digital elevation model (DEM) of the study area. For this study, the USGS National Elevation Dataset (NED) (U.S. Geological Survey, 2007a) at 100-m resolution was used for the Delaware River Basin draining to Trenton, N.J. The DEM was pre-processed to specify locally low elevations at known stream locations in order to improve the match between known stream locations and those generated by automatic processing of the DEM.

A PRMS model uses the concept of partitioning a watershed into spatial units on the basis of watershed characteristics such as elevation, slope, aspect, vegetation type, soil type, land use, and precipitation distribution. Initially, the watershed is delineated into stream segments with a minimum flow accumulation as determined by a GIS analysis. The DEM was processed using automated techniques suggested by the GIS Weasel (Viger and Leavesley, 2007) to create flow-direction and flowaccumulation raster data sets that produced an artificial stream raster on the basis of a selected maximum number of contributing cells that totaled approximately $15 \mathrm{mi}^{2}$. This stream raster was manually edited to include selected elevation breaks in the DEM using analytical hillshading as a guide. These stream segments were then edited to represent the points at which runoff can be calibrated, at selected USGS streamgage locations. The stream network was also split by the outline of the 13 simulated reservoirs and where very long stream segments might produce instability in computing streamflow using the implicit, finite-difference kinematic routing scheme used for sub-daily stream routing.

An iterative procedure was used to discretize the watershed into HRUs and link those HRUs to a computational stream network. HRUs were initially generated using the DEM for the study area. The edited stream raster was then used to delineate the initial stream-segment contributing areas, or oneplane HRUs. The separate contributing surface areas to the left and right bank of each stream segment, two-plane HRUs, are required for storm-mode streamflow routing. These two-plane HRUs were created by using the stream raster and the DEM to determine the longest flow path to split the one-plane HRU into left- and right-bank drainages. After two-plane HRUs were converted from raster-format data into vector-format data, a spatial-join process was used to combine the reservoir polygons with the twoplane HRUs. A map of the reservoirs was overlain on the original HRUs, and simulated reservoirs were treated as a special type of HRU, a lake HRU. Manual editing was done as the final step to remove

small-area HRUs or merge them into an adjacent, hydrologically similar HRU. The PRMS model of the Delaware above Trenton is composed of 869 HRUs and 452 stream segments (fig. 2). 


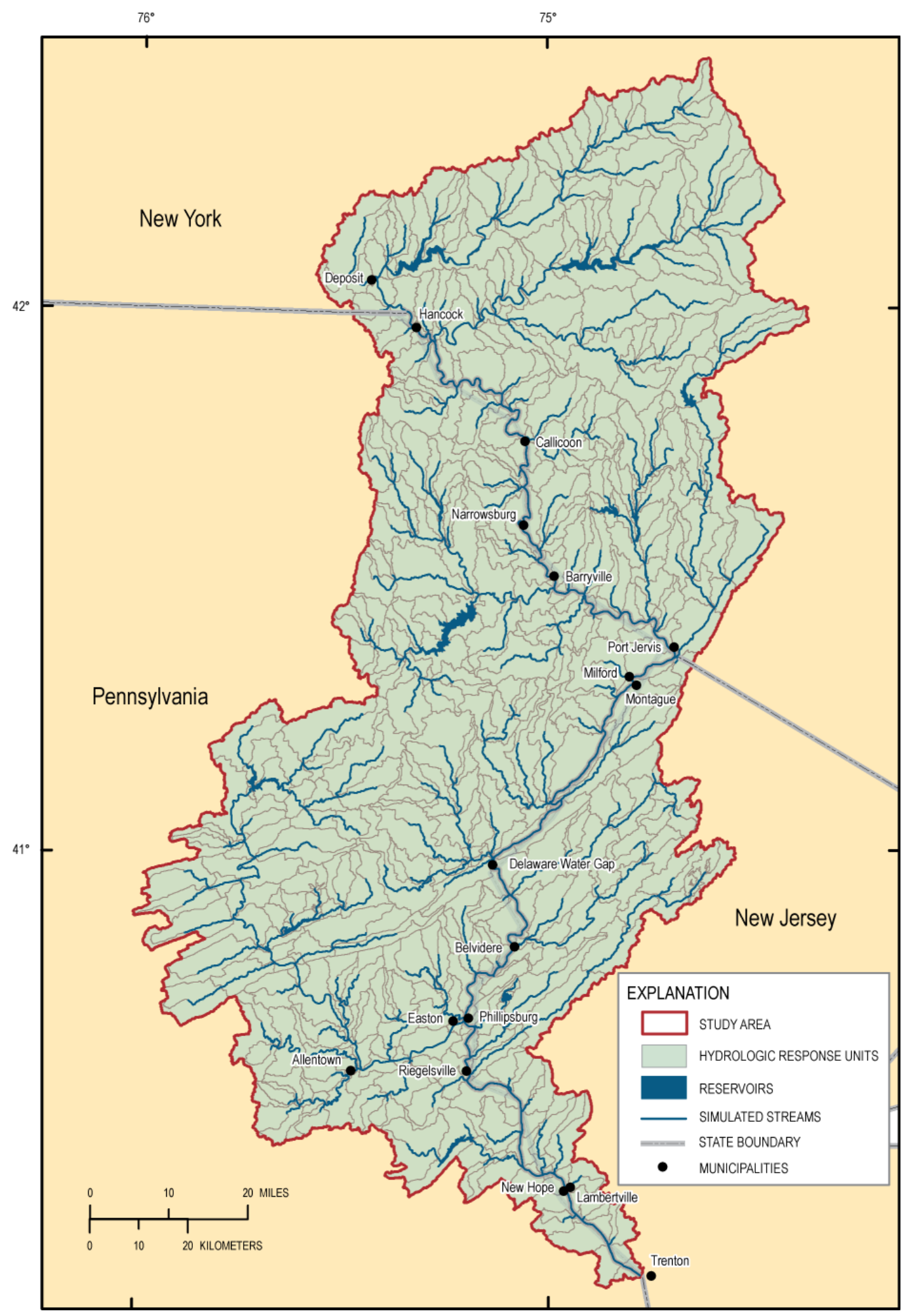

Figure 2. Location of hydrologic response units and simulated stream reaches for the Delaware River main-stem subbasin, Pennsylvania, New Jersey, and New York. 
The GIS Weasel also determined HRU-specific indices describing connectivity of HRUs with the stream network. The HRU responses were grouped by stream segments specific to each subbasin, and flow was routed through the stream-segment units in a downstream order, enabling output from the model to provide estimates of flow at any stream segment.

\section{Watershed Characteristics Data}

PRMS model parameters related to watershed properties controlling runoff were assigned to the discretized model, HRUs and streams, by processing available GIS coverages of soils, elevation, geology, land use, and other characteristics. These initial parameters were subsequently adjusted, in some cases, during model calibration. The parameterization methods used include those documented by Viger and Leavesley (2007), Battaglin and others (1993), Jeton (2000), and Koczot and others (2005). Additional selected parameterization methods recently developed for modeling runoff in Connecticut were also used (D.M. Bjerklie, U.S. Geological Survey, written commun., May 11, 2009).

Digital spatial data were collected for the study in raster format (a gridded data structure made of rows and columns) and vector format (discrete coordinates that can be used as points or connected to create lines and polygons). The digital data included elevation, generalized geology, land cover, and soils. The sources for the spatial data included the USGS NED for elevation (U.S. Geological Survey, 2007a) where slope and aspect calculations were derived using GIS software ArcGIS version 9.2; state geology data from New Jersey (New Jersey Department of Environmental Protection, 1996), New York (New York State Museum/New York Geological Survey, 1999), and Pennsylvania (Pennsylvania Department of Conservation and Natural Resources, 2001); land cover and impervious surface data from the 2001 National Land Cover Database (Multi-Resolution Land Characteristics Consortium, 2001); and soils data originally from the State Soil Geographic (STATSGO) Database (Soil Survey Staff, 1994; Natural Resources Conservation Service, 2006) and further processed with value-added soil characteristics (Miller and White, 1998). Selected reclassification tables (Viger and Leavesley, 2007) were used with land-cover data to assist in refining the HRU characteristics. The sources of values for selected distributed PRMS model parameters are described in table 3, along with ranges of values used. Nondistributed parameters that apply to the entire model are described in table 4. 
Table 3. Source of parameter values for selected model hydrologic response unit (HRU) distributed parameters for the Delaware River main-stem subbasin, Pennsylvania, New Jersey, and New York (modified from Jeton, 2000; Koczot and others, 2005).

[CAL, parameters that (a) cannot be estimated from available data and are adjusted during calibration or (b) have initial estimates from measured or published data that were adjusted during calibration; DEF, parameters that are considered constant, as provided by Leavesley and others (1983); LIT, obtained from the literature as estimated or empirical estimates (Black, 1996, table 4-1, p. 93); GIS, computed in geographic information system from digital coverages; COM, computed from climatological data or other measured data]

\begin{tabular}{|c|c|c|c|c|}
\hline Model parameter & Description of model parameter & Range of values & $\begin{array}{c}\text { Source of } \\
\text { values }\end{array}$ & $\begin{array}{c}\text { PRMS } \\
\text { module ID' }\end{array}$ \\
\hline carea_max & $\begin{array}{l}\text { Maximum area contributing to surface runoff } \\
\text { (decimal percent) }\end{array}$ & $0.036-0.796$ & CAL & 9 \\
\hline chan_alpha & $\begin{array}{l}\text { Kinematic routing parameter " } a \text { " for each channel } \\
\text { segment }\end{array}$ & $0.076-0.693$ & CAL & 14 \\
\hline chan_cmp & $\begin{array}{l}\text { Kinematic routing parameter " } m \text { " for each chan- } \\
\text { nel segment }\end{array}$ & 1.67 & DEF & 14 \\
\hline cov_type & $\begin{array}{l}\text { Vegetation cover type (developed-water-open, } \\
\text { grasses-shrubs, mixed forest, coniferous forest) }\end{array}$ & $\begin{array}{l}\text { Developed-water-open, } \\
\text { grasses-shrubs, mixed for- } \\
\text { est, coniferous forest }\end{array}$ & GIS & $7,8,12$ \\
\hline covden_sum & $\begin{array}{l}\text { Vegetation cover density for summer (decimal } \\
\text { percent) }\end{array}$ & $0-1.0$ & GIS & $7,8,12,18$ \\
\hline fastcoef_lin & $\begin{array}{l}\text { Linear coefficient in downslope routing equation } \\
\text { for preferential-flow storage }\left(\text { day }^{-1}\right)\end{array}$ & $0.0048-0.1061$ & $\mathrm{COM}$ & 12 \\
\hline fastcoef_sq & $\begin{array}{l}\text { Non-linear coefficient in downslope routing equa- } \\
\text { tion for preferential-flow storage }\end{array}$ & 0.80 & DEF & 12 \\
\hline ground_melt & $\begin{array}{l}\text { Daily rate of snowmelt at the snowpack-ground } \\
\text { interface (millimeters per day) }\end{array}$ & 0 & DEF & 8 \\
\hline gwflow_coef & $\begin{array}{l}\text { Groundwater routing coefficient to obtain the } \\
\text { groundwater flow contribution to streamflow } \\
\left(\text { day }^{-1}\right)\end{array}$ & $0.01-0.05$ & CAL & 13 \\
\hline hru_deplcrv & Index number for snowpack depletion curve & 1 & DEF & 8 \\
\hline hru_percent_imperv & $\begin{array}{l}\text { Portion of HRU area that is impervious (decimal } \\
\text { percent) }\end{array}$ & $0-0.43$ & GIS & $1,8,18$ \\
\hline imperv_stor_max & $\begin{array}{l}\text { Maximum impervious retention storage for the } \\
\text { HRU (inches) }\end{array}$ & $0.135-2.83$ & GIS & 9,10 \\
\hline jh_coef_hru & $\begin{array}{l}\text { Air-temperature coefficient used in the Jensen } \\
\text { and Haise (1963) potential-evapotranspiration } \\
\text { computations for each HRU }\end{array}$ & $16.2-18.7$ & $\mathrm{COM}$ & 6 \\
\hline kpar & $\begin{array}{l}\text { Hydraulic conductivity of the transmission zone } \\
\text { (inches per hour) }\end{array}$ & $1.53-5.00$ & CAL & 10 \\
\hline melt_base & $\begin{array}{l}\text { Base temperature used in calculation of snowmelt } \\
\text { during periods of no rain (degree Celsius) }\end{array}$ & 0 & DEF & 8 \\
\hline
\end{tabular}


Table 3. Source of parameter values for selected model hydrologic response unit (HRU) distributed parameters for the Delaware River main-stem subbasin, Pennsylvania, New Jersey, and New York (modified from Jeton, 2000; Koczot and others, 2005).—Continued

[CAL, parameters that (a) cannot be estimated from available data and are adjusted during calibration or (b) have initial estimates from measured or published data that were adjusted during calibration; DEF, parameters that are considered constant, as provided by Leavesley and others (1983); LIT, obtained from the literature as estimated or empirical estimates (Black, 1996, table 4-1, p. 93); GIS, computed in geographic information system from digital coverages; COM, computed from climatological data or other measured data]

\begin{tabular}{|c|c|c|c|c|}
\hline Model parameter & Description of model parameter & Range of values & $\begin{array}{l}\text { Source of } \\
\text { values }\end{array}$ & $\begin{array}{c}\text { PRMS } \\
\text { module ID' }\end{array}$ \\
\hline mf_max & $\begin{array}{l}\text { Annual maximum factor in snowmelt cycle } \\
\text { (millimeters per degree Celsius per day ) }\end{array}$ & $0.50-7.94$ & CAL & 8 \\
\hline mf_min & $\begin{array}{l}\text { Annual minimum factor in snowmelt cycle } \\
\text { (millimeters per degree Celsius per day) }\end{array}$ & $0.13-3.99$ & CAL & 8 \\
\hline negmf_max & $\begin{array}{l}\text { Maximum negative snowmelt factor } \\
\text { (millimeters per degree Celsius per day) }\end{array}$ & 0.6 & DEF & 8 \\
\hline ofp_alpha & $\begin{array}{l}\text { Kinematic routing parameter "a" for overland } \\
\text { flow plane }\end{array}$ & 0.003 & DEF & 11 \\
\hline ofp_cmp & $\begin{array}{l}\text { Kinematic routing parameter " } \mathrm{m} \text { " for overland } \\
\text { flow plane }\end{array}$ & 1.67 & DEF & 11 \\
\hline ofp_impv_alpha & $\begin{array}{l}\text { Kinematic routing parameter "a" for impervious } \\
\text { overland flow }\end{array}$ & 2.0 & DEF & 11 \\
\hline ofp_thresh & $\begin{array}{l}\text { Minimum depth of flow to continue overland flow } \\
\text { routing (inches) }\end{array}$ & 0.00001 & CAL & 11 \\
\hline pref_flow_den & Preferential-flow pore density (decimal percent) & $0-0.127$ & GIS & 12 \\
\hline psp & $\begin{array}{l}\text { Product of moisture deficit and capillary drive for } \\
\text { soil recharge equal to field capacity (inches) }\end{array}$ & $5.208-24.997$ & CAL & 10 \\
\hline rad_trncf & $\begin{array}{l}\text { Transmission coefficient for short-wave radiation } \\
\text { through the winter canopy (decimal percent) }\end{array}$ & $0.196-0.935$ & $\mathrm{COM}$ & 8 \\
\hline rain_sub_adj & Monthly adjustment to rainfall by subbasin & $0.6-3.0$ & CAL & 4 \\
\hline $\operatorname{rgf}$ & $\begin{array}{l}\text { Ratio of psp at field capacity to psp at wilting } \\
\text { point }\end{array}$ & 9.5 & DEF & 10 \\
\hline smidx_coef & $\begin{array}{l}\text { Coefficient in the nonlinear contributing area } \\
\text { algorithm computing surface runoff (decimal } \\
\text { fraction) }\end{array}$ & $0.0001-0.8473$ & CAL & 9 \\
\hline smidx_exp & $\begin{array}{l}\text { Exponent in nonlinear contributing area algorithm } \\
\text { computing surface runoff }\left(\text { inch }^{-1}\right)\end{array}$ & $0.205-0.787$ & CAL & 9 \\
\hline snarea_thresh & $\begin{array}{l}\text { Maximum snow water equivalent below which } \\
\text { the snow-covered area depletion curve is ap- } \\
\text { plied (inches) }\end{array}$ & $0.075-7.490$ & $\mathrm{COM}$ & 8 \\
\hline snow_intcp & $\begin{array}{l}\text { Snow interception storage capacity for the major } \\
\text { vegetation type on an HRU (inches) }\end{array}$ & $0.00047-0.06673$ & GIS & 7 \\
\hline snow_sub_adj & Monthly adjustment to snowfall by subbasin & $1.0-2.875$ & CAL & 4 \\
\hline
\end{tabular}


Table 3. Source of parameter values for selected model hydrologic response unit (HRU) distributed parameters for the Delaware River main-stem subbasin, Pennsylvania, New Jersey, and New York (modified from Jeton, 2000; Koczot and others, 2005).—Continued

[CAL, parameters that (a) cannot be estimated from available data and are adjusted during calibration or (b) have initial estimates from measured or published data that were adjusted during calibration; DEF, parameters that are considered constant, as provided by Leavesley and others (1983); LIT, obtained from the literature as estimated or empirical estimates (Black, 1996, table 4-1, p. 93); GIS, computed in geographic information system from digital coverages; COM, computed from climatological data or other measured data]

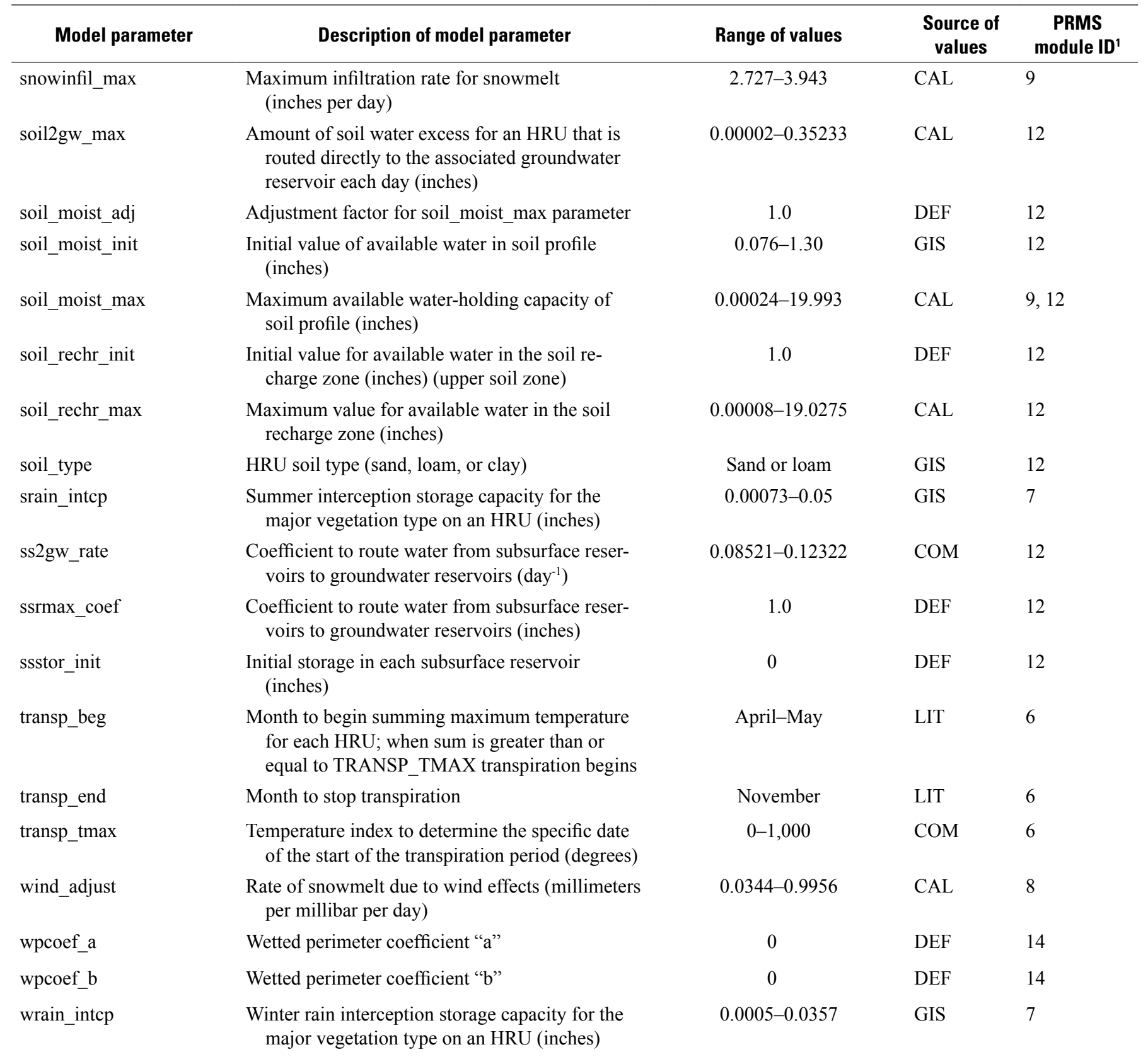

${ }^{1}$ PRMS modules are listed on table 2. 
Table 4. Selected whole-model nondistributed parameters estimated by calibration and ranges of values for the Delaware River main-stem subbasin, Pennsylvania, New Jersey, and New York (modified from Jeton, 2000; Koczot and others, 2005).

[DEF, parameters that are considered constant, as provided by Leavesley and others (1983); LIT, obtained from the literature as estimated or empirical estimates (Black, 1996, table 4-1, p. 93); CAL, parameters that (a) cannot be estimated from available data and are adjusted during calibration or (b) have initial estimates from measured or published data that were adjusted during calibration; ET, evapotranspiration; HRU, hydrologic response unit]

\begin{tabular}{|c|c|c|c|c|}
\hline $\begin{array}{c}\text { Model } \\
\text { parameter }\end{array}$ & Description of model parameter & Range of values & $\begin{array}{c}\text { Source of } \\
\text { values }\end{array}$ & $\begin{array}{c}\text { PRMS } \\
\text { module ID }\end{array}$ \\
\hline albset_rna & $\begin{array}{l}\text { Proportion of rain in a rain-snow event above which the snow albedo is } \\
\text { not reset; snowpack accumulation stage (decimal percent) }\end{array}$ & 0.8 & $\mathrm{DEF}$ & 8 \\
\hline albset_rnm & $\begin{array}{l}\text { Proportion of rain in a rain-snow event above which the snow albedo is } \\
\text { not reset; snowpack melt stage (decimal percent) }\end{array}$ & 0.6 & DEF & 8 \\
\hline albset_sna & $\begin{array}{l}\text { Minimum snowfall, in water equivalent, needed to reset snow albedo dur- } \\
\text { ing the snowpack accumulation stage (inches) }\end{array}$ & 0.05 & DEF & 8 \\
\hline albset_snm & $\begin{array}{l}\text { Minimum snowfall, in water equivalent, needed to reset snow albedo dur- } \\
\text { ing the snowpack melt stage (inches) }\end{array}$ & 0.2 & DEF & 8 \\
\hline cecn_coef & $\begin{array}{l}\text { Monthly convection condensation coefficient } \\
\text { (calories per degree Celsius above } 0 \text { degrees Celsius) }\end{array}$ & 5.0 & DEF & 8 \\
\hline chan_chi & $\begin{array}{l}\text { Finite difference weighting factor for each channel segment (decimal } \\
\text { percent) }\end{array}$ & 0.6 & DEF & 14 \\
\hline dday_slope & $\begin{array}{l}\text { Monthly slope in degree-day relation when estimating potential solar } \\
\text { radiation (degree-days per degree) }\end{array}$ & $0.31-0.65$ & LIT & 5 \\
\hline den_init & Initial density of new-fallen snow (grams per cubic centimeter) & 0.1 & DEF & 8 \\
\hline den_max & Average maximum density of snowpack (grams per cubic centimeter) & 0.6 & DEF & 8 \\
\hline emis_noppt & Average emissivity of air on days without precipitation & 0.757 & DEF & 8 \\
\hline freeh2o_cap & Free-water holding capacity of snowpack & 0.05 & DEF & 8 \\
\hline ground_melt & $\begin{array}{l}\text { Daily rate of snow melt at the snowpack_ground interface } \\
\text { (millimeters per day) }\end{array}$ & 0 & DEF & 8 \\
\hline mf_curve & Monthly snowmelt curve factor & 0.5 & DEF & 8 \\
\hline ofp_chi & Finite difference weighting factor for overland flow routing & 0.6 & DEF & 11 \\
\hline ofp_theta & Finite-difference spatial weighting factor for overland flow routing & 0.5 & DEF & 11 \\
\hline potet_sublim & Proportion of potential ET sublimated from snow surface & 0.75 & CAL & 7,8 \\
\hline potet_sublim_st & Proportion of potential ET sublimated from snow surface in storm mode & 0.75 & DEF & 8 \\
\hline ppt_rad_adj & Solar radiation reduced if precipitation exceeds this value (inches) & 0.02 & DEF & 5 \\
\hline radadj_intcp & Intercept in temperature-solar radiation relation (degree-day) & 1 & DEF & 5 \\
\hline radadj_slope & Slope in temperature-solar radiation relation (degree-day per degree) & 0 & DEF & 5 \\
\hline radj_sppt & $\begin{array}{l}\text { Adjustment factor for computed summer solar radiation when precipita- } \\
\text { tion is greater than ppt_rad_adj }\end{array}$ & 0.44 & DEF & 5 \\
\hline radj_wppt & $\begin{array}{l}\text { Adjustment factor for computed winter solar radiation when precipitation } \\
\text { is greater than ppt rad adj }\end{array}$ & 0.5 & DEF & 5 \\
\hline
\end{tabular}


Table 4. Selected whole-model nondistributed parameters estimated by calibration and ranges of values for the Delaware River main-stem subbasin, Pennsylvania, New Jersey, and New York (modified from Jeton, 2000; Koczot and others, 2005).-Continued

[DEF, parameters that are considered constant, as provided by Leavesley and others (1983); LIT, obtained from the literature as estimated or empirical estimates (Black, 1996, table 4-1, p. 93); CAL, parameters that (a) cannot be estimated from available data and are adjusted during calibration or (b) have initial estimates from measured or published data that were adjusted during calibration; ET, evapotranspiration; HRU, hydrologic response unit]

\begin{tabular}{|c|c|c|c|c|}
\hline $\begin{array}{c}\text { Model } \\
\text { parameter }\end{array}$ & Description of model parameter & Range of values & $\begin{array}{c}\text { Source of } \\
\text { values }\end{array}$ & $\begin{array}{c}\text { PRMS } \\
\text { module ID' }\end{array}$ \\
\hline radmax & $\begin{array}{l}\text { Maximum portion of potential solar radiation that reaches ground after } \\
\text { atmospheric interferences (haze, dust, smog, etc.) (decimal percent) }\end{array}$ & 0.8 & DEF & 5 \\
\hline rain_min & $\begin{array}{l}\text { Minimum rainfall rate triggering rain-on-snow melt estimates } \\
\text { (millimeters per hour) }\end{array}$ & 0.25 & DEF & 8 \\
\hline settle_constant & Snowpack settlement time constant & 0.1 & DEF & 8 \\
\hline snarea_curve & Snow area depletion curves values & $0.05-1.0$ & CAL & 8 \\
\hline sntemp_thresh & $\begin{array}{l}\text { Threshold snowfall rate above which the temperature index of snowpack } \\
\text { is reset to temperature of new snowfall (millimeters per hour) }\end{array}$ & 1.5 & DEF & 8 \\
\hline tmax_allrain & $\begin{array}{l}\text { Precipitation all rain if maximum HRU temperature is equal to or greater } \\
\text { than this monthly value (degrees) }\end{array}$ & 44 & CAL & 5 \\
\hline tmax_allsnow & $\begin{array}{l}\text { Precipitation all snow if maximum HRU temperature is equal to or less } \\
\text { than this value (degrees) }\end{array}$ & 32 & DEF & 8 \\
\hline tmax_index & $\begin{array}{l}\text { Index temperature used to determine precipitation adjustments to solar } \\
\text { radiation (degrees) }\end{array}$ & $30-70$ & CAL & 5 \\
\hline tstorm_mo & Months when convective storms are prevalent & May-Sept & LIT & 8 \\
\hline
\end{tabular}

${ }^{1}$ PRMS modules are listed on table 2. 
The PRMS parameter hru_percent_imperv, the HRU impervious surface as a decimal percent of the total HRU area, is determined using GIS processing of the land cover and impervious area data sets. The land cover and impervious surface for the study area are shown in figures 3 and 4, and the resultant hru_percent_imperv values assigned to each HRU are shown in figure 5. The HRU value of the parameter is the average percent impervious for each of the land-cover rasters that fall within the HRU polygon, scaled by a factor to account for isolated impervious areas that drain to pervious areas, and do not directly contribute to rapid runoff. The scale factor yields an effective impervious surface area that is less than the actual area, with a smaller reduction for "urban" HRUs where the actual impervious area is larger than 10 percent. The scale factor formulae were determined by analysis of storm runoff in Connecticut by Bjerklie and others (D.M. Bjerklie, U.S. Geological Survey, written commun., 2008) and from previous studies (Alley and Veenhuis, 1983; Sutherland, 1995, 2005). The land-cover data set was used for verification, adjusting impervious area where the land cover is not developed, and was used for estimation of other parameters, such as those controlling evapotranspiration. Similar procedures were used for determining initial values of other model parameters from raster data sets.

The PRMS model includes storm-mode simulation and, hence, includes cascading of runoff from HRU to HRU, eventually to stream segments and lakes, and flow routing in stream segments. Markstrom and others (2008, p. 33-34) describe the model parameters controlling cascading, which were identified through calibration for this study. 


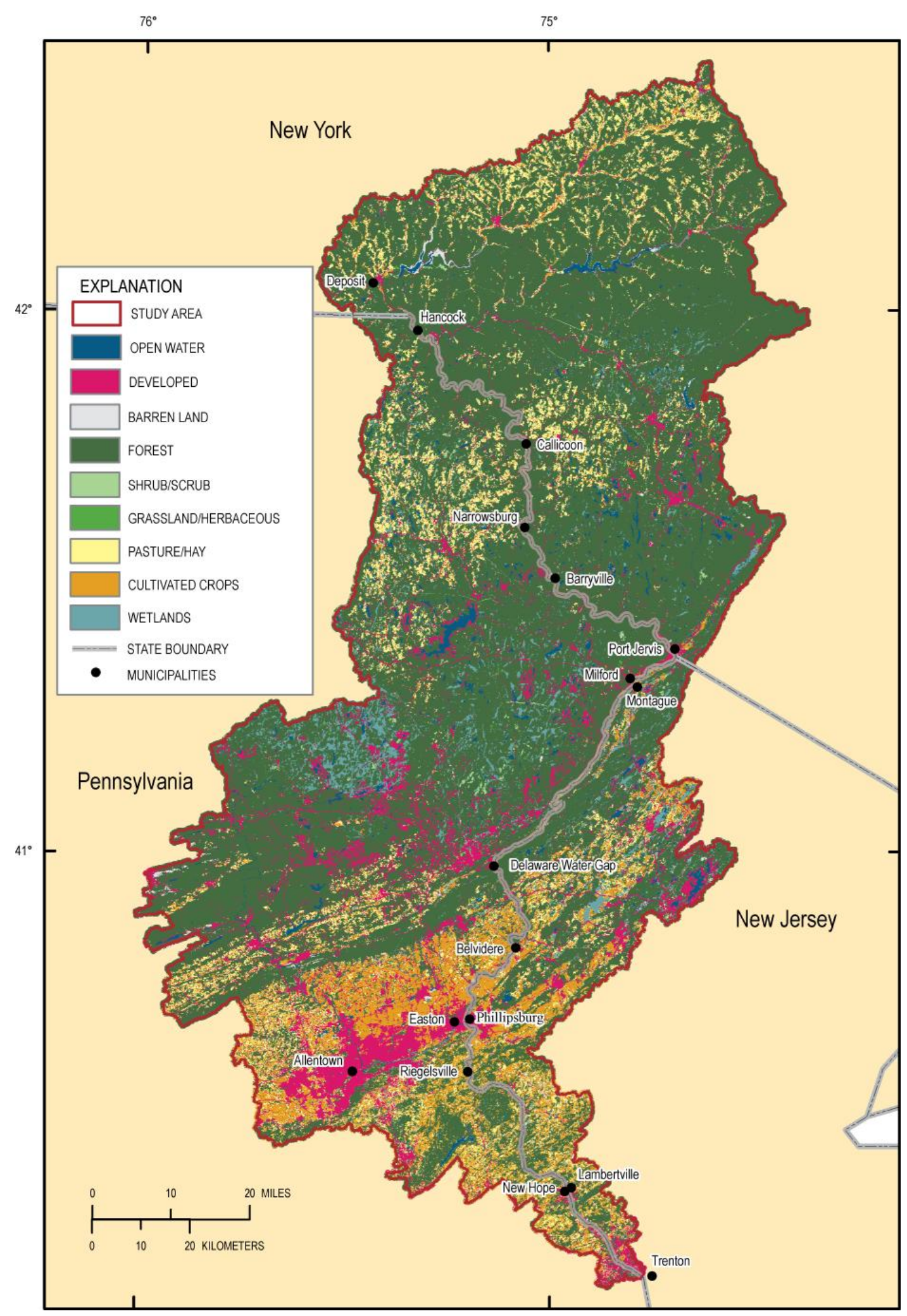

Figure 3. Land-cover data for the Delaware River main-stem subbasin, Pennsylvania, New Jersey, and New York, 2001 (data from Multi-Resolution Land Characteristics Consortium, 2001). 


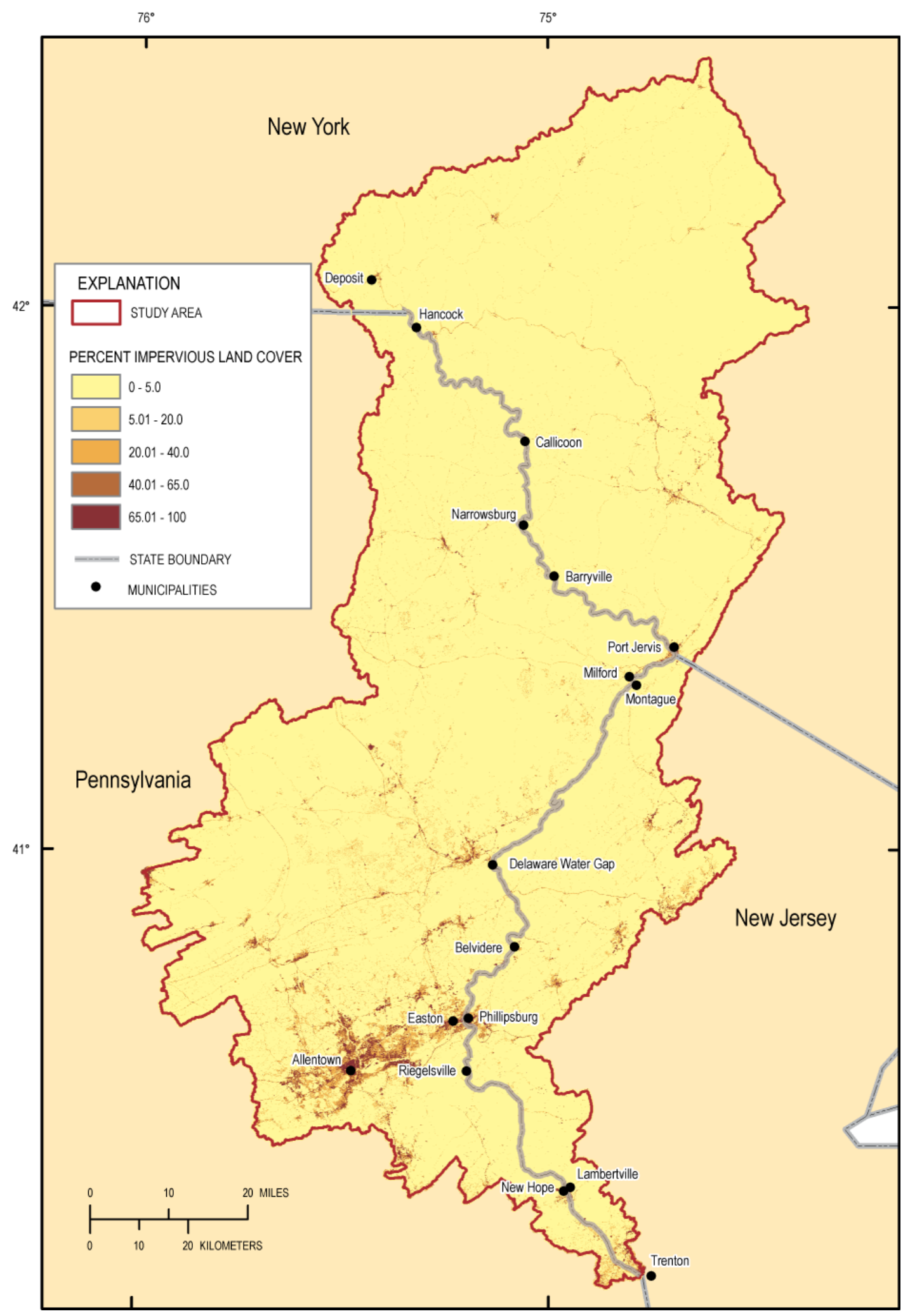

Figure 4. Impervious-surface data for the Delaware River main-stem subbasin, Pennsylvania, New Jersey, and New York, 2001 (data from Multi-Resolution Land Characteristics Consortium, 2001). 


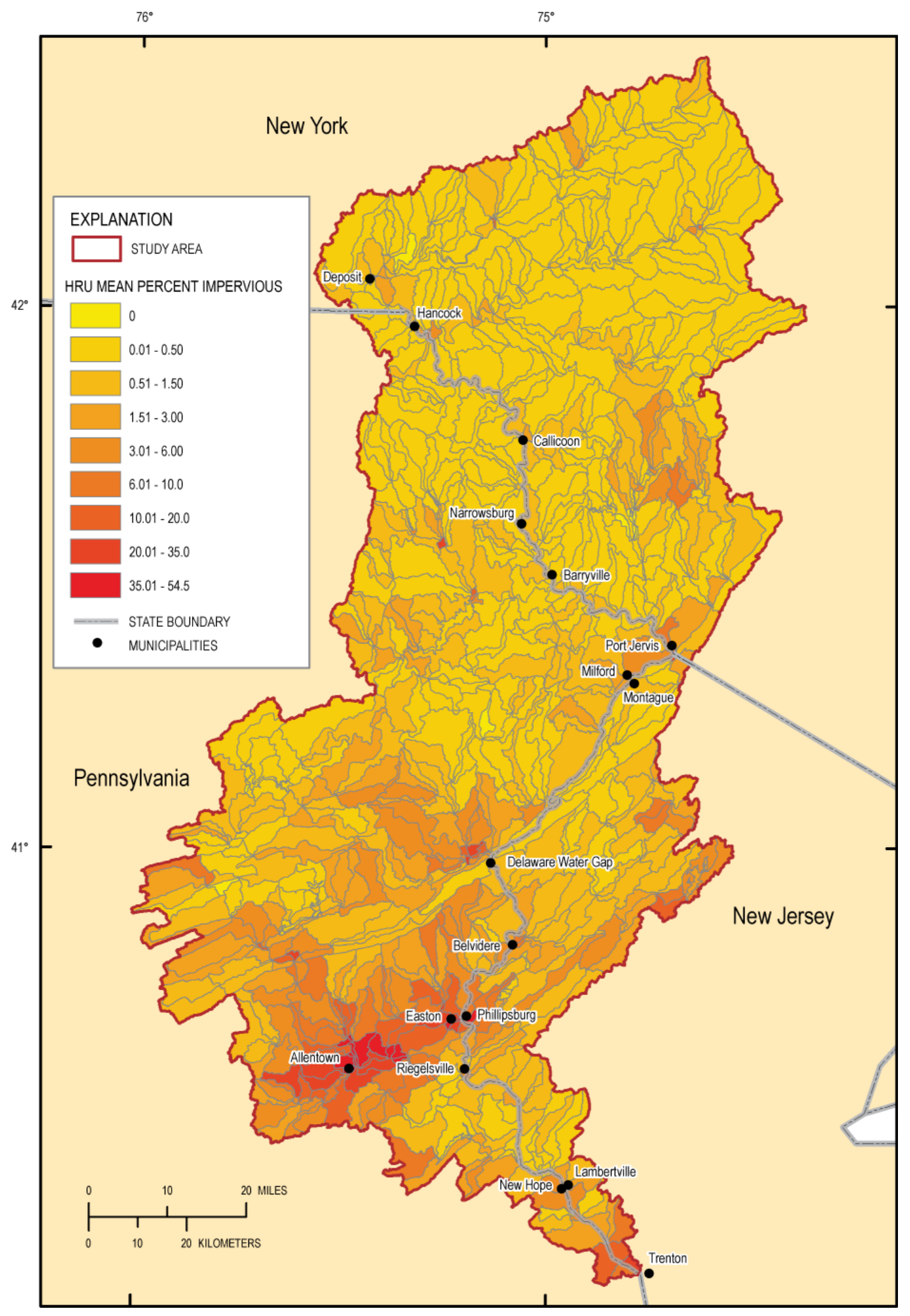

Figure 5. Mean percent impervious values for model hydrologic response units (HRUs) for the Delaware River main-stem subbasin, Pennsylvania, New Jersey, and New York. 


\section{Climate Data}

Climate time-series data - precipitation, air temperature, and solar radiation - are primary input data for PRMS. PRMS operates in two modes, daily and storm, using climate time-series data with time steps of 1 day and 1 hour, respectively. The model operates using a daily time step (daily mode) for periods before and after the storm events and switching to an hourly time step during storm periods (storm mode). Daily-mode data consisted of total daily precipitation, minimum daily air temperature, maximum daily air temperature, and total daily solar radiation. Storm-mode data consisted of total hourly precipitation and total hourly solar radiation. Units of measurement used in the model are inches for precipitation, degrees Fahrenheit for temperature, and Langleys for solar radiation.

\section{Climate Station Data}

Climate data for point stations were obtained from multiple sources. These sources included daily data for 22 NWS Cooperative Climate Station (COOP) network stations, hourly data for 15 stations from the National Climatic Data Center (NCDC), hourly data for 1 station from MARFC records, and daily and hourly data for 7 stations operated by the New York City Department of Environmental Protection (NYCDEP) (fig. 6, table 5). Daily data were retrieved for the period January 1980 through December 2007. Not all data covered the complete period. Hourly data were retrieved for three storm periods: September 13, 2004, through September 27, 2004; March 24, 2005, through April 14, 2005; and June 19, 2006, through July 9, 2006. Because the availability of hourly climate data is limited both in areal coverage and location, not all hourly data were collocated with daily data stations and six daily stations had no corresponding hourly stations. Thirteen hourly stations were at varying distances from their associated daily station.

Daily precipitation and temperature data originated from the COOP network and NYCDEP meteorological stations. The COOP data were retrieved with Downsizer (Ward-Garrison \& others, 2009; U.S. Geological Survey, 2008a), an automated program that performs quality-assurance/qualitycontrol (QA/QC) checks and formats the data suitable for input directly to PRMS. The NYCDEP daily data were limited to at most the period 1994 through 2006. Automated and manual QA/QC were performed by NYCDEP up to the end of calendar year 2005. Data for 2006 did not undergo an agency QA/QC check and should be considered provisional (Glenn Horton, New York City Department of Environmental Protection, written commun., 2007).

Hourly precipitation and temperature data originated from NCDC quality-controlled local climate data (National Climatic Data Center, 2007) and NYCDEP meteorological stations. No additional QA/QC was performed on NCDC hourly data. Additional QA/QC for NYCDEP hourly data consisted of completion of missing time-series entries, parsing for missing or phantom precipitation by comparison to adjacent stations, and visual comparison with radar traces plotted against station locations in a GIS environment using the Java NEXRAD viewer (National Climatic Data Center, 2008). 
Table 5. Selected climate stations in the Delaware River main-stem subbasin, Pennsylvania, New Jersey, and New York.

[COOP, National Weather Service Cooperative Climate Network; DP, Daily precipitation; DT, Daily temperature; NYCDEP, New York City Department of Environmental Protection; HP, Hourly precipitation; HT, Hourly temperature; MARFC, Middle Atlantic River Forecast Center; NCDC, National Climate Data Center]

\begin{tabular}{|c|c|c|c|c|c|}
\hline Station name & State & Source & $\begin{array}{c}\text { Source } \\
\text { designation }\end{array}$ & $\begin{array}{l}\text { Station } \\
\text { altitude } \\
\text { (feet) }\end{array}$ & Type \\
\hline Flemington $5 \mathrm{NNW}$ & N.J. & $\mathrm{COOP}$ & 283029 & 260 & DP, DT \\
\hline Hightstown $2 \mathrm{~W}$ & N.J. & COOP & 283951 & 100 & DP, DT \\
\hline Little Falls & N.J. & COOP & 284887 & 150 & DP, DT \\
\hline Binghamton WSO Airport & N.Y. & $\mathrm{COOP}$ & 300687 & 1,600 & DP, DT \\
\hline Delhi 2 SE & N.Y. & COOP & 302036 & 1,440 & DP, DT \\
\hline Deposit & N.Y. & COOP & 302060 & 1,000 & DP, DT \\
\hline Lansing Manor & N.Y. & COOP & 304575 & 1,100 & DP, DT \\
\hline Walton 2 & N.Y. & COOP & 308932 & 1,480 & DP, DT \\
\hline Allentown AP & $\mathrm{Pa}$. & COOP & 360106 & 390 & DP, DT \\
\hline Blue Marsh Lake & $\mathrm{Pa}$. & COOP & 360785 & 350 & DP, DT \\
\hline Graterford $1 \mathrm{E}$ & $\mathrm{Pa}$. & $\mathrm{COOP}$ & 363437 & 240 & DP, DT \\
\hline Neshaminy Falls & $\mathrm{Pa}$. & COOP & 366194 & 60 & DP, DT \\
\hline Palm 3 SE & $\mathrm{Pa}$. & COOP & 366681 & 300 & DP, DT \\
\hline Pleasant Mount $1 \mathrm{~W}$ & $\mathrm{~Pa}$. & COOP & 367029 & 1,799 & DP, DT \\
\hline Reading 4 NNW & $\mathrm{Pa}$. & COOP & 367322 & 360 & DP, DT \\
\hline Tobyhanna Pocono Mountain A & $\mathrm{Pa}$. & COOP & 368893 & 1,916 & DP, DT \\
\hline Hillriegel Farm on Millbrook near Margaretville & N.Y. & NYCDEP & DPM111 & 2,199 & DP, DT, HP, HT \\
\hline Triple View Farm on Sally's Alley near Vega & N.Y. & NYCDEP & DPM112 & 2,248 & DP, DT, HP, HT \\
\hline Pleasant Mount GOES & $\mathrm{Pa}$. & MARFC & PLXP1 & 1,810 & HP \\
\hline Somerset County Airport & N.J. & $\mathrm{NCDC}$ & SMQ & 100 & HP, HT \\
\hline Trenton-Mercer County Airport & N.J. & $\mathrm{NCDC}$ & TTN & 213 & HP, HT \\
\hline Caldwell-Essex County Airport & N.J. & $\mathrm{NCDC}$ & $\mathrm{CDW}$ & 174 & HP, HT \\
\hline South Jersey Regional Airport & N.J. & $\mathrm{NCDC}$ & VAY & 53 & HP, HT \\
\hline Sussex County Airport & N.J. & $\mathrm{NCDC}$ & FWN & 421 & HP, HT \\
\hline Binghamton Link Field Airport & N.Y. & $\mathrm{NCDC}$ & BGM & 1,637 & HP, HT \\
\hline Monticello-Sullivan County Airport & N.Y. & $\mathrm{NCDC}$ & MSV & 1,403 & HP, HT \\
\hline Montgomery-Orange County Airport & N.J. & $\mathrm{NCDC}$ & MGJ & 365 & HP, HT \\
\hline Allentown-Bethlehem Airport & $\mathrm{Pa}$. & NCDC & $\mathrm{ABE}$ & 384 & HP, HT \\
\hline
\end{tabular}


Table 5. Selected climate stations in the Delaware River main-stem subbasin, Pennsylvania, New Jersey, and New York.—Continued

[COOP, National Weather Service Cooperative Climate Network; DP, Daily precipitation; DT, Daily temperature; NYCDEP, New York City Department of Environmental Protection; HP, Hourly precipitation; HT, Hourly temperature; MARFC, Middle Atlantic River Forecast Center; NCDC, National Climate Data Center]

\begin{tabular}{lcccrl}
\hline \multicolumn{1}{c}{ Station name } & State & Source & $\begin{array}{c}\text { Source } \\
\text { designation }\end{array}$ & $\begin{array}{r}\text { Station } \\
\text { altitude } \\
\text { (feet) }\end{array}$ & Type \\
\hline Pottstown-Limerick Airport & Pa. & NCDC & PTW & 309 & HP, HT \\
Northeast Philadelphia Airport & Pa. & NCDC & PNE & 119 & HP, HT \\
Doylestown Airport & Pa. & NCDC & DYL & 385 & HP, HT \\
Reading-Spatz Field & Pa. & NCDC & RDG & 353 & HP, HT \\
Mount Pocono Airport & Pa. & NCDC & MPO & 1,894 & HP, HT \\
Wilkes Barre Airport & Pa. & NCDC & AVP & 962 & HP, HT \\
\hline
\end{tabular}




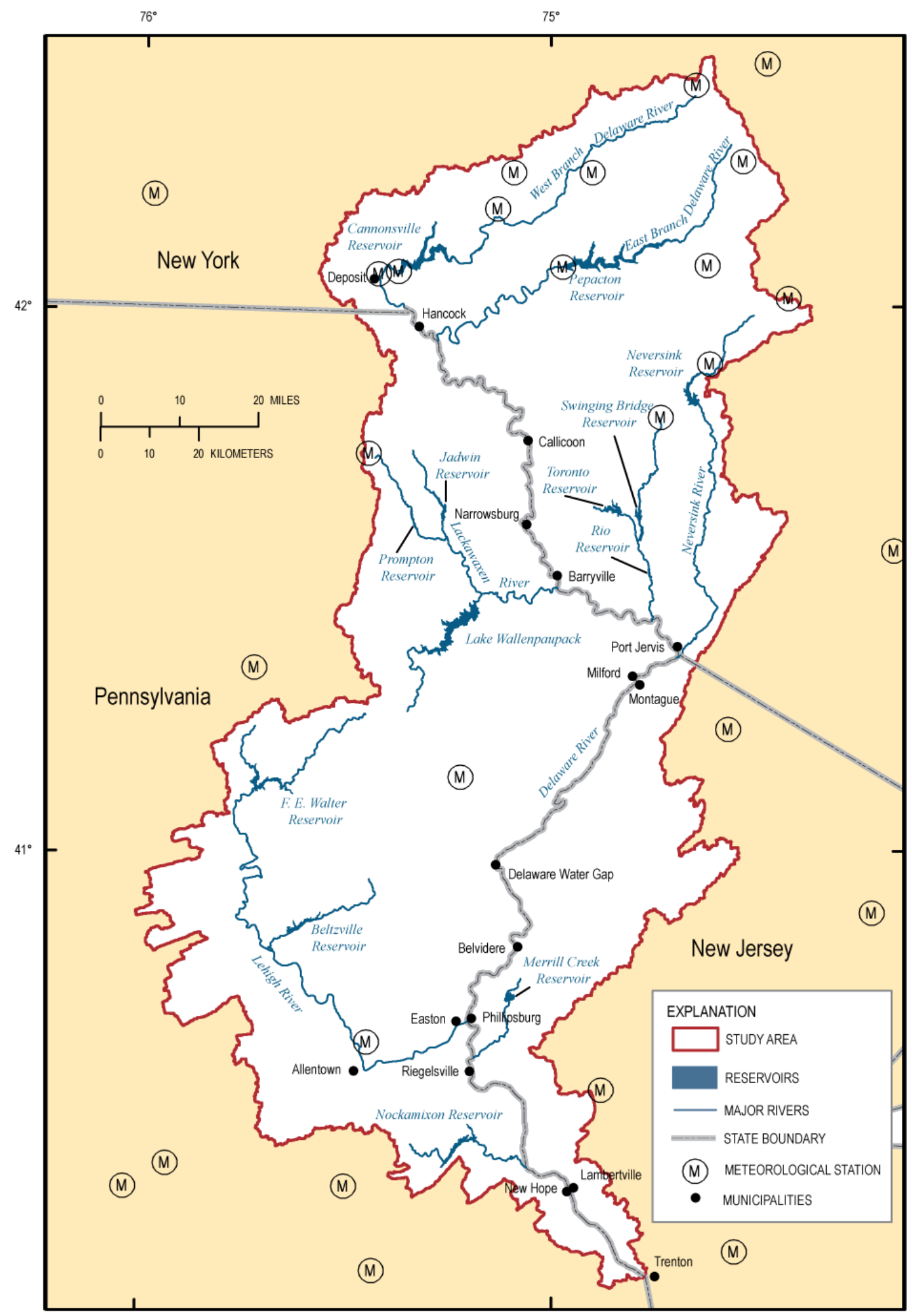

Figure 6. Locations of selected National Oceanic and Atmospheric Administration meteorological stations in the Delaware River main-stem subbasin, Pennsylvania, New Jersey, and New York. 
Table 6. Solar-radiation stations used for model data for the Delaware River main-stem subbasin, Pennsylvania, New Jersey, and New York.

[NSRDB, National Renewable Energy Laboratory National Solar Radiation Database; NRCC, Northeast Regional Climate Center; NYCDEP, New York City Department of Environmental Protection]

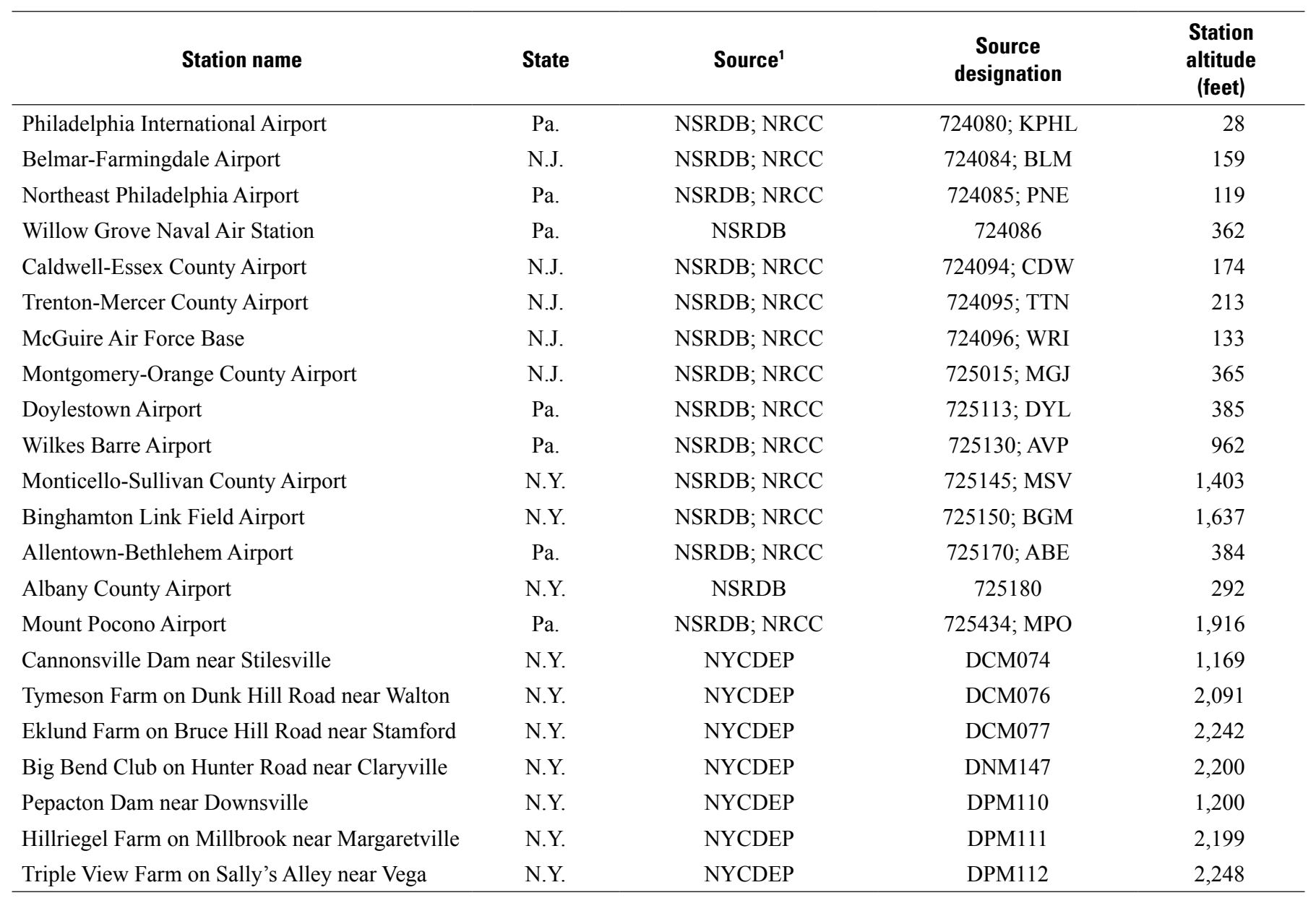

\footnotetext{
${ }^{1}$ Data transitions from NSRDB to NRCC on 1/1/2006.
} 
Solar-radiation data for 15 airports and 7 NYCDEP locations (table 6) were obtained from the National Renewable Energy Laboratory National Solar Radiation Database (NSRDB), the Northeast Regional Climate Center (NRCC), and the NYCDEP. Data for 1980 through 2005 consisted of hourly METSTAT modeled and measured values of global horizontal radiation published by the NSRDB for the airport locations (National Renewable Energy Laboratory, 1992, 2007). Daily solar-radiation data for this period were generated by aggregation of hourly data. For 2006 through 2007, solar-radiation data at 13 airport sites consisted of hourly and daily estimates of total (global) horizontal radiation produced by the NRCC on the basis of a modified Meyers and Dale model (DeGaetano and others, 1993). If data were not available for an hour, available data from a nearby location were substituted. A considerable amount of data was missing for Monticello (MSV). Nearby Stewart Field was the backup station, and its data were used extensively in the Monticello files (Keith Eggleston, Northeast Regional Climate Center, written commun., 2008). No additional QA/QC was performed on NSRDB and NRCC solar-radiation data. The NYCDEP hourly solar-radiation data consisted of measured values collected at seven locations and covered 1994 through 2006. QA/QC for NYCDEP hourly solar-radiation data consisted of parsing for gross radiation errors on the basis of adjacent stations, time of observation errors, duplicate values, and non-zero values during night periods. NYCDEP solar data consisted of hourly data aggregated to total daily.

Review of the temperature and precipitation data quality and initial model-calibration efforts indicated that these hourly station data could not be used in the model-calibration procedures. In particular, available calibration tools for the model were not compatible with different locations for daily and hourly gages. New procedures were developed to estimate the hourly temperature from daily minimum and maximum temperature and to estimate hourly and daily precipitation from NWS hourly radar data.

\section{Estimation of Hourly Temperature Using Daily Station Data}

New procedures were developed to estimate the hourly temperature from daily minimum and maximum temperature. Daily maximum and minimum temperature were produced for each HRU using PRMS in daily mode, and the $x y z$ distribution technique documented by Hay and others (2000), Hay and Clark (2003), and Hay and others (2002). The daily values were used with a modeled hourly temperature variation to produce hourly values of temperature for each HRU.

The method of Erbs and others (1983) was used to estimate the hourly temperature at daily station locations from daily minimum and maximum values. This method was compared against other air-temperature models by Bilbao and others (2002) and shown to perform well and can be adapted to work at daily timescale. For each simulation day in storm mode, the hourly temperature for a HRU, $\mathrm{T}(i h r)$, was computed from the daily maximum temperature (tmax) and minimum temperature (tmin) for the HRU:

$$
\begin{array}{r}
\mathrm{T}(\text { ihr })=\operatorname{tavg}+(\mathrm{A} *(0.4632 * \cos (\mathrm{x}-3.805)+0.0984 * \cos (2 \mathrm{x}-0.360) \\
+0.0168 * \cos (3 \mathrm{x}-0.822)+0.0138 * \cos (4 \mathrm{x}-3.513)))
\end{array}
$$

where $\operatorname{tavg}=(\operatorname{tmax}-\mathrm{tmin}) / 2$

$\mathrm{A}=(\mathrm{tmax}-\mathrm{tmin})$

$\mathrm{x}=(2.0 * 3.14159265) *(i h r-1) / 24$

$i h r=$ index of hour of the day, from 1 to 24 


\section{Precipitation Estimated from Radar Data}

The NWS Multisensor Precipitation Estimate (MPE) data set was used for precipitation input during daily and storm simulations with PRMS and was provided for this study by NOAA's NWS MARFC (Joseph Ostrowski, NWS Middle Atlantic River Forecast Center, written commun., 2008). The MPE is a 4-km resolution gridded data set that is based on NEXRAD radar precipitation measurements. The original NEXRAD values are adjusted by NWS to improve the accuracy and reduce bias using land-based gage measurements. National Weather Service, Hydrology Laboratory (2009) provides background information and technical details on the MPE data sets. The hourly totals MPE data set used for this study covers the Delaware River Basin for 2001-2007. An example of the MPE data for 9 a.m. Eastern Standard Time (EST) on September 18, 2004, is shown in figure 7.

The MPE data sets were preprocessed to reduce computations during PRMS simulations. The MPE was provided as a XMRG formatted data set of hourly totals. This was converted to two text file format data sets for subsequent simulation: (1) a data set of hourly precipitation by HRU, and (2) a data set of daily precipitation by HRU. These text files are much smaller than the original gridded data set, have times converted from GMT to EST, and incorporate mapping of the MPE grid values to the HRUs using a simple area-weighted average. For example, figure 8 shows the model precipitation by HRU for 9 a.m. EST on September 18, 2004. Hourly totals were summed for the daily data set.

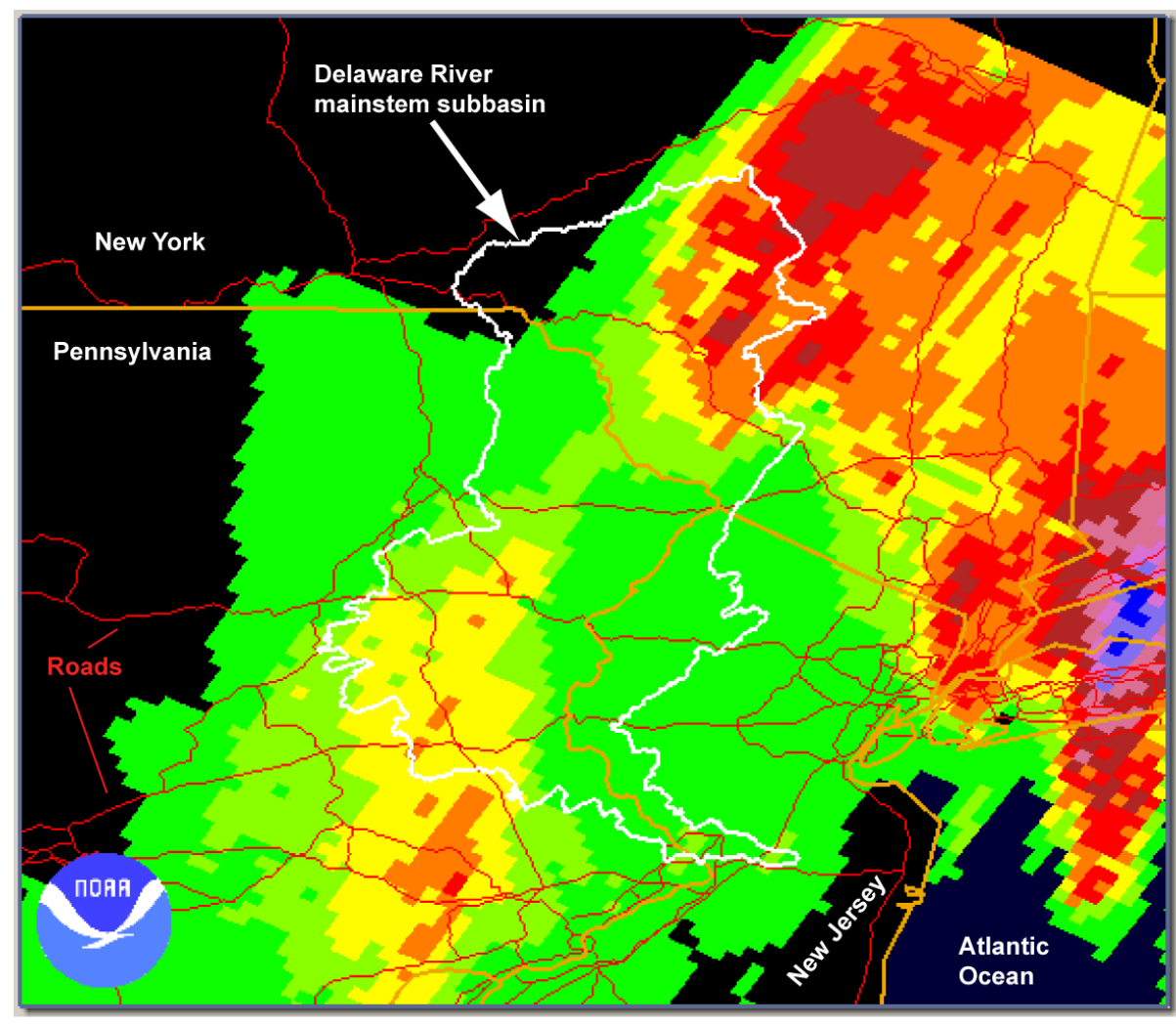

NEXRAD XMRG MPE

MIDDLE ATLANTIC REGION 09/18/2004 14:00:00 GMT

VALID: $2004-09-18$ 14:00:00 SAVED: 2004-09-18 16:13:27 PROCESS FLAG: MPM01 USER ID: paW

Legend: IN (Category)

$>4.00(11)$ $3.00-4.00(10)$ $2.50-3.00(9)$

$2.00-2.50(8)$

\begin{tabular}{l}
$2.00-2.50(8)$ \\
$1.50-2.00(7)$ \\
\hline
\end{tabular} $1.00-1.50(6)$ $0.75-1.00(5)$ $0.50-0.75(4)$ $0.25-0.50(3)$ $0.10-0.25$ $0.01-0.10(1)$ $0.00-0.01(0)$

Precipitation 9:00 am EST in inches

Figure 7. National Weather Service Multi-sensor Precipitation Estimate (MPE) hourly data for 9 a.m. Eastern Standard Time on September 18, 2004, used for model data for the Delaware River main-stem subbasin, Pennsylvania, New Jersey, and New York. 


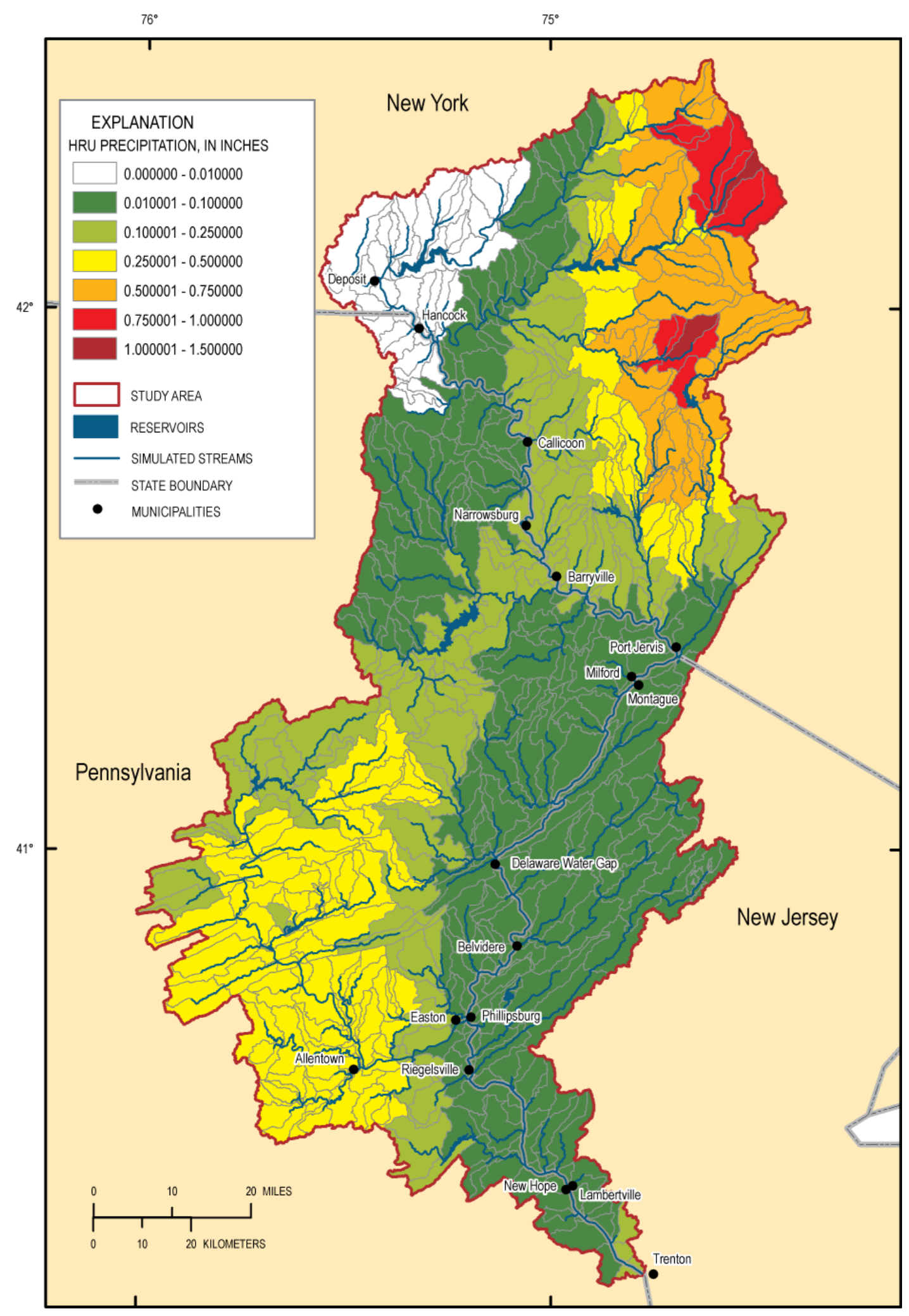

Figure 8. Model hourly precipitation for 9 a.m. Eastern Standard Time on September 18, 2004, for Hydrologic Response Units (HRUs) for the Delaware River main-stem subbasin, Pennsylvania, New Jersey, and New York. 


\section{Model Application}

\section{Calibration and Testing}

Calibration of PRMS included regression and optimization algorithms, as well as manual adjustments. The general goal of the calibration procedure was to minimize the difference between streamflow (discharge) measured at USGS streamgages and the corresponding discharge simulated by PRMS.

The normalized root mean square error (NRMSE) is an objective function that measures the overall difference between the simulated and observed streamflows. For the daily values, $N R M S E_{d}$ is defined as

$$
\operatorname{NRMSE}_{d}=\left(\sum_{n=1}^{\text {ndays }}\left(M S D_{n}-S I M_{n}\right)^{2} / \sum_{n=1}^{\text {ndays }}\left(M S D_{n}-M N\right)^{2}\right)^{1 / 2}
$$

where $n$ is the day index; ndays is the total number of days; and MSD, SIM, and MN are the observed, simulated, and mean observed daily flow. The mean observed daily flow, $M N$, is computed for the days of the simulation period only. If $N R M S E=0$, then the simulated flows are identical to the observed flows. A value of $N R M S E=1$ indicates that the sum of squared differences between the observed and simulated flows is the same as the sum of squared differences between the observed flows and the mean observed flow.

For the hourly values, $N R M S E_{h}$ is defined as

$$
\mathrm{NRMSE}_{h}=\left(\sum_{m=1}^{\text {nhours }}\left(\mathrm{MSH}_{m}-\mathrm{SIMH}_{m}\right)^{2} / \sum_{m=1}^{\text {nhours }}\left(M S H_{m}-M N H\right)^{2}\right)^{1 / 2}
$$

where $m$ is the hour index; nhours is the total number of hours; and $M S H$, SIMH, and $M N H$ are the observed, simulated, and mean observed hourly flow. The mean observed hourly flow, $M N H$, is computed for the hours of the storm-mode simulation only.

Daily and hourly streamflow data from 42 USGS streamgages (table 7 and fig. 9) were acquired for use in model calibration. Simulated streamflow was compared to data from 35 streamgages at corresponding locations, and streamflow data from the other 7 streamgages were used as reservoir discharge for calibration at downstream locations. The streamflow data represent areas draining from 20.2 to $6,780 \mathrm{mi}^{2}$. Streamflow data were collected by the USGS using techniques described by Rantz and others (1982). Continuous streamflow data were retrieved from the National Water Information System (NWIS) (Hoopes, 2004; Sauer, 2002). The hourly calibration simulations included three time periods before, during, and after high-flow events: September 13 to 27, 2004; March 24 to April 14, 2005; and June 19 to July 9, 2006. 
Table 7. Streamgages selected for use in model calibration for the Delaware River main-stem subbasin, Pennsylvania, New Jersey, and New York.

[Use codes: C, calibration; R, reservoir discharge; $N R M S E_{d}$ and $N R M S E_{h}$, normalized root mean square error, daily and hourly respectively]

\begin{tabular}{|c|c|c|c|c|c|}
\hline $\begin{array}{c}\text { U.S. Geological } \\
\text { Survey station } \\
\text { number }\end{array}$ & Station name & $\begin{array}{c}\text { Drainage } \\
\text { area } \\
\text { (square } \\
\text { miles) }\end{array}$ & Use & $\begin{array}{l}\text { Model daily } \\
\text { fit statistic } \\
\text { NRMSE }_{d}\end{array}$ & $\begin{array}{c}\text { Model hourly } \\
\text { fit statistic } \\
\text { NRMSE }_{h}\end{array}$ \\
\hline 01413500 & East Branch Delaware River at Margaretville, N.Y. & 163 & $\mathrm{C}$ & 1.26 & 0.43 \\
\hline 01414000 & Platte Kill at Dunraven, N.Y. & 34.9 & $\mathrm{C}$ & .83 & .45 \\
\hline 01414500 & Mill Brook near Dunraven, N.Y. & 25.2 & $\mathrm{C}$ & .98 & .70 \\
\hline 01415000 & Tremper Kill near Andes, N.Y. & 33.2 & $\mathrm{C}$ & 1.03 & 60 \\
\hline 01417000 & East Branch Delaware River at Downsville, N.Y. & 372 & $\mathrm{R}$ & & \\
\hline 01417500 & East Branch Delaware River at Harvard, N.Y. & 458 & $\mathrm{C}$ & .16 & .32 \\
\hline 01420500 & Beaver Kill at Cooks Falls, N.Y. & 241 & $\mathrm{C}$ & 1.01 & .45 \\
\hline 01421000 & East Branch Delaware River at Fishs Eddy, N.Y.' & 784 & $\mathrm{C}$ & .54 & .25 \\
\hline 01423000 & West Branch Delaware River at Walton, N.Y. & 332 & $\mathrm{C}$ & .60 & .25 \\
\hline 0142400103 & Trout Creek near Trout Creek, N.Y. & 20.2 & $\mathrm{C}$ & .67 & .49 \\
\hline 01425000 & West Branch Delaware River at Stilesville, N.Y. & 456 & $\mathrm{R}$ & & \\
\hline 01426000 & Oquaga Creek at Deposit, N.Y. & 67.6 & $\mathrm{C}$ & .74 & .45 \\
\hline 01426500 & West Branch Delaware River at Hale Eddy, N.Y. & 595 & $\mathrm{C}$ & .19 & .21 \\
\hline 01427510 & Delaware River at Callicoon, N.Y. & 1,820 & $\mathrm{C}$ & .45 & .20 \\
\hline 01428500 & Delaware River above Lackawaxen River near Barryville, N.Y. & 2,020 & $\mathrm{C}$ & .50 & .23 \\
\hline 01428750 & West Branch Lackawaxen River near Aldenville, Pa. & 40.6 & $\mathrm{C}$ & .87 & .46 \\
\hline 01429000 & West Branch Lackawaxen River at Prompton, Pa. & 59.7 & $\mathrm{R}$ & & \\
\hline 01429500 & Dyberry Creek near Honesdale, Pa. & 64.6 & $\mathrm{R}$ & & \\
\hline 01431500 & Lackawaxen River at Hawley, Pa. & 290 & $\mathrm{C}$ & .60 & .37 \\
\hline 01432900 & Mongaup River at Mongaup Valley, N.Y. & 76.6 & $\mathrm{C}$ & .74 & .28 \\
\hline 01434000 & Delaware River at Port Jervis, N.Y. & 3,070 & $\mathrm{C}$ & .64 & .22 \\
\hline 01435000 & Neversink River near Claryville, N.Y. & 66.6 & $\mathrm{C}$ & 1.39 & .57 \\
\hline 01436000 & Neversink River at Neversink, N.Y. & 92.6 & $\mathrm{R}$ & & \\
\hline 01436690 & Neversink River at Bridgeville, N.Y. & 171 & $\mathrm{C}$ & .52 & .42 \\
\hline 01437500 & Neversink River at Godeffroy, N.Y. & 307 & $\mathrm{C}$ & .59 & .39 \\
\hline 01438500 & Delaware River at Montague, N.J. & 3,480 & $\mathrm{C}$ & .64 & .23 \\
\hline 01439500 & Bush Kill at Shoemakers, Pa. & 117 & $\mathrm{C}$ & .78 & .36 \\
\hline 01440000 & Flat Brook near Flatbrookville, N.J. & 64 & $\mathrm{C}$ & .55 & .42 \\
\hline 01442500 & Brodhead Creek at Minisink Hills, Pa. & 259 & $\mathrm{C}$ & .83 & .35 \\
\hline 01443500 & Paulins Kill at Blairstown, N.J. & 126 & $\mathrm{C}$ & .72 & .45 \\
\hline 01446500 & Delaware River at Belvidere, N.J. & 4,535 & $\mathrm{C}$ & .72 & .21 \\
\hline 01447500 & Lehigh River at Stoddartsville, Pa. & 91.7 & $\mathrm{C}$ & .67 & .33 \\
\hline 01447720 & Tobyhanna Creek near Blakeslee, Pa. & 118 & $\mathrm{C}$ & .56 & .26 \\
\hline 01447800 & Lehigh River below Francis E Walter Res near White Haven, Pa. & 290 & $\mathrm{R}$ & & \\
\hline 01449000 & Lehigh River at Lehighton, Pa. & 591 & $\mathrm{C}$ & .34 & .48 \\
\hline 01449360 & Pohopoco Creek at Kresgeville, Pa. & 49.9 & $\mathrm{C}$ & .50 & .26 \\
\hline 01449800 & Pohopoco Creek below Beltzville Dam near Parryville, Pa. & 96.4 & $\mathrm{R}$ & & \\
\hline 01450500 & Aquashicola Creek at Palmerton, Pa. & 76.7 & $\mathrm{C}$ & .86 & .45 \\
\hline 01451000 & Lehigh River at Walnutport, Pa. & 889 & $\mathrm{C}$ & .40 & .34 \\
\hline 01452000 & Jordan Creek at Allentown, Pa. & 75.8 & $\mathrm{C}$ & .54 & .47 \\
\hline 01453000 & Lehigh River at Bethlehem, Pa. & 1,279 & $\mathrm{C}$ & 0.49 & .27 \\
\hline 01463500 & Delaware River at Trenton, N.J. & 6,780 & $\mathrm{C}$ & 0.79 & .27 \\
\hline
\end{tabular}

${ }^{1}$ Includes record from discontinued gage 01420980. 


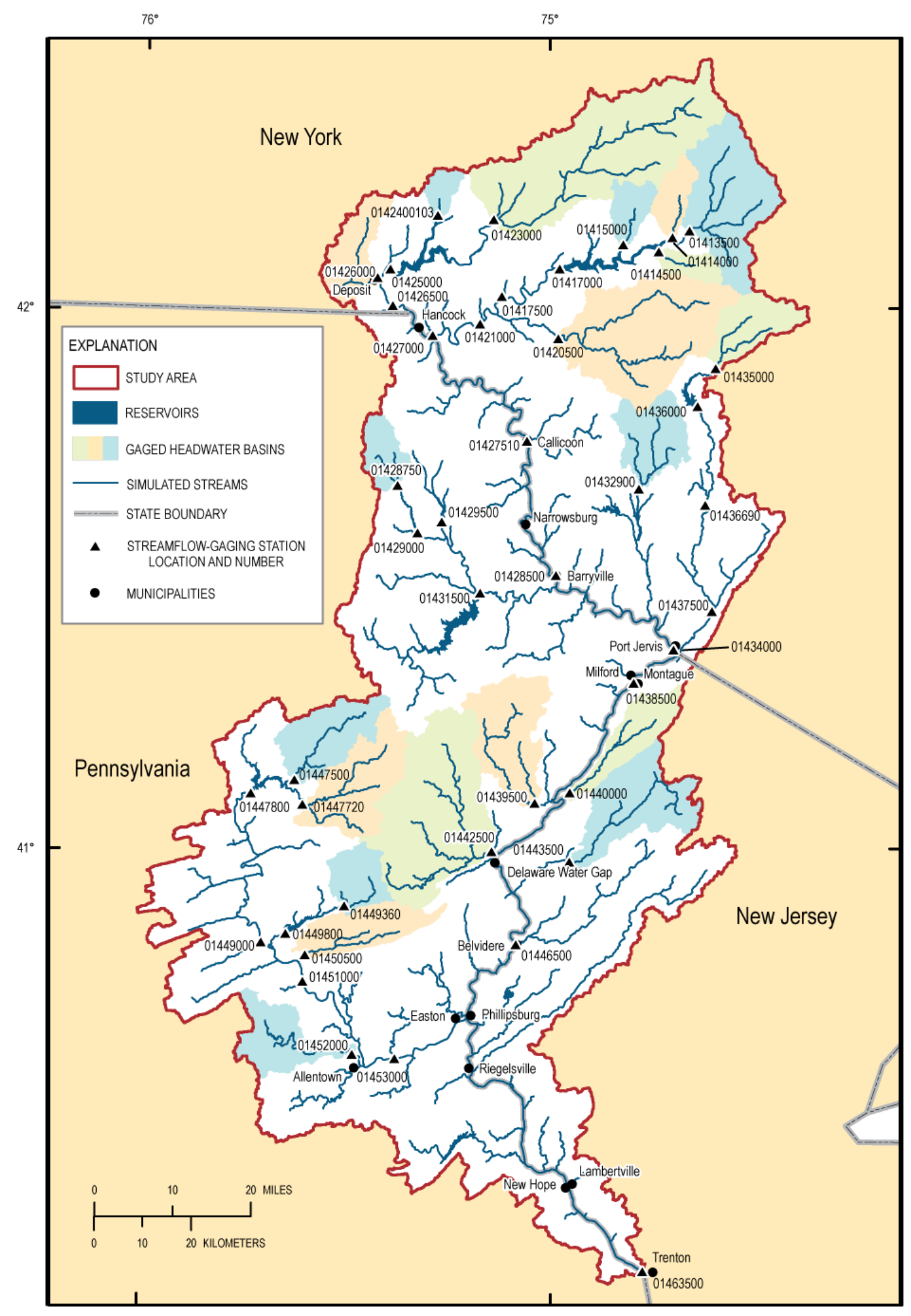

Figure 9. Location of selected streamgages in the Delaware River main-stem subbasin, Pennsylvania, New Jersey, and New York. (Streamgages are listed in table 7.) 
Automatic calibration methods were used for the PRMS model, first in daily mode, and then in storm mode. The automatic calibration is performed using LUCA (Hay and Umemoto, 2007; Hay and others, 2006), an automatic calibration tool that adjusts model parameters to reduce the difference between simulated and measured daily streamflow. LUCA is based on the Shuffled Complex Evolution (Duan and others, 1993) global search algorithm that assures that intermediate and final states of the model are simulated consistently with measured values (Hay and Umemoto, 2007). Subbasins of the model were delineated above USGS streamgages, and the parameters of HRUs above each station are adjusted separately during LUCA calibration.

Headwater subbasins of the model were calibrated first (fig. 9). Calibration of model parameters for subbasins below the headwaters could then be calibrated, using the headwater flows from those calibrated subbasins. Thus, the calibration procedure started in the headwaters and then moved down through the watershed. Parameters for ungaged subbasins were assigned using values from the closest gaged subbasin.

Because the PRMS model is designed to provide runoff and inflows for a HEC-ResSim floodanalysis reservoir-simulation model, the reservoirs simulated in that model are not explicitly included in the PRMS model. This required a modified procedure for calibration of PRMS local inflows downstream of the reservoirs. For daily calibration of these downstream subbasins, the measured daily outflow from the reservoir was used as an inflow to the subbasin. In this way, the measured streamflow further downstream could be used as a calibration target for local flows below the reservoir in the PRMS model. Calibration changed the parameters controlling local inflows downstream of the reservoir, but the discharge from the reservoir was not adjusted. For the hourly calibration, additional manual calibration was conducted by using the HEC-ResSim model to simulate flow through the reservoirs, and to compute streamflow downstream of the reservoirs. Thus, the daily calibration uses only PRMS results and observed reservoir outflows, while hourly calibration results use both PRMS and HEC-ResSim for simulation of flows at streamgage locations below the reservoirs. Streamflow at headwater streamgages, which is not regulated by the reservoirs, is fully simulated by PRMS alone, for both daily and hourly simulations.

The PRMS model was calibrated in a three-step process: automatic calibration in daily mode, automatic calibration in storm mode, and manual calibration of storm volumes for main-stem gage locations. The first step was calibration of the parameters shown in table 8 using the model in daily mode. Two objective functions were used for the daily mode calibration, the absolute difference between the observed and simulated total volume of discharge, and the $N R M S E_{d}$ of the daily flows. The first objective function was used to determine precipitation adjustment factors, separately for rain and snow, by month, so that the total volume of water applied to the basin as precipitation is consistent with the total discharge measured at the subbasin streamgage.

The second objective function for the daily-mode calibration is a measure of the overall match between the simulated and observed daily hydrograph. Parameters adjusted on the basis of this measure of model fit are generally related to the partitioning of water between relatively slow and fast subsurface runoff reservoirs. The groundwater reservoir has a more delayed release of water than the soil-moisture reservoir. Daily calibration is chosen for these parameters because the timescale of release from both subsurface reservoirs is on the order of days, not hours. A single adjustment of each parameter was used for the HRUs within each subbasin.

The second step of the automatic calibration using LUCA was storm-mode (hourly) calibration of the parameters listed in table 9. This method was useful in improving the simulation in headwater basins. Parameters for ungaged basins in the model were set at values calibrated from the nearest subbasin. 
Table 8. Parameters calibrated in each step of the calibration process, with the model in daily mode.

[Dimensions: $\quad$ nmths, number of months $=12$; nsub, number of subbasins $=145$; nhru, number of hydrologic response units (HRUs) $=869$; PRMS, Precipitation Runoff Modeling System]

\begin{tabular}{|c|c|c|c|c|c|c|}
\hline $\begin{array}{l}\text { Calibration } \\
\text { data set }\end{array}$ & $\begin{array}{l}\text { Objective } \\
\text { function }\end{array}$ & $\begin{array}{l}\text { PRMS parameters } \\
\text { used to calibrate } \\
\text { model state }\end{array}$ & Dimensions & Range & $\begin{array}{l}\text { Parameter } \\
\text { description }\end{array}$ & Comments \\
\hline $\begin{array}{l}\text { Volume of storm } \\
\text { period }\end{array}$ & $\begin{array}{l}\text { Absolute Differ- } \\
\text { ence }\end{array}$ & rain_sub_adj & nmths $x$ nsub & $0-3$ & $\begin{array}{l}\text { Adjustment factor } \\
\text { for precipita- } \\
\text { tion on rain } \\
\text { days }\end{array}$ & $\begin{array}{l}\text { Calibrate as a } \\
\text { mean value. } \\
\text { Combine } \\
\text { calibrated }\end{array}$ \\
\hline \multirow{4}{*}{$\begin{array}{l}\text { Daily Values } \\
\text { during storm } \\
\text { periods }\end{array}$} & & smidx_coef & nhru & $0.0001-1$ & $\begin{array}{l}\text { Coefficient in } \\
\text { non-linear } \\
\text { surface runoff } \\
\text { contributing } \\
\text { area algorithm }\end{array}$ & $\begin{array}{l}\text { rameter value. } \\
\text { Interpolate to } \\
\text { uncalibrated } \\
\text { subbasins } \\
\text { HRUs }\end{array}$ \\
\hline & & smidx_exp & nhru & $0.2-0.8$ & $\begin{array}{l}\text { Exponent in on- } \\
\text { linear surface } \\
\text { runoff con- } \\
\text { tribution area } \\
\text { algorithm }\end{array}$ & \\
\hline & & soil_rechr_max & nhru & $0-20$ & $\begin{array}{l}\text { Maximum avail- } \\
\text { able water } \\
\text { holding capac- } \\
\text { ity for soil } \\
\text { recharge zone }\end{array}$ & \\
\hline & & soil2gw_max & nhru & $0.0001-0.5$ & $\begin{array}{l}\text { Maximum rate } \\
\text { of soil water } \\
\text { excess moving } \\
\text { to groundwater }\end{array}$ & \\
\hline
\end{tabular}


Table 9. Parameters calibrated in each step of the calibration process, with the model in storm mode.

\begin{tabular}{|c|c|c|c|c|c|c|}
\hline $\begin{array}{l}\text { Calibration } \\
\text { data set }\end{array}$ & $\begin{array}{l}\text { Objective } \\
\text { function }\end{array}$ & $\begin{array}{l}\text { PRMS parameters } \\
\text { used to calibrate } \\
\text { model state }\end{array}$ & Dimensions & Range & $\begin{array}{l}\text { Parameter } \\
\text { description }\end{array}$ & Comments \\
\hline \multirow[t]{4}{*}{$\begin{array}{l}\text { Values during } \\
\text { storm periods }\end{array}$} & \multirow[t]{4}{*}{$N R M S E_{h}$} & kpar & nhru & $0-5$ & $\begin{array}{l}\text { Hydraulic conductiv- } \\
\text { ity of the transmis- } \\
\text { sion zone }\end{array}$ & \multirow{4}{*}{$\begin{array}{l}\text { Calibrate as a } \\
\text { mean value. } \\
\text { Combine cali- } \\
\text { brated values } \\
\text { from each } \\
\text { subbasin into a } \\
\text { final parameter } \\
\text { value. }\end{array}$} \\
\hline & & psp & nhru & $0.1-25$ & $\begin{array}{l}\text { Moisture deficit times } \\
\text { capillary drive }\end{array}$ & \\
\hline & & mf_min & nhru & $0.1-4$ & Minimum melt factor & \\
\hline & & wind_adjust & nhru & $0.02-1$ & $\begin{array}{l}\text { Rate of melt due to } \\
\text { wind effects }\end{array}$ & \\
\hline
\end{tabular}


An iterative manual calibration procedure was also used for downstream subbasins and ungaged subbasins. Simulated local inflows computed by PRMS were used with the HEC-ResSim reservoir simulation and flow-routing model component to compute main-stem flows at streamgage locations. On the basis of the comparison between simulated and observed flows at a streamgage, the precipitation adjustment factors for the subbasin providing local inflow above the streamgage were calibrated. Subbasin precipitation adjustment factors were calibrated in this manner proceeding downstream in the basin. This method improved the match between simulated and observed flow volumes but did not substantially affect the shape of simulated hydrographs.

The PRMS model was judged to be adequately calibrated for the generation of reservoir inflows, local inflows and unregulated tributary flows for input into the HEC-ResSim model to assess the effects of watershed characteristics on flooding in regulated tributaries and the main-stem Delaware River. The $N R M S E_{h}$ measure of model fit for hourly simulation periods is generally lower than the $N R M S E_{d}$ measure for daily simulation periods, indicating that the model is generally more accurate for the hourly simulation periods (table 7). This reflects the focus of the sequential model calibration effort on the hourly simulation of the time periods before, during, and after the three high-flow events. The simulated streamflow is generally more accurate for larger rivers and locations downstream of reservoirs, and less accurate for headwater or unregulated streams. This reflects the design of the model, by HRU and stream discretization, to provide a tool for managing streamflow in the large rivers in the study area, and to evaluate the effects of operations of the reservoirs. The observed and simulated mean and standard deviations of hourly streamflow further illustrate the model performance (table 10). In general, the simulated mean flows are larger than the observed mean flow, which may reflect the effect of manual adjustments to precipitation MPE data. These manual adjustments were made to visually improve the overall match between the simulated and observed storm volumes and may reflect a bias towards matching the high flows.

Simulated and observed hydrographs at streamgage locations also demonstrate the model's ability to reproduce streamflows that were observed during the flood event (figs. 10-15). Simulated hydrographs are smoother than observed hydrographs, suggesting that the model, using a 1-hour time step, does not capture all the temporal variability during the watershed hydrologic processes controlling streamflow. During calibration procedures, backwater effects on the stage at the Minisink Hills streamgage were identified, and the corresponding discharge data were removed from the observed record (fig. 10, for example). Overall, the visual match between observed and simulated hydrographs is better at streamgages on main rivers below reservoirs than at headwater and unregulated locations. These results are consistent with the model fit statistics.

The input data files for the calibrated PRMS model are available online at http://pa.water.usgs.gov/drbfam. This website also provides links to the software used in the model, the documentation, and other information related to the Flood-Analysis Model. 
Table 10. Observed and simulated mean and standard deviation of hourly streamflow, in cubic feet per second, for streamgages used for model calibration for the Delaware River main-stem subbasin, Pennsylvania, New Jersey, and New York.

[Calibration periods: September 2004: September 13, 1:00 am to September 28, 12:00 am; April 2005: March 24, 1:00 am to April 15, 12:00 am; June 2006: June $19,1: 00$ am to July $10,12: 00 \mathrm{am}]$

\begin{tabular}{|c|c|c|c|c|c|c|c|}
\hline \multirow{3}{*}{$\begin{array}{c}\text { U.S. Geological } \\
\text { Survey station } \\
\text { number }\end{array}$} & \multirow{3}{*}{ Station name } & \multicolumn{6}{|c|}{ Mean hourly streamflow (cubic feet per second) } \\
\hline & & \multicolumn{2}{|c|}{ September 2004} & \multicolumn{2}{|c|}{ April 2005} & \multicolumn{2}{|c|}{ June 2006} \\
\hline & & Observed & Simulated & Observed & Simulated & Observed & Simulated \\
\hline 01413500 & $\begin{array}{l}\text { East Branch Delaware River at Margaretville, } \\
\text { N.Y. }\end{array}$ & 1,050 & 1,720 & 1,540 & 1,900 & 1,250 & 1,790 \\
\hline 01414000 & Platte Kill at Dunraven, N.Y. & 240 & 350 & 370 & 450 & 220 & 270 \\
\hline 01414500 & Mill Brook near Dunraven, N.Y. & 140 & 250 & 210 & 260 & 120 & 200 \\
\hline 01415000 & Tremper Kill near Andes, N.Y. & 190 & 290 & 270 & 360 & 200 & 300 \\
\hline 01417500 & East Branch Delaware River at Harvard, N.Y. & 2,960 & 3,730 & 3,180 & 3,500 & 3,580 & 4,690 \\
\hline 01420500 & Beaver Kill at Cooks Falls, N.Y. & 2,540 & 3,130 & 3,420 & 3,500 & 2,460 & 3,230 \\
\hline 01421000 & East Branch Delaware River at Fishs Eddy, N.Y. ${ }^{1}$ & 6,340 & 7,830 & 5,810 & 6,230 & 7,750 & 9,120 \\
\hline 01423000 & West Branch Delaware River at Walton, N.Y. & 2,040 & 2,290 & 2,920 & 3,140 & 2,920 & 3,040 \\
\hline 0142400103 & Trout Creek near Trout Creek, N.Y. & 180 & 250 & 170 & 220 & 210 & 280 \\
\hline 01426000 & Oquaga Creek at Deposit, N.Y. & 510 & 750 & 910 & 860 & 780 & 1,000 \\
\hline 01426500 & West Branch Delaware River at Hale Eddy, N.Y. & 3,960 & 4,530 & 5,260 & 5,710 & 5,550 & 6,310 \\
\hline 01427510 & Delaware River at Callicoon, N.Y. & 14,200 & 17,310 & 18,390 & 19,210 & 19,170 & 21,490 \\
\hline 01428500 & $\begin{array}{l}\text { Delaware River above Lackawaxen River near } \\
\text { Barryville, N.Y. }\end{array}$ & 16,080 & 19,030 & 20,520 & 21,330 & 13,690 & 17,140 \\
\hline 01428750 & $\begin{array}{l}\text { West Branch Lackawaxen River near Aldenville, } \\
\text { Pa. }\end{array}$ & 260 & 310 & 620 & 580 & 900 & 800 \\
\hline 01431500 & Lackawaxen River at Hawley, Pa. & 2,270 & 2,680 & 3,840 & 4,210 & 4,130 & 4,800 \\
\hline 01432900 & Mongaup River at Mongaup Valley, N.Y. & 540 & 650 & 830 & 890 & 430 & 460 \\
\hline 01434000 & Delaware River at Port Jervis, N.Y. & 22,950 & 27,030 & 30,520 & 31,650 & 27,390 & 32,400 \\
\hline 01435000 & Neversink River near Claryville, N.Y. & 470 & 760 & 870 & 910 & 620 & 800 \\
\hline 01436690 & Neversink River at Bridgeville, N.Y. & 820 & 1,050 & 2,040 & 2,390 & 1,120 & 1,690 \\
\hline 01437500 & Neversink River at Godeffroy, N.Y. & 1,360 & 1,790 & 3,490 & 3,710 & 1,120 & 1,900 \\
\hline 01438500 & Delaware River at Montague, N.J. & 26,220 & 30,080 & 35,690 & 37,260 & 30,010 & 35,120 \\
\hline 01439500 & Bush Kill at Shoemakers, Pa. & 1,040 & 1,010 & 1,200 & 1,100 & 870 & 800 \\
\hline 01440000 & Flat Brook near Flatbrookville, N.J. & 350 & 440 & 500 & 490 & 530 & 360 \\
\hline 01442500 & Brodhead Creek at Minisink Hills, Pa. & 1,840 & 2,010 & 2,520 & 2,450 & 2,260 & 2,260 \\
\hline 01443500 & Paulins Kill at Blairstown, N.J. & 660 & 740 & 930 & 920 & 490 & 480 \\
\hline 01446500 & Delaware River at Belvidere, N.J. & 34,410 & 39,090 & 48,420 & 47,920 & 37,540 & 42,610 \\
\hline 01447500 & Lehigh River at Stoddartsville, Pa. & 880 & 1,010 & 920 & 960 & 950 & 1,070 \\
\hline 01447720 & Tobyhanna Creek near Blakeslee, Pa. & 1,240 & 1,410 & 1,370 & 1,320 & 1,340 & 1,350 \\
\hline 01449000 & Lehigh River at Lehighton, $\mathrm{Pa}$. & 4,400 & 5,890 & 5,990 & 5,630 & 5,910 & 6,500 \\
\hline 01449360 & Pohopoco Creek at Kresgeville, Pa. & 360 & 360 & 440 & 410 & 340 & 310 \\
\hline 01450500 & Aquashicola Creek at Palmerton, $\mathrm{Pa}$. & 730 & 960 & 680 & 760 & 540 & 710 \\
\hline 01451000 & Lehigh River at Walnutport, Pa. & 6,980 & 8,570 & 8,880 & 8,390 & 8,840 & 9,530 \\
\hline 01452000 & Jordan Creek at Allentown, $\mathrm{Pa}$. & 550 & 700 & 710 & 810 & 410 & 500 \\
\hline 01453000 & Lehigh River at Bethlehem, Pa. & 8,680 & 10,750 & 11,690 & 10,720 & 10,470 & 11,090 \\
\hline 01463500 & Delaware River at Trenton, N.J. & 45,990 & 58,000 & 62,560 & 66,800 & 49,910 & 61,600 \\
\hline
\end{tabular}

\footnotetext{
${ }^{1}$ Includes record from discontinued gage 01420980.
} 
Table 10. Observed and simulated mean and standard deviation of hourly streamflow, in cubic feet per second, for streamflow-gaging stations used for model calibration for the Delaware River main-stem subbasin, Pennsylvania, New Jersey, and New York.-Continued

[Calibration periods: September 2004: September 13, 1:00 am to September 28, 12:00 am; April 2005: March 24, 1:00 am to April 15, 12:00 am; June 2006: June $19,1: 00$ am to July $10,12: 00 \mathrm{am}]$

\begin{tabular}{|c|c|c|c|c|c|c|}
\hline \multirow{3}{*}{$\begin{array}{c}\text { U.S. Geological } \\
\text { Survey station } \\
\text { number }\end{array}$} & \multicolumn{6}{|c|}{ Standard deviation of hourly streamflow (cubic feet per second) } \\
\hline & \multicolumn{2}{|c|}{ September 2004} & \multicolumn{2}{|c|}{ April 2005} & \multicolumn{2}{|c|}{ June 2006} \\
\hline & Observed & Simulated & Observed & Simulated & Observed & Simulated \\
\hline 01413500 & 2,040 & 2,300 & 2,050 & 2,250 & 1,800 & 2,020 \\
\hline 01414000 & 470 & 510 & 450 & 480 & 350 & 400 \\
\hline 01414500 & 400 & 350 & 300 & 320 & 180 & 210 \\
\hline 01415000 & 470 & 430 & 340 & 410 & 370 & 500 \\
\hline 01417500 & 4,620 & 4,370 & 4,420 & 4,290 & 5,360 & 6,040 \\
\hline 01420500 & 6,460 & 5,130 & 6,490 & 4,950 & 6,200 & 5,320 \\
\hline 01421000 & 10,680 & 10,170 & 8,260 & 8,300 & 13,870 & 12,880 \\
\hline 01423000 & 3,390 & 3,200 & 3,400 & 3,530 & 5,530 & 5,300 \\
\hline 0142400103 & 390 & 410 & 250 & 270 & 480 & 540 \\
\hline 01426000 & 1,240 & 1,160 & 930 & 980 & 2,240 & 1,880 \\
\hline 01426500 & 4,150 & 4,550 & 5,140 & 5,220 & 8,860 & 9,820 \\
\hline 01427510 & 22,260 & 20,750 & 21,520 & 21,450 & 31,740 & 31,570 \\
\hline 01428500 & 24,680 & 22,750 & 23,740 & 23,420 & 21,570 & 23,340 \\
\hline 01428750 & 520 & 430 & 1,260 & 890 & 1,740 & 1,490 \\
\hline 01431500 & 3,710 & 3,350 & 4,180 & 4,010 & 6,400 & 6,230 \\
\hline 01432900 & 940 & 960 & 1,140 & 1,220 & 680 & 710 \\
\hline 01434000 & 32,570 & 29,960 & 33,030 & 31,360 & 41,790 & 43,120 \\
\hline 01435000 & 880 & 980 & 1,780 & 1,130 & 1,220 & 970 \\
\hline 01436690 & 1,400 & 1,220 & 3,730 & 3,240 & 2,000 & 1,690 \\
\hline 01437500 & 1,530 & 1,530 & 4,920 & 4,560 & 2,000 & 2,070 \\
\hline 01438500 & 37,170 & 32,170 & 41,180 & 37,570 & 47,010 & 45,790 \\
\hline 01439500 & 1,210 & 1,240 & 1,140 & 1,330 & 1,050 & 1,250 \\
\hline 01440000 & 660 & 560 & 530 & 520 & 400 & 420 \\
\hline 01442500 & 2,740 & 3,190 & 3,270 & 3,820 & 4,730 & 4,440 \\
\hline 01443500 & 880 & 910 & 750 & 990 & 480 & 450 \\
\hline 01446500 & 43,770 & 37,070 & 50,170 & 44,880 & 54,120 & 53,900 \\
\hline 01447500 & 1,750 & 1,780 & 1,150 & 1,290 & 1,850 & 2,080 \\
\hline 01447720 & 2,190 & 2,170 & 1,990 & 1,970 & 2,490 & 2,080 \\
\hline 01449000 & 3,690 & 4,540 & 3,360 & 3,700 & 5,720 & 5,600 \\
\hline 01449360 & 420 & 450 & 390 & 470 & 400 & 450 \\
\hline 01450500 & 1,270 & 1,350 & 750 & 830 & 760 & 740 \\
\hline 01451000 & 6,610 & 6,920 & 5,500 & 5,380 & 8,980 & 8,590 \\
\hline 01452000 & 1,230 & 1,210 & 1,020 & 880 & 670 & 720 \\
\hline 01453000 & 9,700 & 9,540 & 7,610 & 7,420 & 10,450 & 10,510 \\
\hline 01463500 & 51,090 & 49,250 & 54,650 & 53,980 & 61,820 & 66,780 \\
\hline
\end{tabular}




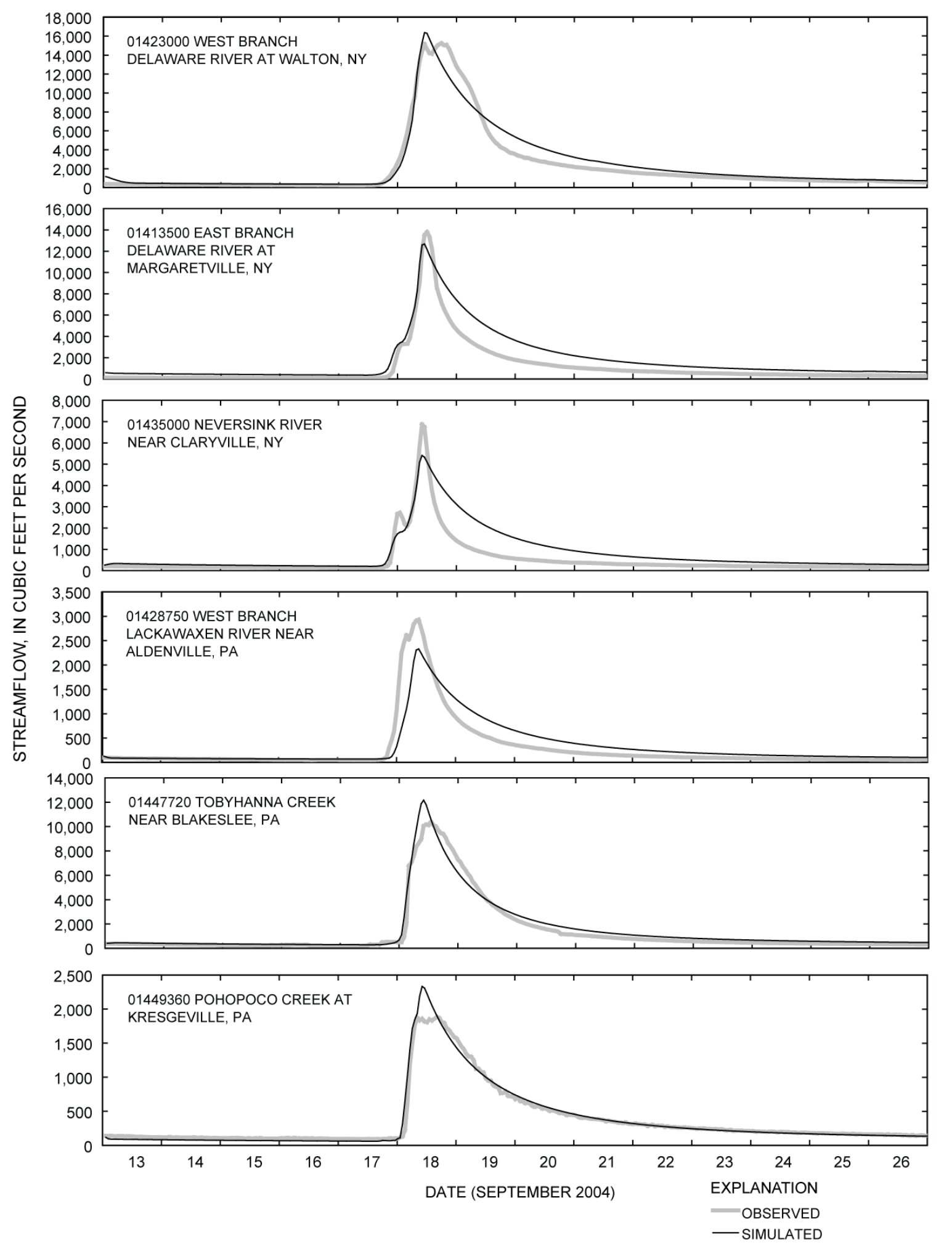

Figure 10. Simulated and observed streamflow, September 13 to 26, 2004, at selected U.S. Geological Survey streamgages in the Delaware River main-stem subbasin, Pennsylvania, New Jersey, and New York. Streamflow at these locations is not regulated by reservoirs simulated in HEC-ResSim. 


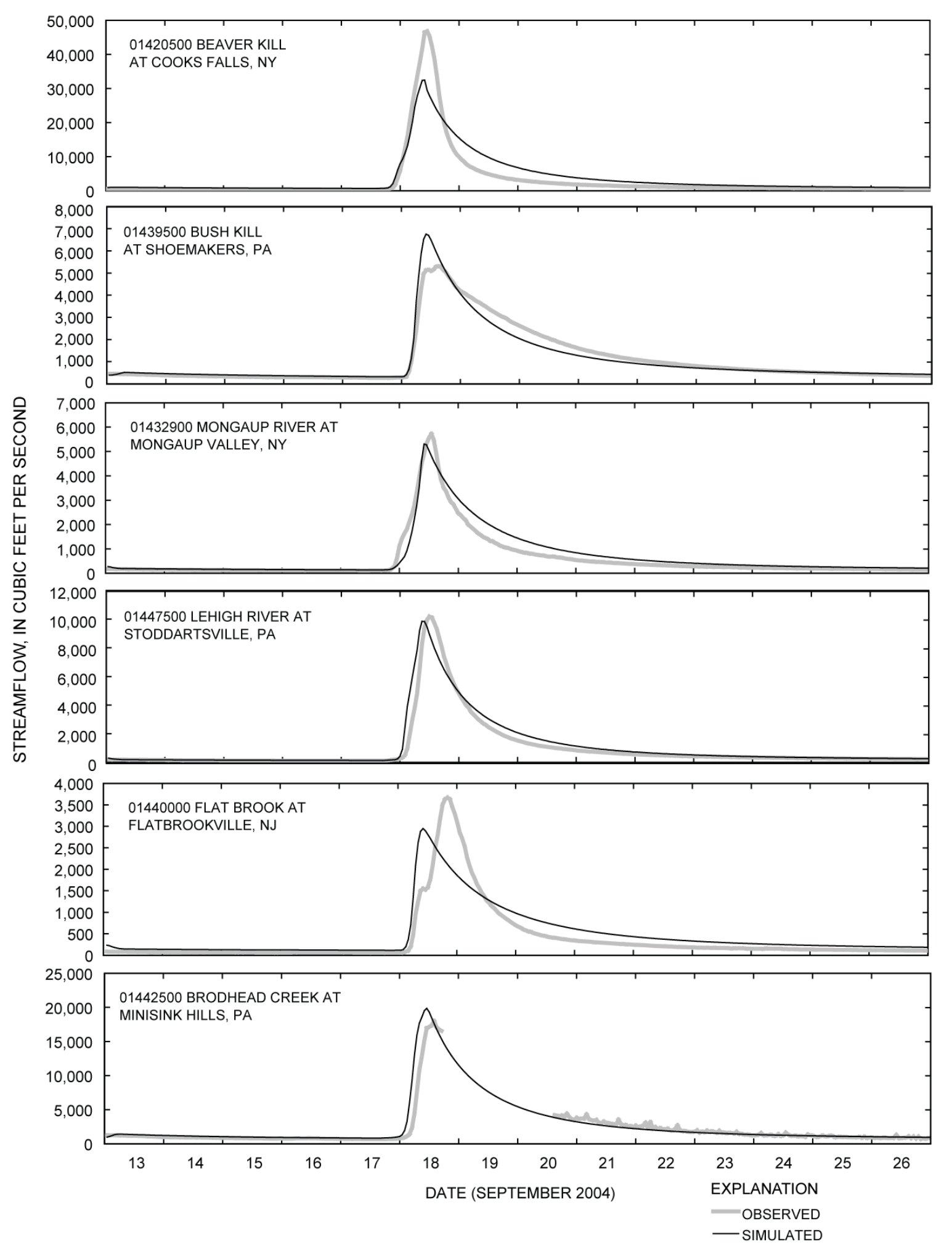

Figure 10. Simulated and observed streamflow, September 13 to 26, 2004, at selected U.S. Geological Survey streamgages in the Delaware River main-stem subbasin, Pennsylvania, New Jersey, and New York. Streamflow at these locations is not regulated by reservoirs simulated in HEC-ResSim. -Continued Observed data affected by backwater removed from Minisink Hills record. 

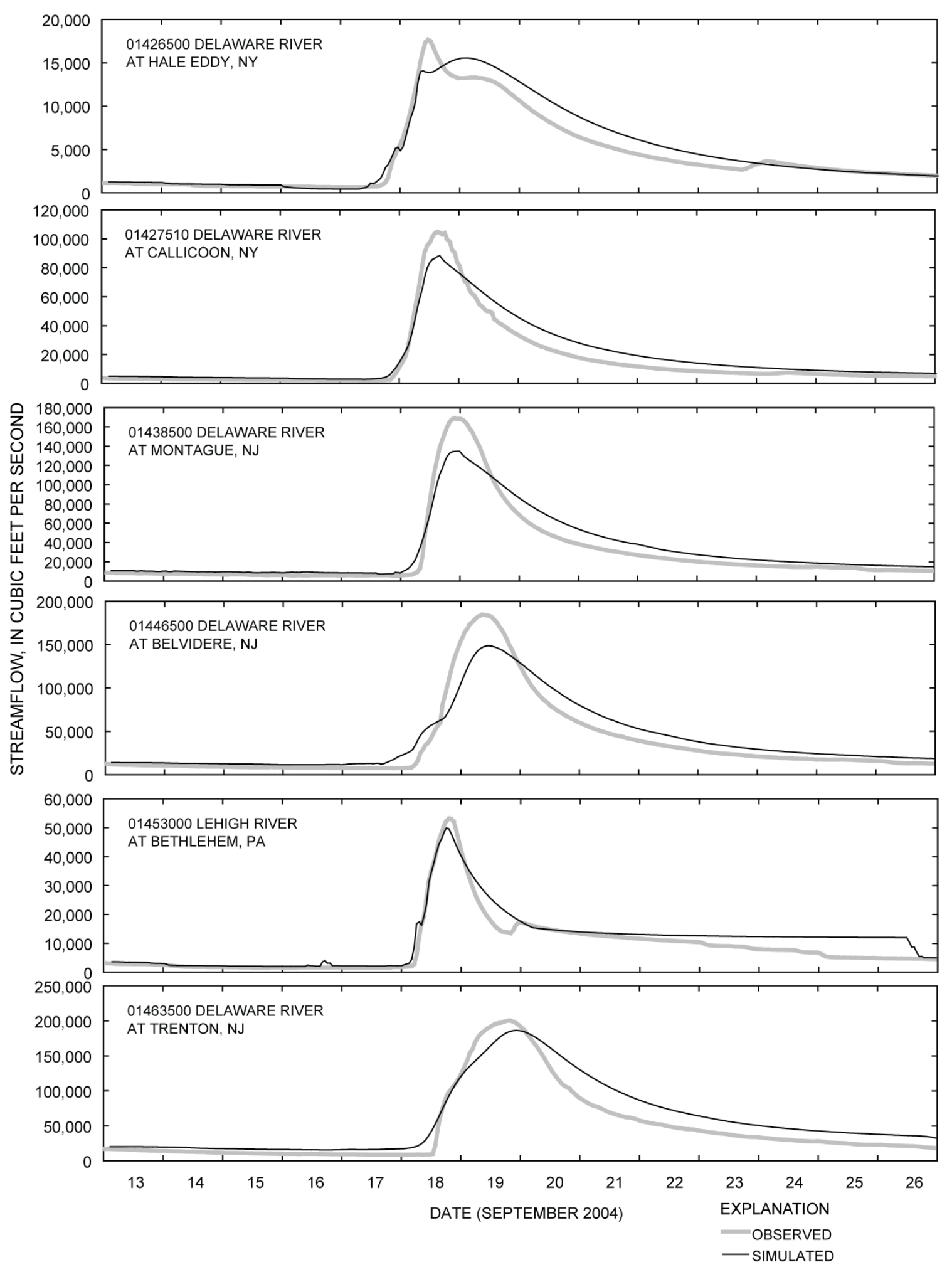

Figure 11. Simulated and observed streamflow, September 13 to 26, 2004, at selected U.S. Geological Survey streamgages below reservoirs in the Delaware River main-stem subbasin, Pennsylvania, New Jersey, and New York. Simulated streamflow is from HEC-ResSim reservoir and routing model using runoff and reservoir inflow from the PRMS model (Joan Klipsch, U.S. Army Corps of Engineers, written commun., May 4, 2009) 


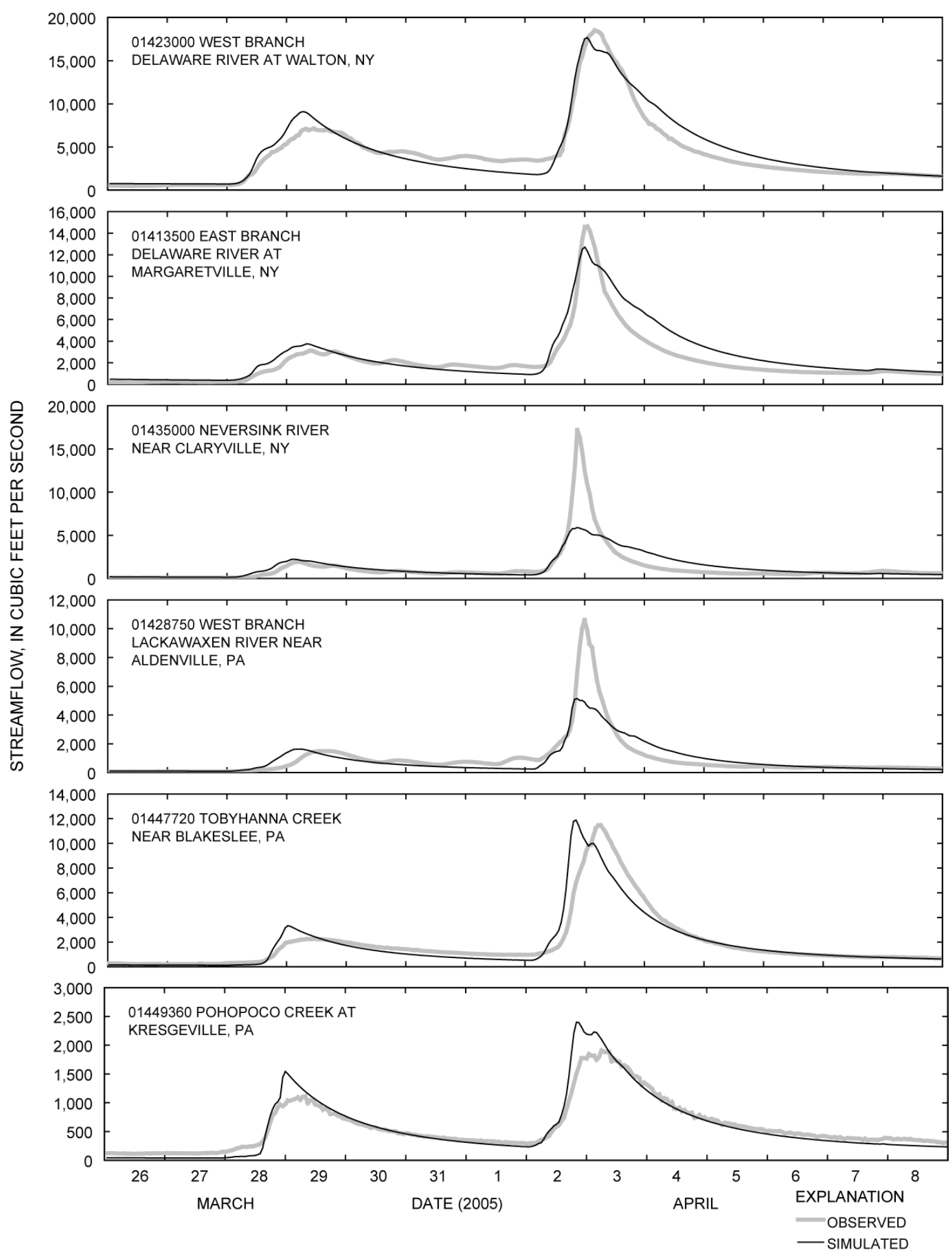

Figure 12. Simulated and observed streamflow, March 26 to April 8, 2005, at selected U.S. Geological Survey streamgages in the Delaware River main-stem subbasin, Pennsylvania, New Jersey, and New York. Streamflow at these locations is not regulated by reservoirs simulated in HEC-ResSim. 


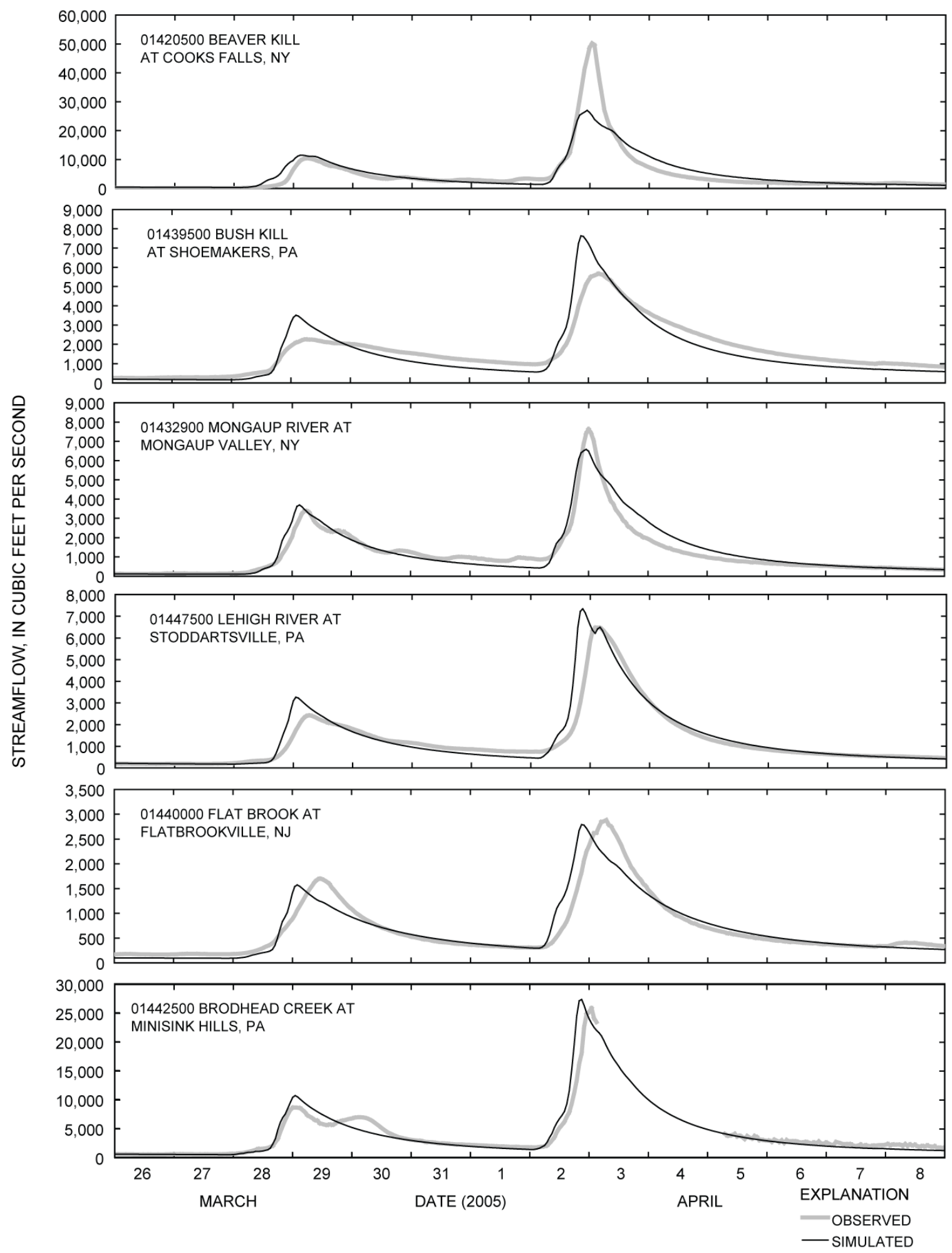

Figure 12. Simulated and observed streamflow, March 26 to April 8, 2005, at selected U.S. Geological Survey streamgages in the Delaware River main-stem subbasin, Pennsylvania, New Jersey, and New York. Streamflow at these locations is not regulated by reservoirs simulated in HEC-ResSim. -Continued Observed data affected by backwater removed from Minisink Hills record. 


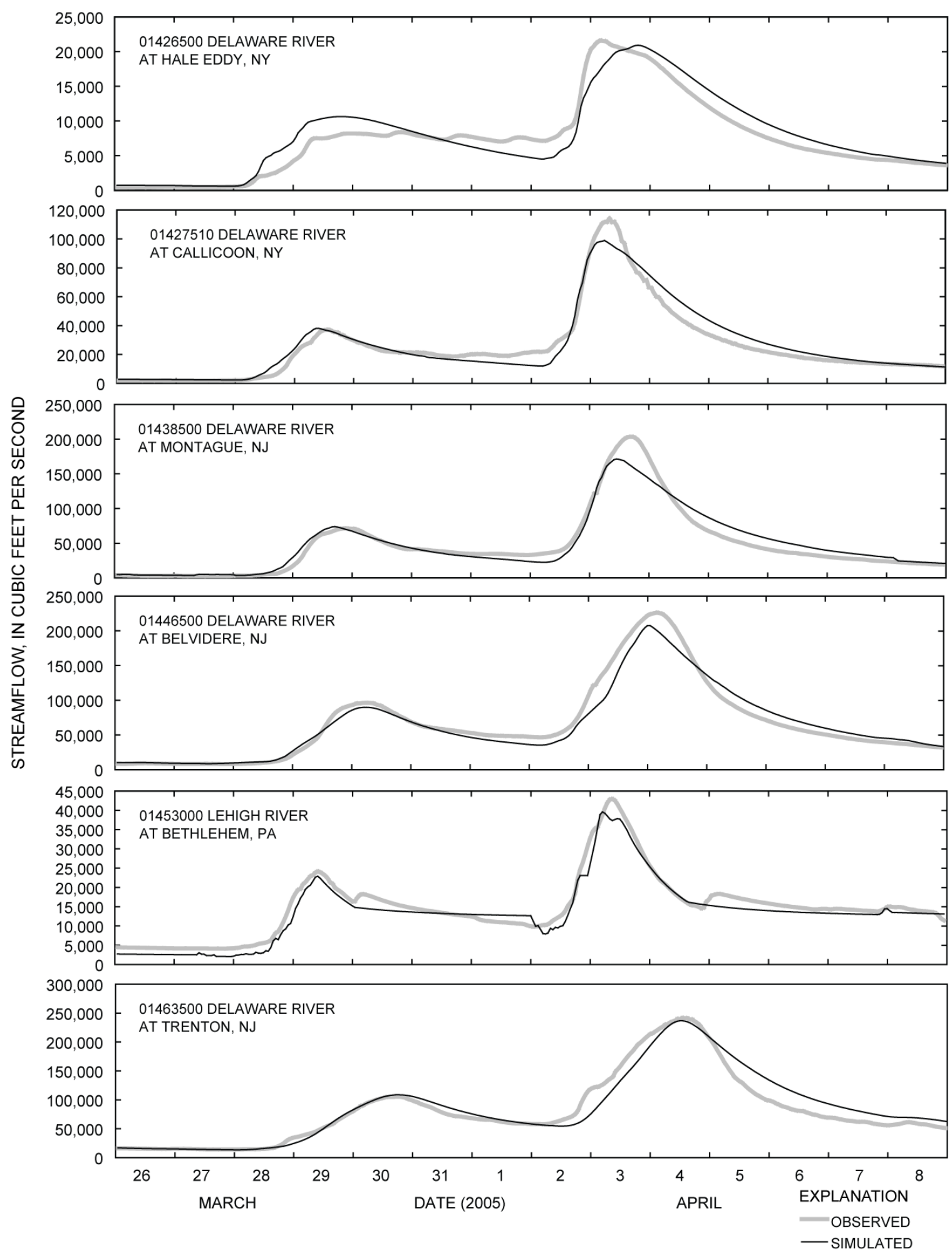

Figure 13. Simulated and observed streamflow, March 26 to April 8, 2005, at selected U.S. Geological Survey streamgages below reservoirs in the Delaware River main-stem subbasin, Pennsylvania, New Jersey, and New York. Simulated streamflow is from HEC-ResSim reservoir and routing model using runoff and reservoir inflow from the PRMS model (Joan Klipsch, U.S. Army Corps of Engineers, written commun., May 4, 2009) 


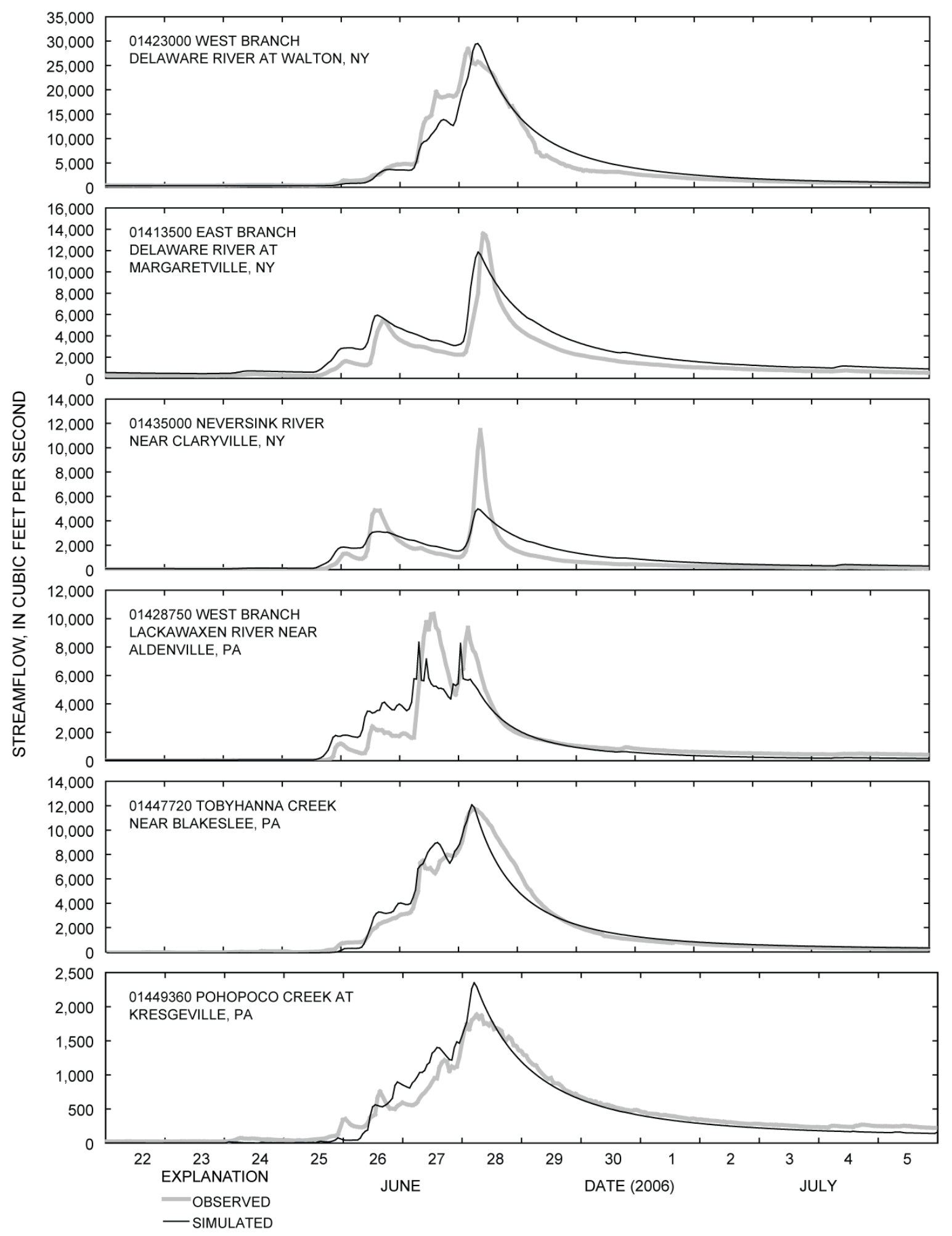

Figure 14. Simulated and observed streamflow, June 22 to July 5, 2006, at selected U.S. Geological Survey streamgages in the Delaware River main-stem subbasin, Pennsylvania, New Jersey, and New York. Streamflow at these locations is not regulated by reservoirs simulated in HEC-ResSim. 


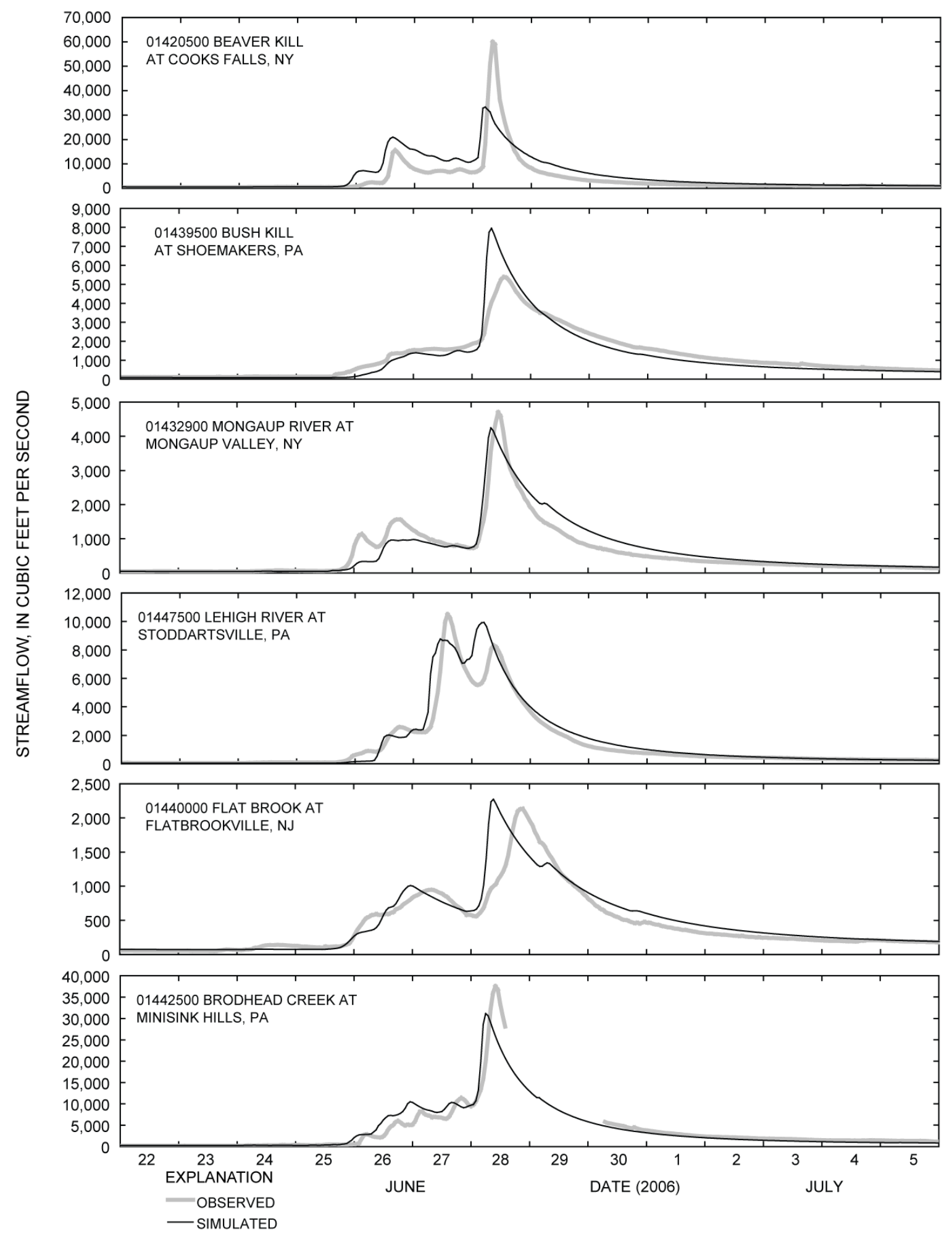

Figure 14. Simulated and observed streamflow, June 22 to July 5, 2006, at selected U.S. Geological Survey streamgages in the Delaware River main-stem subbasin, Pennsylvania, New Jersey, and New York. Streamflow at these locations is not regulated by reservoirs simulated in HEC-ResSim.-Continued Observed data affected by backwater removed from Minisink Hills record. 


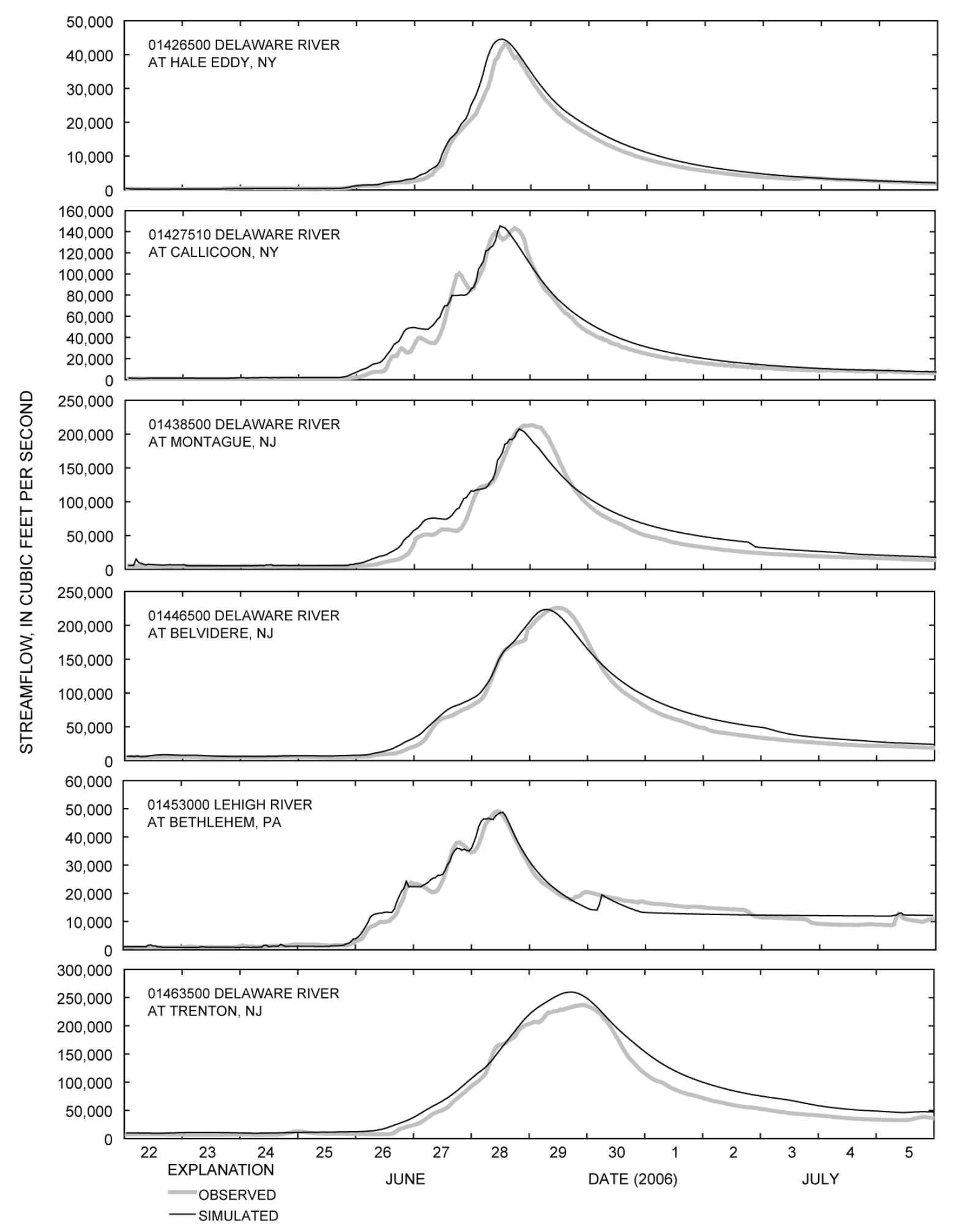

Figure 15. Simulated and observed streamflow, June 22 to July 5, 2006, at selected U.S. Geological Survey streamgages below reservoirs in the Delaware River main-stem subbasin, Pennsylvania, New Jersey, and New York. Simulated streamflows are from HEC-ResSim reservoir and routing model using runoff and reservoir inflow from the PRMS model (Joan Klipsch, U.S. Army Corps of Engineers, written commun., May 4, 2009) 


\section{Limitations}

The PRMS model of the Delaware River subbasin draining to Trenton, N.J., simulates runoff to reservoirs and local runoff for input into the HEC-ResSim model to compare the effects of different watershed conditions on flows in large rivers within the study area during flooding. The model is limited, however, by the following: spatial resolution, data gaps, model simplifications, errors in precipitation and temperature input data, errors in streamflow calibration data, and the focus of calibration on peak flows.

The large model area caused some computational difficulties during discretization and GIS processing. These difficulties limited the minimum size of HRUs and the resolution of the DEM used. Precipitation in the study area is correlated with elevation; higher precipitation amounts are related to higher elevations. Furthermore, the change in elevation, or slope, is a primary factor in runoff characteristics. Hence, discretization with smaller HRUs and more accurate elevations and slopes may improve the simulation results, especially in headwater streams.

Several data gaps exist that affect model accuracy. Stages at the Minisink Hills streamgage are affected by backwater during high-flow events and, hence, cannot be used to estimate discharge in the tributary during these periods. A few other streamgages were inoperative during peak flows because the streamgage equipment was inundated. Substantial portions of the streamflow into many of the major reservoirs in the study area are not measured. Some streamgages, especially on the main-stem Delaware River, are operated as stage-only streamgages, and the associated rating curve to convert stage into discharge is less accurate than at fully maintained streamgages. In addition, missing data and artifacts were identified in climate data, including MPE precipitation.

This model is judged adequate for providing reservoir inflows, local inflows and unregulated tributary flows for input into the HEC-ResSim model to assess the impacts of watershed conditions on flows in the regulated tributaries and main stem of the Delaware River during high-flow events. Other uses of the model may require additional development or calibration. The model calibration focused on time periods before, during, and after the three extreme high-flow events; the model will be less accurate for simulations during other conditions.

\section{Suggestions for Model Application}

Suggested use of the PRMS model is to provide runoff and streamflow information throughout the study area for use in a reservoir-operation model, HEC-ResSim, documented separately. The FloodAnalysis Model, integrating the PRMS and HEC-ResSim models, was developed to be used to evaluate the impacts of both basin hydrology and reservoir operations on downstream flood discharges during the three high-flow events and was developed as a planning tool. Simulation results with existing or historic conditions can be compared to simulation results using alternative conditions, to evaluate the impact of those alternative conditions on downstream flows in large rivers. In this approach, the model errors common to both simulation results have minimal impact on the relative differences between the simulations. This model was not developed as a forecasting tool for realtime prediction of floods on the Delaware River.

The PRMS model provides simulated hydrologic conditions throughout the watershed, as discretized by the model HRUs. An example of the output from the PRMS model is the soil moisture in the watershed, which acts as a reservoir to store and release water (fig. 16). The model also computes incremental runoff for simulated stream segments (fig. 17). These variables change hourly during the storm-mode simulation. Many other model variables can be examined through the model output files and the user interface provided. 

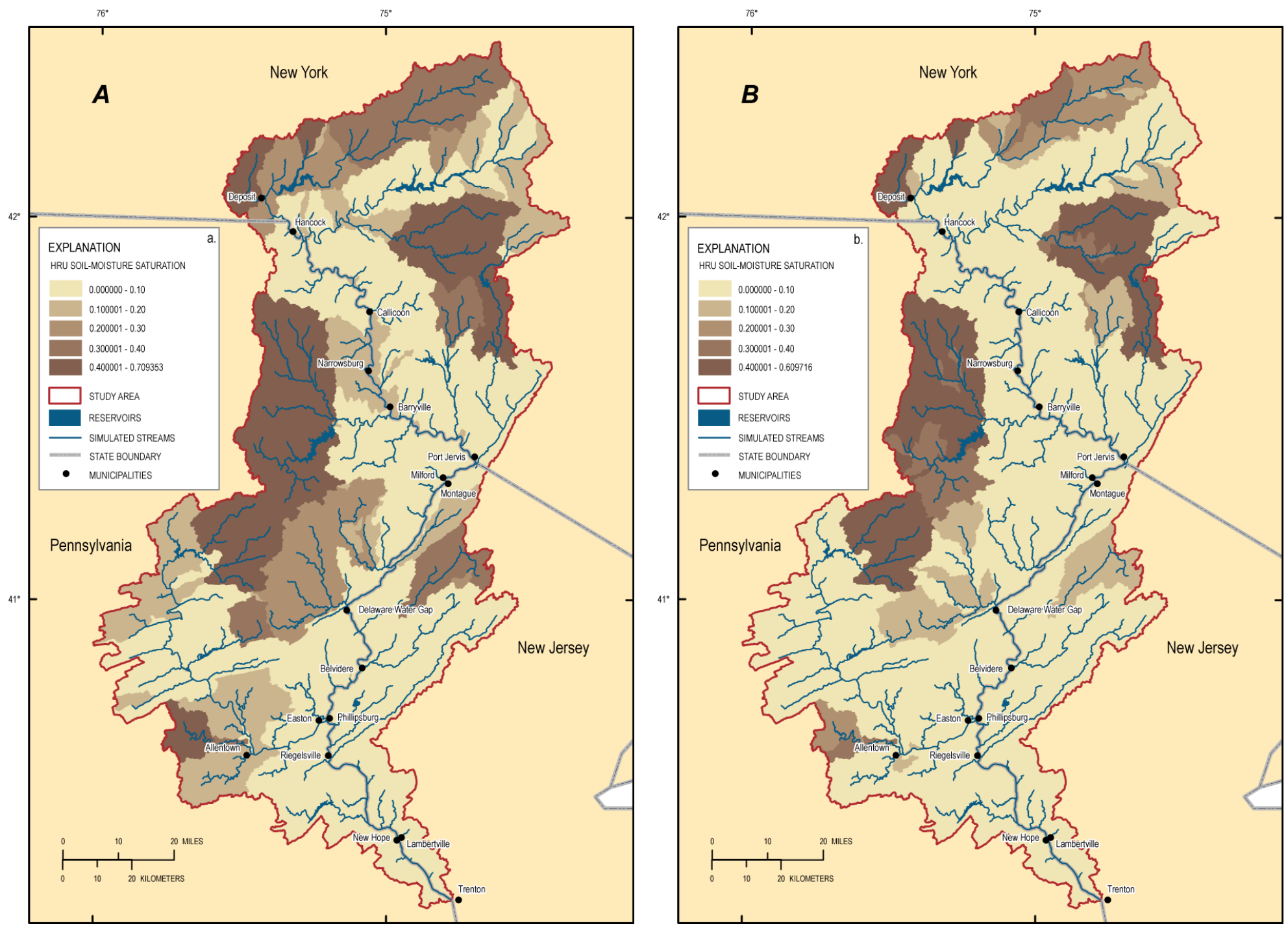

Figure 16. Simulated soil-moisture saturation at noon on A) March 26, 2005, and B) June 23, 2006, for model hydrologic response units (HRUs) for the Delaware River main-stem subbasin, Pennsylvania, New Jersey, and New York. 


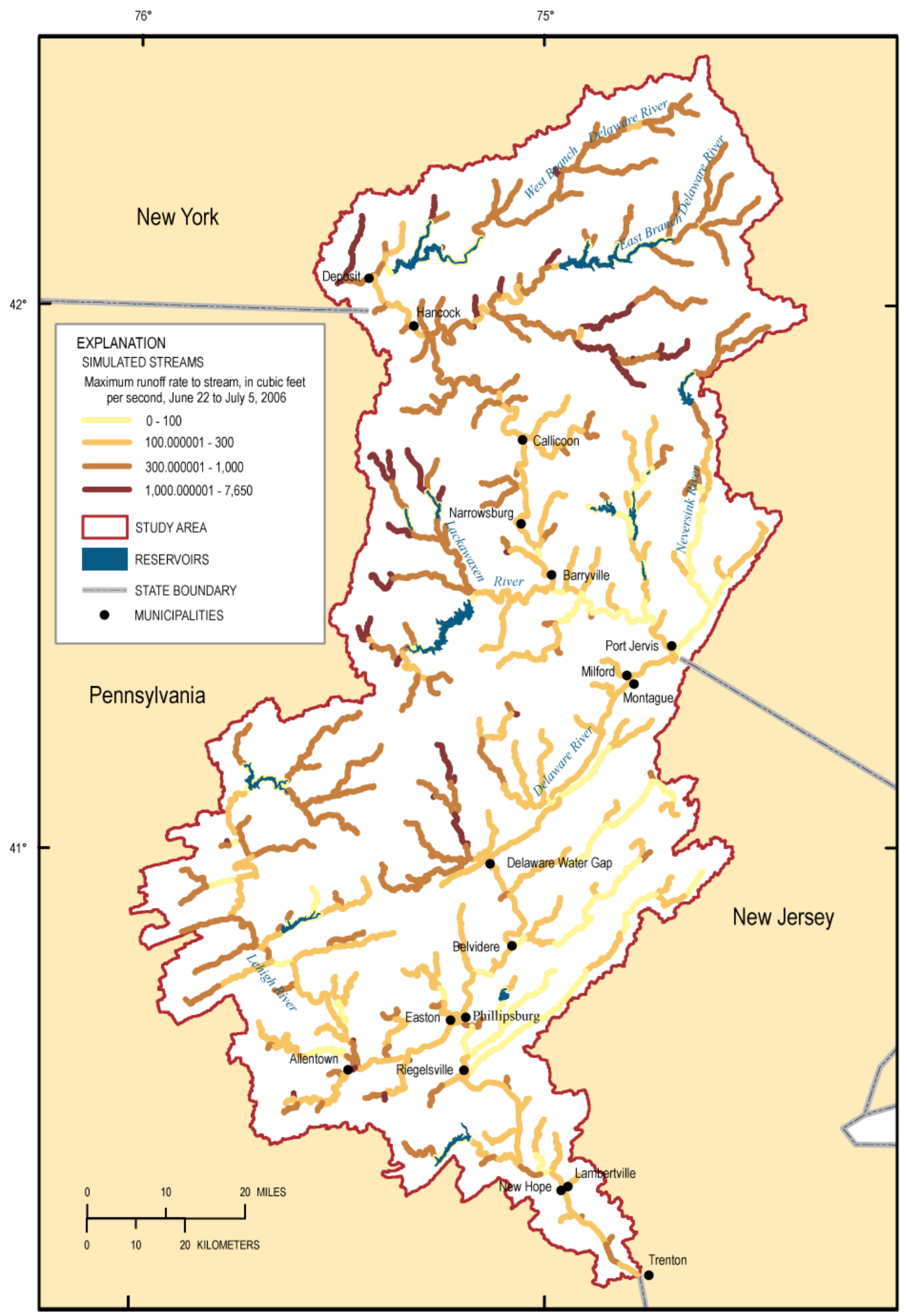

Figure 17. Simulated maximum runoff rate during June 22 to July 5,2006 , to model stream segments for the Delaware River main-stem subbasin, Pennsylvania, New Jersey, and New York. 
The Flood-Analysis Model may be useful as a planning tool to evaluate the effects of watershed conditions on flood discharges on large rivers in the Delaware River main-stem subbasin. The model can be used to predict streamflow under different past climate conditions, provided those are reasonably close to the climate of the calibration events. Model results using different past climate records can help understand the watershed response to different storm events. However, the calibration described in this report focuses on runoff during three flood events. Applications for non-flood events, or for flood events having different conditions than the three events considered here, may require additional calibration.

As a planning tool, the model may also be useful for simulation of the change in high flows for cases with different watershed parameters. To assist with land-use planning, for example, an alternative model could be developed with PRMS model parameters that could be adjusted to account for hypothetical changes in land use. The high flows simulated using such an alternative model could be compared to the calibrated model results, and the differences caused in the model by the changes in land-use parameters could be used to inform land-use planning decisions. However, the alternative or adjusted parameters needed to represent the land-use changes in this example would need to be determined by an expert user, using procedures beyond those developed for this study. The validity of such an application would rest on the validity of the user-specified parameters. In addition, the simulated hydrologic conditions in such an alternative case may extend beyond the conditions used here for model calibration, introducing additional error in the simulation results.

An appropriate use of the model for planning purposes would be to compare model results to model results, as input to make decisions about alternative management of the watershed. For example, an analysis of the effect of land-use change on streamflow would compare the results of model simulations for two different cases of land-use conditions. It would not be appropriate to conduct such an analysis by comparing simulated streamflow, with hypothetical land use, to measured streamflow, because such a comparison would include errors in the simulated streamflow that are present only in the model results. By comparing model results to model results, the impact of the unavoidable model errors on the differences is minimized. This use is similar to the use of the daily flow model OASIS to inform the decision-making process by DRBC (Quinodoz, 2006).

\section{Summary}

To evaluate the impact of reservoir levels and other factors on flooding, the DRBC, USGS, HEC, and NWS developed a Flood-Analysis Model for the Delaware River. The primary components of the model are a rainfall-runoff component (the PRMS model) and a reservoir and streamflow routing component (the HEC-ResSim model). This report describes the rainfall-runoff model component, which uses a modified version of the PRMS software. PRMS is a modular, physically based, distributedparameter modeling system developed to evaluate the impacts of various combinations of precipitation, climate, and land use on surface-water runoff and general basin hydrology. The PRMS model simulates time periods associated with main-stem flooding that occurred in September 2004, April 2005, and June 2006.

The study area was the 6,780- $\mathrm{mi}^{2}$ watershed of the Delaware River in the states of Pennsylvania, New Jersey, and New York that drains to Trenton, N.J. A geospatial database was created for use with a GIS to assist model discretization, determine land-surface characterization, and estimate model parameters. The USGS NED at 100-m resolution was used for model discretization into 452 stream segments and 869 HRUs. In addition, geospatial processing was used to estimate initial model parameters from the DEM and other data layers, including land use. Climate data for point stations were obtained from multiple sources. These sources included daily data for 22 NWS Coop network stations, hourly data for 15 stations from the NCDC, hourly data for 1 station from the NWS Middle Atlantic 
River Forecast Center records, and daily and hourly data for 7 stations operated by the NYCDEP. The NWS radar-based Multisensor Precipitation Estimate data set was used to compute daily precipitation in the study area for 2001-2007 and to compute hourly precipitation for storm periods.

Calibration of the PRMS model was performed using the LUCA model calibration tool, as well as manual adjustments. The general goal of the calibration procedure was to minimize the difference between streamflow measured at USGS streamgages and the corresponding streamflow simulated by the model. Daily streamflow data from 42 USGS streamgages were acquired for use in model calibration. The streamflow data represented areas draining from 20.2 to $6,780 \mathrm{mi}^{2}$. The model was judged to be adequately calibrated for generation of reservoir inflows, local inflows and unregulated tributary flows for input into the HEC-ResSim model to assess the effects of watershed characteristics on regulated tributary and main stem Delaware River flows during floods. Model uncertainty is lower for streamflow on major rivers below reservoirs, and higher for smaller unregulated streams.

The PRMS model simulates runoff and reservoir inflows for input into the HEC-ResSim model to assess the impacts of watershed conditions on flows in the regulated tributaries and main stem of the Delaware River watershed draining to Trenton, N.J. during high flow events. Suggested application of the PRMS model is as a planning tool, in conjunction with the reservoir-simulation component, the HEC-ResSim model, of the Flood-Analysis Model. Differences in simulation results for different model input may be useful in evaluating alternative management of the land and water resources of the basin. Accuracy of the model is limited by the following: spatial resolution, data gaps, model simplifications, errors in precipitation and temperature input data, errors in streamflow calibration data, and the focus of calibration on peak flows.

\section{Acknowledgments}

This work was part of a collaborative project with the Delaware River Basin Commission, the U.S. Army Corps of Engineers, Hydrologic Engineering Center, and NOAAs National Weather Service, Middle Atlantic River Forecast Center. The authors gratefully acknowledge contributing individuals from these agencies, including Amy L. Shallcross, Hernan Quinodoz and Richard Fromuth of DRBC; Joan Klipsch and Marilyn Hurst of HEC; and Joseph Ostrowski of MARFC. Contributions of data used for model development by the following individuals are also gratefully acknowledged: Karen Reavy of DRBC; and Glenn Horton of New York City Department of Environmental Protection. The authors gratefully acknowledge the following USGS staff contributing to this work: R. Edward Hickman and Donald E. Rice for compilation of streamflow and map information; Roland Viger for assistance and guidance for model parameterization and discretization; and David M. Bjerklie for assistance and guidance for model parameterization. 


\section{References Cited}

Alley, W.M., and Veenhuis, J.E., 1983, Effective impervious area in urban runoff modeling: Journal of Hydraulic Engineering, v. 109, no. 2, p. 313-319.

Anderson, E.A., 2006, Snow accumulation and ablation model - SNOW-17: in Chap. II.2 of NOAA's National Weather Service River Forecast System User Manual, 61 p., accessed November 18, 2008, at http://www.weather.gov/oh/hrl//nwsrfs/users_manual/part2/_pdf/22snow17.pdf.

Ayers, M.A., Wolock, D.M., McCabe, G.J., Hay, L.E., and Tasker, G.D., 1994, Sensitivity of water resources in the Delaware River basin to climate variability and change: U.S. Geological Survey Water-Supply Paper 2422, 42 p. (Also available at http://pubs.usgs.gov/wsp/wsp_2422/.)

Battaglin, W.A., Hay, L.E., Parker, R.S., and Leavesley, G.H., 1993, Applications of a GIS for modeling the sensitivity of water resources to alterations in climate in the Gunnison River basin, Colorado: Journal of the American Water Resources Association, v. 29, no. 6, p. 1021-1028. (Also available at $h t t p: / / d x . d o i . o r g / 10.1111 / j .1752-1688.1993 . t b 03265 . x$.)

Berris, S.N., Hess, G.W., and Bohman, L.R., 2001, River and reservoir operation model, Truckee River basin, California and Nevada, 1998: U.S. Geological Survey Water-Resources Investigations Report 01-4017, 138 p. (Also available at http://pubs.usgs.gov/wri/wri014017/. )

Bilbao, J., Miguel, A., and Kambezidis, H., 2002, Air temperature model evaluation in the North Mediterranean Belt area: Journal of Applied Meteorology, v. 41, p. 872-884.

Black, P.E., 1996, Watershed hydrology: Chelsea, Mich., Ann Arbor Press, Inc., 449 p.

Bovee, K.D., Waddle, T.J., Bartholow, J., and Burris, L., 2007, A decision support framework for water management in the upper Delaware River: U.S. Geological Survey Open-File Report 2007-1172, 122 p. (Also available at http://pubs.er.usgs.gov/usgspubs/ofr/ofr20071172 .)

Brooks, L.T., 2005, Flood of September 18-19, 2004 in the upper Delaware River basin, New York: U.S. Geological Survey Open-File Report 2005-1166, 130 p. (Also available at http://ny.water.usgs.gov/pubs/of/of051166/.)

Chepiga, Mary, Colarullo, S.J., and Fischer, J.M., 2004, Preliminary analysis of estimated total nitrogen and total phosphorus loads and factors affecting nutrient distribution within the Delaware River basin [abs.], in Proc. of the American Water Resources Assoc. 2004 Spring Specialty Conf. - Geographic Information Systems (GIS) and Water Resources III: American Water Resources Association, May 17-19, 2004, Nashville, Tenn.

Clark, M.P., and Hay, L.E., 2004, Use of medium-range numerical weather prediction model output to produce forecasts of streamflow: Journal of Hydrometeorology, v. 5, no. 1, p. 15-32.

DeGaetano, A.T., Eggleston, K.L., and Knapp, W.W., 1993, Daily solar radiation estimates for the northeastern Unites States: Northeast Regional Climate Center Research Series, Publications No. RR 93-4, 7 p.

Delaware River Basin Commission, 2008a, State of the Delaware River Basin Report: accessed December 8, 2008, at http://www.state.nj.us/drbc/SOTB/.

Delaware River Basin Commission, 2008b, Recent flooding events in the Delaware River basin: accessed December 10, 2008, at http://www.state.nj.us/drbc/Flood_Websitelevents.htm/.

Duan, Q., Sorooshian, S., and Gupta, V.K., 1993, A shuffled complex evolution approach for effective and efficient global minimization: Journal of Optimization Theory and its Applications, v. 76, no. 3, p. 501-521.

Emerson, D.G., 1991, Documentation of a heat and water transfer model for seasonally frozen soils with application to a precipitation-runoff model: U.S. Geological Survey Open-File Report 91-462, 92 p. (Also available at http://pubs.er.usgs.gov/usgspubs/ofr/ofr91462. ) 
Erbs, D.G., Klein, S.A., and Beckman, W.A., 1983, Estimation of degree day and ambient temperature bin data from monthly-average temperatures: ASHRAE Journal, v. 26, p. 60-65.

Fischer, J.M., 1999, Delaware River basin: U.S. Geological Survey Fact-Sheet 056-99, 6 p. (Also available at http://pubs.er.usgs.gov/usgspubs/fs/fs05699 .)

Fischer, J.M., Riva-Murray, Karen, Hickman, R.E., Chichester, D.C., Brightbill, R.A., Romanok, K.M., and Bilger, M.D., 2004, Water quality in the Delaware River basin, Pennsylvania, New Jersey, New York, and Delaware, 1998-2001: U.S. Geological Survey Circular 1227, 48 p. (Also available at http://pubs.usgs.gov/circ/2004/1227/.)

Flippo, H.N., Jr., and Madden, T.M., Jr., 1994, Calibration of a streamflow-routing model for the Delaware River and its principal tributaries in New York, New Jersey, and Pennsylvania: U.S. Geological Survey Water-Resources Investigations Report 93-1460, 31 p. (Also available at http://pubs.er.usgs.gov/usgspubs/wri/wri934160 .)

Fulp, T.J., Vickers, W.B., Williams, B., and King, D.L., 1995, Decision support for water resources management in the Colorado River region, in Ahuja, L., Leppert, J., Rojas, K., and Seely, E., Workshop on computer applications in water management: Fort Collins, Colo., Colorado State University, Joint Publication of Great Plains Agricultural Council Publication 154 and Colorado Water Resources Research Institute No. 79, p. 24-27.

Hay, L.E., and Clark, M.P., 2003, Use of statistically and dynamically downscaled atmospheric model output for hydrologic simulations in three mountainous basins in the western United States: Journal of Hydrology, v. 282, p. 56-75.

Hay, L.E., Clark, M.P., and Leavesley, G.H., 2000, Use of atmospheric forecasts in hydrologic models. Part Two-Case study, in Kane, D.L., ed., Water resources in extreme environments: Middleburg, Va., American Water Resources Association, p. 221-226.

Hay, L.E., Clark, M.P., Wilby, R.L., Gutowski, W.J., Leavesley, G.H., Pan, Z., Arritt, R.W., and Takle, E.S., 2002, Use of regional climate model output for hydrologic simulations: Journal of Hydrometeorology, v. 3, p. 571-590.

Hay, L.E., Leavesley, G.H., Clark, M.P., Markstrom, S.L., Viger, R.J., and Umemoto, M., 2006, Step wise, multiple objective calibration of a hydrologic model for a snowmelt dominated basin: Journal of the American Water Resources Association, v. 42, no. 4, p. 877-890.

Hay, L.E., and Umemoto, M., 2007, Multiple-objective step-wise calibration using Luca: U.S. Geological Survey Open-File Report 2006-1323, 25 p. (Also available at http://pubs.usgs.gov/of/2006/1323/.)

Hay, L.E., Wilby, R.L., and Leavesley, G.H., 2000, A comparison of delta change and downscaled GCM scenarios for three mountainous basins in the United States: Journal of the American Water Resources Association, v. 36, no. 2, p. 387-397.

Hirsch, R.M., 1981, Estimating probabilities of reservoir storage for the upper Delaware River basin: U.S. Geological Survey Open-File Report 81-478, 20 p.

Hoopes, B.C., ed., 2004, User's manual for the National Water Information System of the U.S. Geological Survey (USGS): U.S. Geological Survey Open-File Report 2004-1238, 262 p.

HydroLogics, Inc., 2002, Modeling the Delaware River Basin with OASIS: Columbia, Md., variously paged.

Jenner, C.B., and Lins, H.F., 1991, Climatic atlas of the Delaware River basin: U.S. Geological Survey Professional Paper 1392, 127 p. (Also available at http://pubs.er.usgs.gov/usgspubs/pp/pp1392.)

Jensen, M.E., and Haise, H.R., 1963, Estimating evapotranspiration from solar radiation: Proceedings of the American Society of Civil Engineers, Journal of Irrigation and Drainage, v. 89, no. IR4, p. 15-41. 
Jensen, M.E., Rob, D.C.N., and Franzoy, C.E., 1969, Scheduling irrigations using climate-crop-soil data, in National Conference on Water Resources Engineering of the American Society of Civil Engineers, New Orleans, La. [Proceedings], p. 20.

Jeton, A.E., 2000, Precipitation-runoff simulations for the upper part of the Truckee River basin, California and Nevada: U.S. Geological Survey Water-Resources Investigations Report 99-4282, 41 p. (Also available at http://pubs.er.usgs.gov/usgspubs/wri/wri994282.)

Jeton, A.E., Dettinger, M.D., and Smith, J.L., 1996, Potential effects of climate change on streamflow, eastern and western slopes of the Sierra Nevada, California and Nevada: U.S. Geological Survey Water-Resources Investigations Report 95-4260, 9 p. (Also available at http://pubs.er.usgs.gov/usgspubs/wri/wri954260.)

Kalin, Latif, and Hantush, M.M., 2006, Hydrologic modeling of an eastern Pennsylvania watershed with NEXRAD and rain gauge data: Journal of Hydrologic Engineering, v. 11, no. 6, p. 555-569.

Koczot, K.M., Jeton, A.E., McGurk, Bruce, and Dettinger, M.D., 2005, Precipitation-runoff processes in the Feather River basin, northeastern California, and streamflow predictability, water years 1971-97: U.S. Geological Survey Scientific Investigations Report 2004-5202, 92 p. (Also available at http://pubs.usgs.gov/sir/2004/5202/. )

Leavesley, G.H., Lichty, R.W., Troutman, B.M., and Saindon, L.G., 1983, Precipitation-runoff modeling system-User's manual: U.S. Geological Survey Water-Resources Investigations Report 834238, 207 p. (Also available at http://pubs.er.usgs.gov/usgspubs/wri/wri834238. )

Leavesley, G.H., Markstrom, S.L., Viger, R.J., and Hay, L.E., 2005, USGS Modular Modeling System (MMS) - Precipitation-runoff modeling system (PRMS) MMS-PRMS, in Singh, V., and Frevert, D., eds., Watershed models: Boca Raton, Fla., CRC Press, p. 159-177. (Also available at ftp://brrftp.cr.usgs.gov/pub/mows/software/oui_and_mms_s/prms_chap.pdf .)

Leavesley, G.H., Restrepo, P.J., Markstrom, S.L., Dixon, M., and Stannard, L.G., 1996, The Modular Modeling System (MMS): User's manual: U.S. Geological Survey Open File Report 96-151, 142 p.

Leavesley, G.H., and Stannard, L.G., 1995, The precipitation-runoff modeling system-PRMS, in Singh, V.P., ed., Computer models of watershed hydrology: Highlands Ranch, Colo., Water Resource Publications, p. 281-310.

Markstrom, S.L., and Koczot, K.M., 2008, User's manual for the object user interface (OUI)—An environmental resource modeling framework: U.S. Geological Survey Open-File Report 2008-1120, 39 p. (Also available at http://pubs.usgs.gov/of/2008/1120/ .)

Markstrom, S.L., Niswonger, R.G., Regan, R.S., Prudic, D.E., and Barlow, P.M., 2008, GSFLOWCoupled ground-water and surface-water flow model based on the integration of the PrecipitationRunoff Modeling System (PRMS) and the Modular Ground-Water Flow Model (MODFLOW-2005): U.S. Geological Survey Techniques and Methods, book 6, chap. D1, 240 p. (Also available at http://pubs.usgs.gov/tm/tm6dl/ .)

Mastin, M.C., and Vaccaro, J.J., 2002, Watershed models for decision support in the Yakima River basin, Washington: U.S. Geological Survey Open-File Report 2002-404, 47 p. (Also available at http://pubs.usgs.gov/of/2002/ofr02404/. )

Middle Atlantic River Forecast Center, 2006 (August), Model simulations for the Upper Delaware River basin flooding of April, 2005: National Oceanic and Atmospheric Administration, National Weather Service, accessed October 2, 2008, at http://www.state.nj.us/drbc/Flood_Website/NWSResSimRPTAug2006.pdf .

Middle Atlantic River Forecast Center, 2007 (August; revised September 13, 2007), Reservoir simulations for the Delaware River basin flood of April, 2005: National Oceanic and Atmospheric 
Administration, National Weather Service, accessed October 2, 2008, at http://www.state.nj.us/drbc/Flood_Website/NWSJune2006Flood_Rev9-13-07_FinalRpt.pdf .

Miller, D.A., and White, R.A., 1998, A conterminous United States Multi-Layer Soil Characteristics Data Set for regional climate and hydrology modeling: Earth Interactions, v. 2 (1998), Paper no. 2 , accessed December 1, 2008, at http://ams.allenpress.com/archive/1087-3562/2/2/pdf/i1087-3562-2-21.pdf .

Multi-Resolution Land Characteristics Consortium (MRLC), 2001, National land cover database: accessed October 1, 2007, at http://www.mrlc.gov/nlcd.php .

National Climatic Data Center, 2007, Quality controlled local climatological data: accessed June 18, 2008, at http://cdo.ncdc.noaa.gov/qclcd/QCLCD?prior $=N$.

National Climatic Data Center, 2008, Java NEXRAD Tools: accessed July 22, 2008, at http://www.ncdc.noaa.gov/oa/radar/jnx/jnt-install.php .

National Renewable Energy Laboratory, 1992, National solar radiation database 1961-1990: accessed August 15, 2007, at http://rredc.nrel.gov/solar/old_data/nsrdb/1961-1990/.

National Renewable Energy Laboratory, 2007, National solar radiation database 1991-2005 update: accessed July 19, 2007, at http://rredc.nrel.gov/solar/old_data/nsrdb/1991-2005/.

National Weather Service, Hydrology Laboratory, NOAA, 2009, WSR-88D Rainfall Estimation, Publications and Papers: accessed March 4, 2009, at http://www.nws.noaa.gov/oh/hrl/papers/papers.htm\#wsr88d.

Natural Resources Conservation Service, 2006, U.S. General Soil Map (STATSGO2): Natural Resources Conservation Service, accessed January 26, 2008, at http://soils.usda.gov/survey/geography/statsgo/.

New Jersey Department of Environmental Protection, 1996, Bedrock geology for New Jersey: Trenton, N.J., New Jersey Geographic Information System CDROM Series 1, 1996, Volume 1, 2, and 3.

New York State Museum/New York Geological Survey, 1999, Statewide bedrock geology: accessed October 1, 2007, at http://www.nysm.nysed.gov/gis .

Olson, S.A., 2002, Flow-frequency characteristics of Vermont streams: U.S. Geological Survey WaterResources Investigations Report 2002-4238, 47 p. (Also available at http://pubs.usgs.gov/wri/wrirO24238/.)

Parker, G.G., Hely, A.G., Keighton, F.H., Olmsted, F.H., and others, 1964, Water resources of the Delaware River basin: U.S. Geological Survey Professional Paper 381, 200 p. (Also available at http://pubs.er.usgs.gov/usgspubs/pp/pp381 .)

Paulachok, G.N., Krejmas, B.E., and Soden, H.L., 2000, Hydrologic aspects of the 1998-99 drought in the Delaware River basin: U.S. Geological Survey Water-Resources Investigations Report 2000-4112, $29 \mathrm{p}$.

Pennsylvania Department of Conservation and Natural Resources, 2001, Digital bedrock geology of Pennsylvania: accessed October 1, 2007, at http://www.dcnr.state.pa.us/topogeo/mapl/bedmap.aspx . Quinodoz, H.A., 2006, Reservoir operations and flow modeling to support decision making in the Delaware River basin [abs.]: EOS Transactions of the American Geophysical Union, v. 87, no. 52, Fall Meeting Supplement, Abstract H41D-0441, Washington, D.C.

Rankl, J.G., 1987, Analysis of sediment production from two small semiarid basins in Wyoming: U.S. Geological Survey Water-Resources Investigations Report 85-4314, 27 p. (Also available at http://pubs.er.usgs.gov/usgspubs/wri/wri854314 .)

Rantz, S.E., and others, 1982, Measurement and computation of streamflow: U.S. Geological Survey Water-Supply Paper 2175, v. 2, 631 p. (Also available at http://pubs.usgs.gov/wsp/wsp2175/.) 
Reed, T.J., and Protz, A.R., 2007, Flood of April 2-4, 2005, Delaware River main stem from Port Jervis, New York, to Cinnaminson, New Jersey: U.S. Geological Survey Scientific Investigations Report 2007-5067, 57 p. (Also available at http://pubs.usgs.gov/sir/2007/5067/ .)

Roland, M.A., and Stuckey, M.H., 2007, Analysis of flood-magnitude and flood-frequency data for streamflow-gaging stations in the Delaware and North Branch Susquehanna River basins in Pennsylvania: U.S. Geological Survey Open-File Report 2007-1235, 22 p. (Also available at http://pubs.usgs.gov/of/2007/1235/. )

Sauer, V.B., 2002, Standards for the analysis and processing of surface-water data and information using electronic methods: U.S. Geological Survey Water-Resources Investigations Report 01-4044, 92 p. (Also available at $h t t p: / / p u b s . e r . u s g s . g o v / u s g s p u b s / w r i / w r i 20014044$. )

Schopp, R.D., and Firda, G.D., 2008, Flood magnitude and frequency of the Delaware River in New Jersey, New York, and Pennsylvania: U.S. Geological Survey Open-File Report 2008-1203, 9 p. (Also available at http://pubs.usgs.gov/of/2008/1203/. )

Sloto, R.A., and Buxton, D.E., 2005, Water budgets for selected watersheds in the Delaware River basin, eastern Pennsylvania and western New Jersey: U.S. Geological Survey Scientific Investigations Report 2005-5113, 45 p. (Also available at http://pubs.usgs.gov/sir/2005/5113/. )

Soil Survey Staff, 1994, State Soil Geographic Database (STATSGO) collection for the conterminous United States: U.S. Department of Agriculture, Natural Resources Conservation Service, National Soil Survey Center, Lincoln, Neb., CD-ROM.

Steuer, J.J., and Hunt, R.J., 2001, Use of a watershed-modeling approach to assess hydrologic effects of urbanization, North Fork Pheasant Branch basin near Middleton, Wisconsin: U.S. Geological Survey Water-Resources Investigations Report 2001-4113, 49 p. (Also available at http://pubs.er.usgs.gov/usgspubs/wri/wri014113 .)

Suro, T.P., and Firda, G.D., 2006, Flood of April 2-3, 2005, Neversink River basin, New York: U.S. Geological Survey Open-File Report 2006-1319, 98 p. (Also available at http://pubs.usgs.gov/of/2006/1319/.)

Suro, T.P., Firda, G.D. and Szabo, C.O. 2009, Flood of June 26-29, 2006, Mohawk, Delaware, and Susquehanna River Basins, New York: U.S. Geological Survey Open-File Report 2009-1063, 354 p. (Available at http://pubs.usgs.gov/ofr/2009/1063 .)

Sutherland, R.C., 1995, Methodology for estimating the effective impervious area of urban watersheds: Watershed Protection Techniques, v. 2, no. 1, p. 282-284, accessed November 5, 2009, at http://pacificwr.com/Publications/Estimating_EIA.pdf .

Sutherland, R.C., 2005, Impervious area assumptions used in hydrologic modeling of CWS watersheds: Pacific Water Resources, Inc., Technical Memorandum, August 30, 2005, Beaverton, Oregon, 9 p.

Tolson, B.A., and Shoemaker, C.A., 2007, Cannonsville Reservoir watershed SWAT2000 model development, calibration, and validation: Journal of Hydrology, v. 337, p. 68-86.

U.S. Army Corps of Engineers, Hydrologic Engineering Center, 2006, HEC-DSSVue, HEC Data storage system visual utility engine, User's manual version 1.2 revised: accessed December 3, 2008, at http://www.hec.usace.army.mil/software/hec-dss/documents/CompleteManual.pdf .

U.S. Army Corps of Engineers, Hydrologic Engineering Center, 2007, HEC-ResSim Reservoir simulation system, User's manual version 3.0: accessed December 3, 2008, at http://www.hec.usace.army.mil/software/hec-ressim/documentation/HECResSim_30_UsersManual.pdf.

U.S. Geological Survery, 1992a, Watershed Modeling - grnampt_infil_prms.f: accessed February 12, 2009, at http://wwwbrr.cr.usgs.gov/projects/SW_MoWS/software/oui_and_mms_s/prms_files/ grnampt_infil_prms.shtml. 
U.S. Geological Survery, 1992b, Watershed Modeling - krout_chan_prms.f: accessed February 12, 2009, at http://wwwbrr.cr.usgs.gov/projects/SW_MoWS/software/oui_and_mms_s/prms_files/ krout_chan_prms.shtml.

U.S. Geological Survery, 1992c, Watershed Modeling - krout_chan_ofpl_prms.f: accessed February 12, 2009, at http://wwwbrr.cr.usgs.gov/projects/SW_MoWS/software/oui_and_mms_s/prms_files/ krout_ofpl_prms.shtml.

U. S. Geological Survey, 2007a, National Elevation Database: accessed October 1, 2007, at http://ned.usgs.gov .

U.S. Geological Survery, 2007b, Watershed Modeling - strmflow_subbasin.f: accessed February 12, 2009, at http://wwwbrr.cr.usgs.gov/projects/SW_MoWS/software/oui_and_mms_s/prms_files/ strmflow_subbasin.shtml.

U.S. Geological Survey, 2008a, Downsizer: accessed March 19, 2008, at http://wwwbrr.cr.usgs.gov/projects/SW_MoWS/software/downsizer_s/downsizer.shtml .

U.S. Geological Survey, 2008b, Summary of June 28-29, 2006 flooding in the New Jersey part of the Delaware River basin: accessed December 10, 2008, at http://nj.usgs.gov/special/flood0606/.

Vaccaro, J.J., 1992, Sensitivity of groundwater recharge estimates to climate variability and change, Columbia Plateau, Washington: Journal of Geophysical Research, v. 97, no. D3, p. 2821-2833.

Viger, R.J., and Leavesley, G.H., 2007, The GIS Weasel user's manual: U.S. Geological Survey Techniques and Methods, book 6, chap. B4, 201 p. (Also available at http://pubs.usgs.gov/tm/2007/06B04/ .)

Vining, K.C., 2002, Simulation of streamflow and wetland storage, Starkweather Coulee subbasin, North Dakota, water years 1981-98: U.S. Geological Survey Water-Resources Investigations Report 02-4113, 28 p. (Also available at http://nd.water.usgs.gov/pubs/wri/wri024113/.)

Yates, D.N., Warner, T.T., and Leavesley, G.H., 2000, Prediction of a flash flood in complex terrain. Part II-A comparison of flood discharge simulations using rainfall input from radar, a dynamic model, and an automated algorithmic system: Journal of Applied Meteorology, v. 39, no. 6, p. 815825.

Yeung, C.W., 2005, Rainfall-runoff and water-balance models for management of the Fena Valley Reservoir, Guam: U.S. Geological Survey Scientific Investigations Report 2004-5287, 52 p. (Also available at $h t t p: / / p u b s . u s g s . g o v /$ sir/2004/5287/. )

Ward-Garrison, C., Markstrom, S.L., and Hay, L.E., 2009, Downsizer-A graphical user interfacebased application for browsing, acquiring, and formatting time-series data for hydrologic modeling: U.S. Geological Survey Open-File Report 2009-1166, 27 p. (Also available at http://pubs.usgs.gov/of/2009/1166/ .)

Wilby, R.L., Hay, L.E., and Leavesley, G.H., 1999, A comparison of downscaled and raw GCM output - Implications for climate change scenarios in the San Juan River basin, Colorado: Journal of Hydrology, v. 225, p. 67-91. 


\section{Appendix - Documentation of PRMS Modules Modified for This Study}

There are three modules that were created or modified for this study. These modules are documented herein. 


\section{Module climate_hru_prms.f}

\section{NAME}

climate_hru_prms.f

\section{SPECIAL FEATURES}

This is a new module.

\section{MODULE PROCESS (TYPE)}

Climate

\section{DEFINITION}

Reads input precipitation and temperature variables from the designated data files.

\section{KEYWORDS}

\section{CREATION DATE}

January 2009

\section{PARAMETERS DECLARED}

Tmax_allsnow - Monthly maximum air temperature at which precipitation is all snow for the HRU.

Hru subbasin - Index of subbasin number for each HRU.

Hru_area - Area of each HRU. being rain

Tmax_allrain - Monthly minimum air temperature at an HRU that results in all precipitation during a day

Rain_sub_adj - Monthly factor as a decimal fraction used to adjust rain values, by subbasin.

Snow_sub_adj - Monthly factor as a decimal fraction used to adjust snow values, by subbasin.

\section{VARIABLES DECLARED}

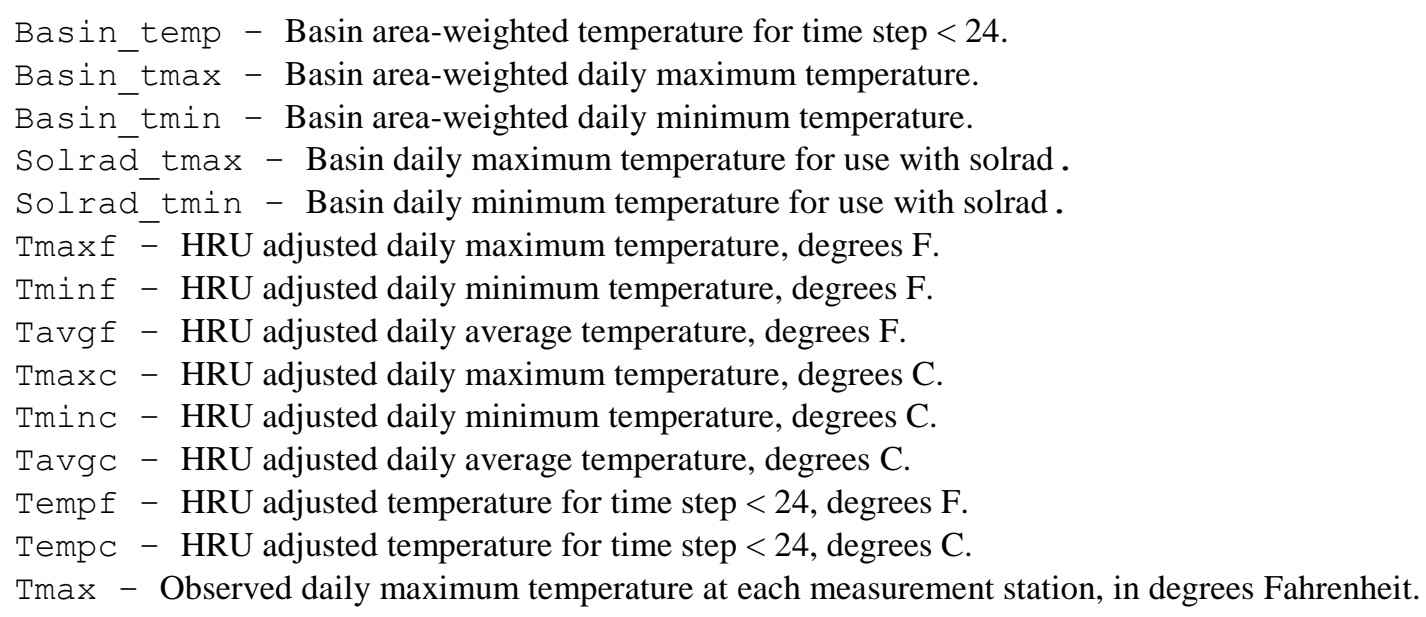


Tmin - Observed daily minimum temperature at each measurement station, in degrees Fahrenheit.

Newsnow - New snow on HRU ( $0=$ no; $1=$ yes $)$.

Pptmix - Precipitation mixture ( $0=$ no; $1=$ yes $)$.

Basin_ppt - Area weighted adjusted average precipitation for basin, in inches.

Basin_obs_ppt - Area weighted measured average precipitation for basin, in inches.

Basin_rain - Area weighted adjusted average rain for basin, in inches.

Basin_snow - Area weighted adjusted average snow for basin, in inches.

Hru_ppt - Adjusted precipitation on each HRU, in inches.

Hru_rain - Computed rain on each HRU, in inches.

Hru_snow - Computed snow on each HRU, in inches.

Prmx - Proportion of rain in a mixed event, in inches.

\section{EXTERNAL VARIABLES USED}

Route_on - Simulate flow routing $(0=$ no; $1=$ yes $)$.

Newday - Time step is first time step for a day $(0=$ no; $1=y e s)$.

Active_hrus - Number of active HRUs.

Hru_route_order - Routing order of HRUs.

Basin_area_inv - Inverse of total basin area as sum of HRU areas, in acres ${ }^{-1}$.

\section{DESCRIPTION}

This module reads daily and hourly precipitation and temperature data by HRU and makes that data available to other modules. Input data file names are hardcoded in the module.

\section{REFERENCES}

none

\section{DEVELOPER NAME AND ADDRESS}

\section{R. Steve Regan}

U.S. Geological Survey

Box 25046, MS 412

Denver Federal Center

Lakewood, CO 80225 


\section{Module local_flow_drbc.f}

\section{NAME}

local_flow_drbc.f

\section{SPECIAL FEATURES}

This is a new module.

\section{MODULE PROCESS (TYPE)}

Output

\section{DEFINITION}

Accumulates and outputs flows for calibration and use by other models.

\section{KEYWORDS}

\section{CREATION DATE}

January 2009

\section{PARAMETERS DECLARED}

Hru area - Area of each HRU.

Dss_output_file - Name of DSS output file.

Csv_output_file - Name of comma-delimited output file.

\section{VARIABLES DECLARED}

Locs - Output identifiers for DSS output.

Loc_flows - Accumulated flows for DSS output.

Strm_flows - Storm mode flows for calibration output.

Ifltab - File identifier for DSS file.

Nowtime - Time formatted for DSS file.

Jul_day - Julian day.

Ierr - Error flag for DSS output process.

Nsegment - Number of output segments for DSS file.

Cpath - Path identifier for DSS output.

$\mathrm{Ca}-\mathrm{f}$ - Identifiers (DSS "part”) A through F for DSS output.

\section{EXTERNAL VARIABLES USED}

Route_on - Simulate flow routing ( $0=$ no; $1=y e s)$.

Sub_c $\bar{f} s$ - Subbasin flow (cfs).

Sub_inq - Instantaneous subbasin flow (cfs).

Hru_ppt - Precipitation on HRU (inch).

Runoff - Observed gage flow (cfs) 
Q_chan - Flow at outlet of channel (cfs).

Qinlat_chan_ts - Time step lateral inflow to channel (cfs).

Q_chan_timestep - Time step flow at outlet of channel (cfs).

Qin_instant - Instantaneous flow at inlet of channel (cfs).

Contrib_area_chan - Channel contributing drainage area (acres).

Hortonian_lakes - Hortonian runoff to lake HRU (cfs).

Strm_seg_in - Index of stream segments that flow to current segment.

Lakein_sz - Soil zone runoff to lake HRU (cfs).

Lakein_gw - Groundwater runoff to lake HRU (cfs).

\section{DESCRIPTION}

This module accumulates flows for calibration and use by other models. Calibration values use observed reservoir outflows instead of simulated reservoir outflows because reservoirs are not simulated in the present model. Reservoir inflows, local runoff, and tributary flows are output to a HEC-DSS format file for use in a separate reservoir simulation and downstream flow routing model using HECResSim. Flow accumulations, output identifiers, and file names are hardcoded in the module.

\section{REFERENCES}

U.S. Army Corps of Engineers, Hydrologic Engineering Center, 2006, HEC-DSSVue, HEC Data storage system visual utility engine, User's manual version 1.2 revised [online]: accessed December 3, 2008, at http://www.hec.usace.army.mil/software/hec-dss/documents/CompleteManual.pdf.

U.S. Army Corps of Engineers, Hydrologic Engineering Center, 2007, HEC-ResSim Reservoir simulation system, User's manual version 3.0 [online]: accessed December 3, 2008, at http://www.hec.usace.army.mil/software/hec-ressim/documentation/HEC-

ResSim_30_UsersManual.pdf.

\section{DEVELOPER NAME AND ADDRESS}

R. Steve Regan

U.S. Geological Survey

Box 25046, MS 412

Denver Federal Center

Lakewood, CO 80225 


\section{Module snow17_st.f}

\section{NAME}

snow17 st.f

\section{SPECIAL FEATURES}

This is a port of the existing SNOW-17 algorithm to PRMS. No changes were made to the algorithm or existing code.

\section{MODULE PROCESS (TYPE)}

Snow

\section{DEFINITION}

Snow accumulation and ablation model.

\section{KEYWORDS}

\section{CREATION DATE}

January 2009

\section{PARAMETERS DECLARED}

SCF - The multiplying factor which adjusts precipitation that is determined to be in the form of snow. SCF primarily accounts for gage catch deficiencies, but also implicitly includes the net effect of vapor transfer (sublimation and condensation, including from intercepted and blowing snow) and transfers across areal divides.

MFMAX - Maximum melt factor during non-rain periods - assumed to occur on June $21 \mathrm{st}\left(\mathrm{mm} \bullet{ }^{\circ} \mathrm{C}-1 \bullet 6 \mathrm{hr}-1\right)$.

MFMIN - Minimum melt factor during non-rain periods - assumed to occur on December $21 \mathrm{st}\left(\mathrm{mm} \cdot{ }^{\circ} \mathrm{C}-1 \bullet 6 \mathrm{hr}-1\right)$.

UADJ - The average wind function during rain-on-snow periods $(\mathrm{mm} \bullet \mathrm{mb}-1)$. UADJ is only a major parameter when there are fairly frequent rain-on-snow events with relatively warm temperatures.

SI - The mean areal water equivalent above which there is always 100 percent areal snow cover $(\mathrm{mm})$. SI is not a major parameter when the model is applied at a point location or when significant bare ground appears soon after melt begins no matter the magnitude of the snow cover.

Area Depletion Curve - Curve that defines the areal extent of the snow cover as a function of how much of the original snow cover remains after significant bare ground shows up. The areal depletion curve also implicitly accounts for the reduction in the mean areal melt rate that occurs as less of the area is covered by snow. Generally not needed for a point location.

$\mathrm{NMF}$ - Maximum negative melt factor $\left(\mathrm{mm} \cdot{ }^{\circ} \mathrm{C}-1 \cdot 6 \mathrm{hr}-1\right)$. The negative melt factor has the same seasonal variation as the non-rain melt factor, thus the maximum value is assumed to occur on June 21 st.

TIPM - Antecedent temperature index parameter (real - range is 0.01 to 1.0). Controls how much weight is put on temperatures from previous time intervals when computing ATI. The smaller the value of TIPM, the more previous time intervals are weighted.

PXTEMP - The temperature that separates rain from snow $\left({ }^{\circ} \mathrm{C}\right)$. If the air temperature is less than or equal to PXTEMP, the precipitation is assumed to be in the form of snow. The PXTEMP parameter, as defined for SNOW-17, is not used if a rain-snow elevation time series is used to determine the form of precipitation.

MBASE - Base temperature for snowmelt computations during non-rain periods $\left({ }^{\circ} \mathrm{C}\right)$. Typically a value of $0^{\circ} \mathrm{C}$ is used. 
PLWHC - Percent liquid water holding capacity (decimal fraction). Indicates the maximum amount of liquid water, as a fraction of the ice portion of the snow, that can be held against gravity drainage (maximum allowed value is 0.4 ).

DAYGM - Constant daily amount of melt which takes place at the snow-soil interface whenever there is a snow cover (mm•day-1).

\section{VARIABLES DECLARED}

WE - Water equivalent of ice portion of snow cover (mm).

NEGHS - Heat deficit (mm).

LIQW - Liquid water held by the snow (mm).

TINDEX - Antecedent temperature index $\left({ }^{\circ} \mathrm{C}\right)$.

ACCMAX - Maximum amount of water equivalent that existed during accumulation period ( $\mathrm{mm}$ ).

SB - Water equivalent when new snowfall first occurs on a partly bare area $(\mathrm{mm})$.

SBAESC - Areal cover when new snowfall occurs on a partly bare area (decimal fraction).

SBWS - Water equivalent where the areal cover drops below 100\% when melt occurs after new snowfall takes place on a partially bare area $(\mathrm{mm})$.

STORGE - Lagged excess liquid water in storage (mm).

AEADJ - Areal index value computed for use in depletion curve computations after an adjustment to the areal extent of snow cover $(\mathrm{mm})$.

EXLAG (7) - Average hourly lagged excess water for each precipitation time interval (mm).

SNDPT - Snow depth (cm).

SNTMP - Snow cover temperature $\left({ }^{\circ} \mathrm{C}\right)$.

\section{EXTERNAL VARIABLES USED}

\section{DESCRIPTION}

This module does hourly snow accumulation and ablation.

\section{REFERENCES}

Anderson, E.A., 2006, Snow accumulation and ablation model - SNOW-17-Chap. II.2 of NOAA's NWS River Forecast System User Manual [online]: accessed November 18, 2008, at http://www.weather.gov/oh/hrl//nwsrfs/users_manual/part2/_pdf/22snow17.pdf.

\section{DEVELOPER NAME AND ADDRESS}

R. Steve Regan

U.S. Geological Survey

Box 25046, MS 412

Denver Federal Center

Lakewood, CO 80225 
For more information concerning this publication contact:

Director

USGS Pennsylvania Water Science Center

215 Limekiln Road

New Cumberland, Pennsylvania 17070

dc_pa@usgs.gov

The latest version of the model and this report can be obtained using the Internet address:

http://pa.water.usgs.gov/drbfam

Published in the Eastern Region, New Cumberland, Pa.

Manuscript approved for publication, January 22, 2010

Edited by Kim L. Otto 
